\title{
Stratigraphic Revision of Upper Miocene and Lower Pliocene Beds of the Chesapeake Group, Middle Atlantic Coastal Plain
}

GEOLOG I CALSURVEY B ULLETIN 1482-D

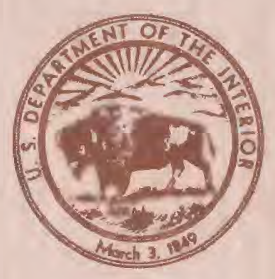





\section{Stratigraphic Revision of Upper Miocene and Lower Pliocene Beds of the Chesapeake Group, Middle Atlantic Coastal Plain}

By LAUCK W. WARD and BLAKE W. BLACKWELDER CONTRIBUTIONS TO STRATIGRAPHY

G E O L O G I C A L S U R V E Y B U L L E T I N 1482 - D

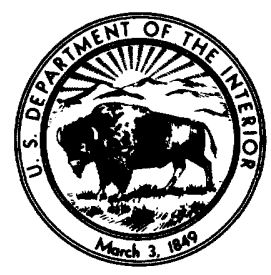




\title{
UNITED STATES DEPARTMENT OF THE INTERIOR
}

\author{
GECIL D. ANDRUS, Secretary
}

GEOLOGICAL SURVEY

H. William Menard Director

\section{Library of Congress Cataloging in Publication Data}

Ward, Lauck W

Stratigraphic revision of upper Miocene and lower Pliocene beds of the Chesapeake group-middle Atlantic Coastal Plain.

(Contributions to stratigraphy) (Geological Survey bulletin ; 1482-D)

Bibliography: $p$.

Supt. of Docs. no. : I 19.3:1482-D

1. Geology, Stratigraphic-Miocene. 2. Geology, Stratigraphic-Pliocene. 3. GeologyMiddle Atlantic States. I. Blackwelder, Blake W., joint author. II. Title. III. Series. IV. Series: United States.

Geological Survey. Bulletin ; 1482-D.

QE694.W37 551.7'87'0975 80-607052

For sale by Superintendent of Documents, U.S. Government Printing Office Washington, D.C. 20402 


\section{CONTENTS}

$\begin{array}{cr}\text { Abstract } & \text { Page } \\ \text { Introduction } & \text { D1 } \\ \text { Acknowledgments } & 1 \\ \text { Discussion } & 4 \\ \text { Chronology of depositional events } & 4 \\ \text { Miocene Series } & 7 \\ \text { Eastover Formation } & 8 \\ \text { Definition and description } & 8 \\ \text { Stratigraphic relationships } & 12 \\ \text { Claremont Manor Member } & 19 \\ \text { Cobham Bay Member } & 28 \\ & 28 \\ \text { Pliocene Series } & 28 \\ \text { Yorktown Formation } & 29 \\ \text { Previous work } & 31 \\ \text { Redefinition and description } & 31 \\ \text { Stratigraphic relationships } & 32 \\ \text { Paleogeography } & 32 \\ \text { Age and correlation } & 36 \\ \text { Paleoenvironment } & 40 \\ \text { Sunken Meadow Member } & 43 \\ \text { Rushmere Member } & 48 \\ \text { Morgarts Beach Member } & 54 \\ \text { Moore House Member } & 60\end{array}$

\section{ILLUSTRATIONS}

[Plates follow "References Cited"]

Plate 1. Mollusks from the Claremont Manor Member.

2. Mollusks from the Cobham Bay Member.

3. Mollusks from the Cobham Bay Member.

4. Mollusks from the Sunken Meadow Member.

5. Mollusks from the Rushmere, Morgarts Beach and Moore House Members. 
Figure 1. Selected outcrops that are listed in the "Locality Register"

2. Correlation chart showing stratigraphic relationship of the members of the Eastover and Yorktown Formations

3. Location of type section of the Eastover Formation

4. Type locality of Eastover Formation

5. Location of the type section of the Claremont Manor Member of the Eastover Formation and the Sunken Meadow Member of the Yorktown Formation

6. Type locality of the Claremont Manor Member, Eastover Formation, and of the Sunken Meadow Member, Yorktown Formation

7. Basin configuration of the Claremont Manor Member, Eastover Formation

8. Location of the type section of the Cobham Bay Member, Eastover Formation

9. Type locality of the Cobham Bay Member, Eastover Formation

10. Basin configuration of the Cobham Bay Member, Eastover Formation

11. Yorktown Formation overlying laminated clays of the Eastover Formation

12. Piankatank River, Va., near Martiau showing shelly beds of the Sunken Meadow Member

13. Extent of outcrops of the Sunken Meadow Member of the Yorktown Formation

14. Location of Yorktown Formation lectostratotype near Rushmere, Isle of Wight Co., Va. Type locality of the Rushmere Member

15. Lectostratotype of the Yorktown Formation and type locality of the Rushmere Member

16. Extent of outcrops of the Rushmere and Morgarts Beach Members of the Yorktown Formation

17. Location of the type section of the Morgarts Beach Member, Yorktown Formation

18. Type locality of the Morgarts Beach Member

19. Location of the type section of the Moore House Member, Yorktown Formation

20. Type locality of the Moore House Member

21. Extent of outcrops of the Moore House Member of the Yorktown Formation

22. Schematic sections along major Virginia rivers

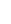

17

23. View of the cliffs just below Wilmont Wharf on the Rappahannock River

24. Location of structural features in part of the Virginia Coastal Plain

25. View of the cliffs at Burhans Wharf on the Rappahannock River 


\title{
STRATIGRAPHIC REVISION OF UPPER MIOCENE AND LOWER PLIOCENE BEDS OF THE CHESAPEAKE GROUP, MIDDLE ATLANTIC COASTAL PLAIN
}

\author{
By LAUCK W. WARD and BLAKE W. BLACKWELDER
}

\begin{abstract}
The Eastover Formation, a newly recognized upper Miocene marine unit within the Chesapeake Group, is herein named and described. The Eastover Formation is divided into two members: a lower, burrowed, silty, fine-grained sand - the Claremont Manor Member - and an upper, shelly, finegrained sand - the Cobham Bay Member. The Eastover Formation extends from southern Maryland to North Carolina and as far inland as Richmond. Although beds of the Eastover Formation have previously been assigned to the Yorktown Formation, the Yorktown is a distinct unit that can be divided into four members: the Sunken Meadow, Rushmere, Morgarts Beach, and Moore House. Sediments assigned to the Eastover Formation have also been assigned erroneously to the Calvert, Choptank, and St. Marys Formations.
\end{abstract}

\section{INTRODUCTION}

The Eastover Formation is herein named and described for a 5- to 28-m-thick sequence of upper Miocene sediments underlying the Coastal Plain of Virginia and the adjacent areas of North Carolina and Maryland (fig. 1). Some sediments previously included in the Calvert, Choptank, St. Marys, and Yorktown Formation (Clark and Miller, 1906, 1912; Olsson, 1917; Mansfield, 1928, 1931, 1943) are now included in the Eastover and Yorktown Formations. Although superficially resembling parts of the Calvert, Choptank, St. Marys, and Yorktown Formations, the Eastover Formation is a lithologically distinct assemblage of sediments occupying a unique depositional basin and containing a characteristic fossil assemblage. The Eastover Formation unconformably overlies Cretaceous, Paleocene, Eocene, Oligocene, and Miocene marine units as well as preMesozoic Piedmont metamorphic rocks. Contacts are sharp and 


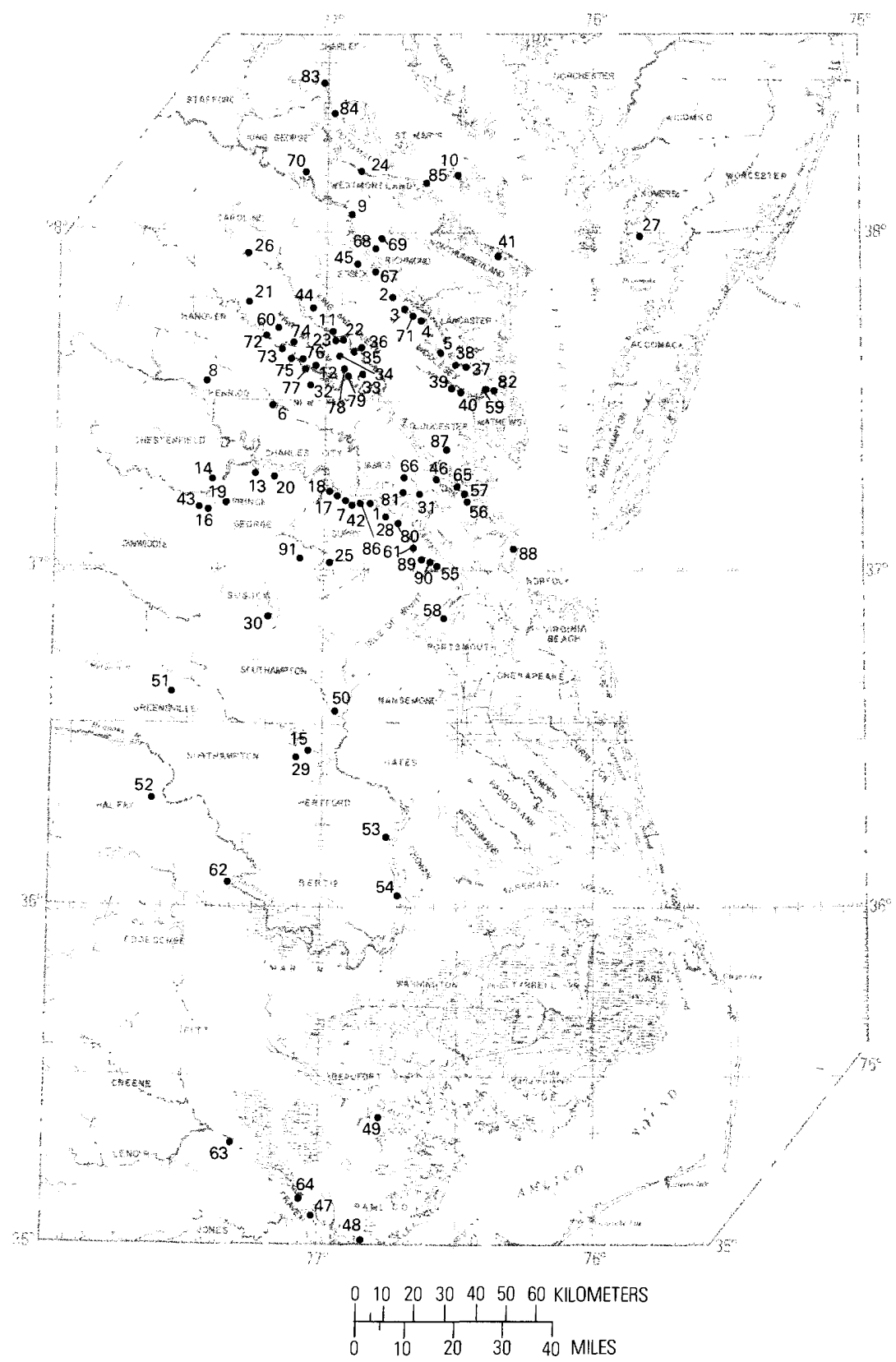

Figure 1.--Selected outcrops that are listed in the "Locality Register." 
well-defined. The Eastover Formation is $28 \mathrm{~m}$ thick in the Claremont area of Surry County, Va., and is approximately 5 to $10 \mathrm{~m}$ thick in exposures over much of its outcrop belt across the central Virginia Coastal Plain. The Eastover Formation is composed of a lower unit, the Claremont Manor Member that is a silty burrowed sand, and an upper unit, the Cobham Bay Member that is a shelly fine sand. These members of the Eastover Formation are of Tortonian (late Miocene) Age.

Some earlier workers (for example Clark and Miller, 1906, 1912; Gibson, 1970, 1971) included sediments of the Eastover Formation in the Yorktown Formation. Therefore, the Yorktown is redefined and divided into four members: the Sunken Meadow, Rushmere, Morgarts Beach, and Moore House Members. A correlation chart (fig. 2) shows the stratigraphic succession of these units. These formations, the Eastover and the Yorktown, are part of the Chesapeake Group.

\section{ACKNOWLEDGMENTS}

Appreciation is expressed to J. E. Hazel, N. F. Sohl, T. M. Cronin, and R. M. Forester, all of the U.S. Geological Survey, for technical assistance and help in the field. G. B. Lawrence and J. B. Green, Jr., Richmond, Va., C. H. Lee, University of South Carolina, S.C., Thor Hansen, Washington, D.C. and C. E. Mason, the George Washington University, Washington, D.C., assisted in various phases of field and laboratory work. C. E. Ray, Smithsonian Institution, provided valuable advice.

\section{DISCUSSION}

Early stratigraphic studies in Virginia included sediments, herein assigned to the Eastover Formation, within the "Appomattox" or "Lafayette" Formation. McGee (1888) placed the "orange-colored sands and clays" at Petersburg, Va., in his Appomattox Formation. In 1891, McGee rejected the name Appomattox and, with Darton (1891), revived the name Lafayette Formation. Later work showed that these orange sands, included earlier in the Appomattox Formation and later in the Lafayette Formation, were of various ages and represented the weathered residuum of many different marine units. The term Lafayette Formation has since been abandoned (Wilmarth, 1957, p. 1129).

Beds herein assigned to the Eastover Formation were placed in the Calvert, Choptank, St. Marys, or Yorktown Formations by Clark and Miller $(1906,1912)$. The exposure of the Eastover Formation below Bowlers Wharf on the Rappahannock River, Va. (loc. 2, fig. 1 of this report) was called Calvert (Clark and Miller, 1912, p. 135) and the sections listed 


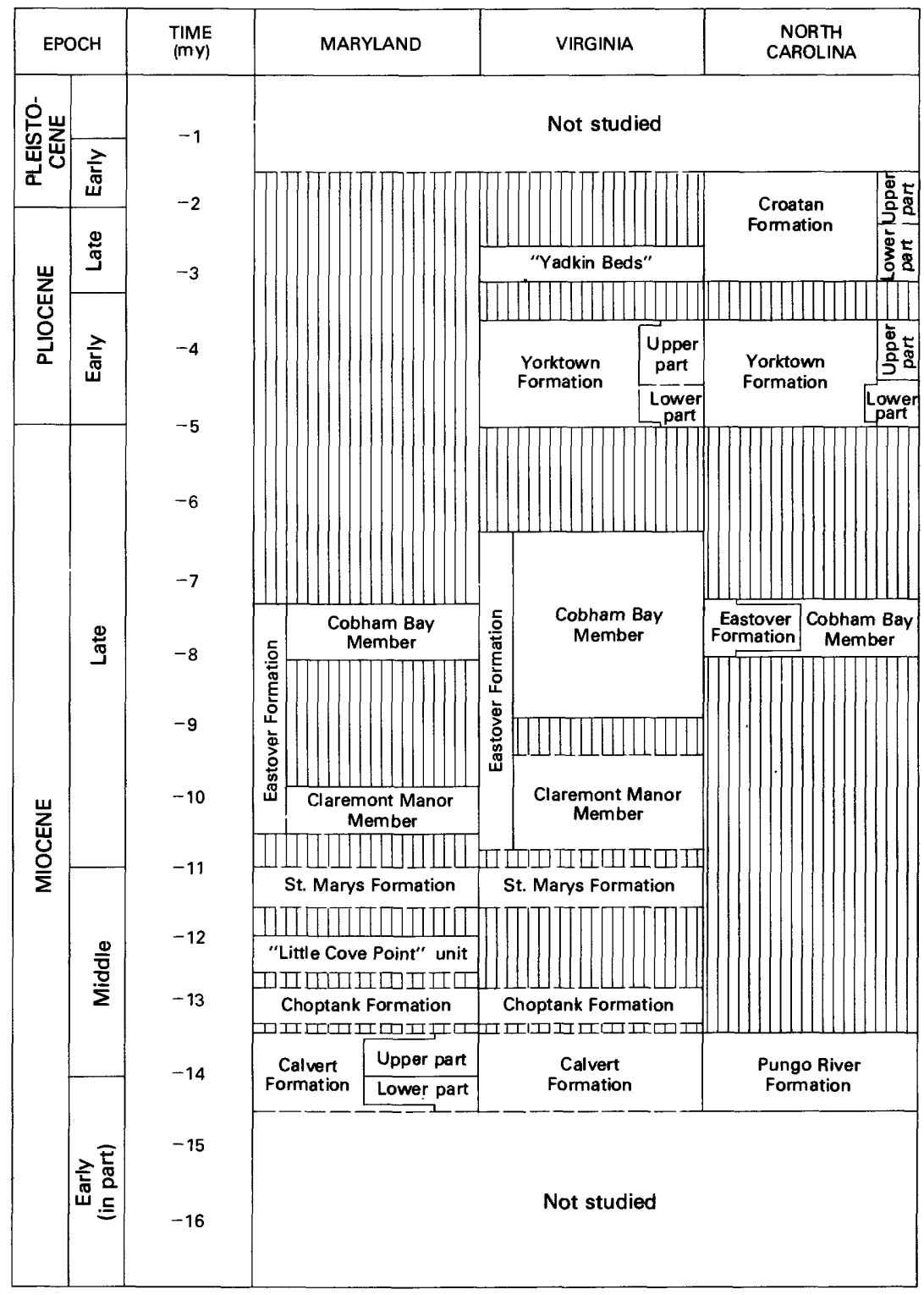

Figure 2.-Correlation chart showing stratigraphic relationship of the members of the Eastover and Yorktown Formations. The lower part of the Yorktown Formation consists of the Sunken Meadow Member and the upper part consists of the Rushmere, Morgarts Beach, and Moore House Members. The "Little Cover Point" unit is an informal unit recognized only in Maryland. On this chart, the Eastover Formation is represented by the Claremont Manor and the Cobham Bay Members. Age shown in millions of years. 
(1912, p. 143-145) from the Rappahannock River were assigned to the St. Marys Formation. Part of the section given for the Yorktown Formation at Yorktown, Va. (1912, p. 161), belongs to the Eastover Formation. This section was described in reverse stratigraphic order, and the oldest bed was listed first (1912, p. 161). This first bed mentioned belongs to the Eastover Formation. Clark and Miller also assigned a St. Marys age to the exposures of shell marl along the Blackwater River, Va.; this shell marl is herein placed in the Yorktown Formation. Although Clark and Miller named the Yorktown Formation, they assigned Yorktown sediments at Petersburg, Va. (1912, p. 139), to the Calvert Formation, apparently because they expected beds to the west to be progressively older than those to the east.

Olsson (1917) recognized that some sediments in southeastern Virginia and northeastern North Carolina were older than Yorktown and younger than St. Marys. For these intermediate-age beds he introduced the term "Murfreesboro stage." Olsson listed five localities where sediments of his Murfreesboro cropped out. In this list, the Miocene at Murfreesboro, N.C., was included $(1917$, p. 156). Field work by the present authors showed that the Cobham Bay Member of the Eastover Formation and the Yorktown Formation (Sunken Meadow, Rushmere, and Morgarts Beach Members) are present at that locality. The Pamunkey River near West Point, Va., was also listed (1917, p. 156) as a Murfreesboro locality. The exposures there are herein assigned to the Eastover Formation (Claremont Manor and Cobham Bay Members). Beds of blue clay (along the James River) herein considered to be Yorktown Formation, were assigned to the Murfreesboro by Olsson (1917, p. 157). Beds exposed at Petersburg, Va., were placed in the Murfreesboro (1917, p. 157), but, as mentioned above, these beds are referable to the Yorktown Formation. In North Carolina, beds that can be correlated with the Yorktown Formation were placed in the St. Marys Formation by Clark and Miller (1912) and later assigned by Olsson (1917, p. 158) to the Murfreesboro. Mansfield (1928) suggested that the term Murfreesboro may not be available as a rock stratigraphic term because of the Murfreesboro Limestone in Tennessee.

On the basis of the molluscan assemblage, Mansfield $(1928$, p. 2) concluded that Olsson's Murfreesboro Stage belonged to the lower part of the Yorktown Formation. In 1931, Mansfield (p. 94) recognized two faunal horizons at the type locality of the "Murfreesboro stage" and assigned the lower unit to his zone 1 of the Yorktown and the other to zone 2 of the Yorktown. Mansfield (1928) proposed a stratigraphic scheme for the Virginia Coastal Plain in which sediments, now included in the Eastover Formation, were placed in the St. Marys Formation. Mansfield (1931) provided a more detailed 
stratigraphic outline including a description of the lithology, distribution, and fossils of the St. Marys and Yorktown Formations. All the localities that Mansfield called Stratum A, Zone 1 and Zone 2 of the St. Marys belong to the Eastover Formation.

The Mt. Folly Formation of Weems (1968) is not adequately defined as a lithostratigraphic unit and includes parts of several different formations. The Mt. Folly is based on "yellow sand" at a leached marine section in which the lower boundary is placed at a change to less weathered material, and the upper part apparently includes beds belonging to the Yorktown Formation. Mt. Folly on the York River is only $5 \mathrm{~km}$ ( 8 miles) below West Point, whereas the section given by Weems $(1968$, p. 15$)$ is stated to be "twenty miles below West Point," which would place it near Yorktown, Va. We propose that the name "Mt. Folly Formation" be rejected for the above reasons.

Johnson (1969) recognized two distinct lithologies in the St. Marys Formation (Eastover Formation of this report). The "lowermost beds of the St. Marys" were called the "silty sand" in Johnson's figure 5 and the "uppermost beds of the St. Marys" were called the "sandy shell" unit. These units correspond to the Claremont Manor and Cobham Bay Members of the Eastover Formation.

Gibson (1970) described basin migration and formational distribution of the Miocene and Pliocene from New Jersey to North Carolina. His isopach map of the St. Marys Formation (1970, fig. 5) showed limited St. Marys deposition south of the Potomac River. Later, Gibson (1971, p. 12) indicated that "no unquestionable pockets of strata of Maryland St. Marys age are found in Virginia." He concluded that the St. Marys Formation is virtually absent south of the Potomac River. However Gibson's (1975, fig. 5) stratigraphic chart indicates the presence of the St. Marys in both Maryland and Virginia.

Teifke (1973), in an attempt to establish a rockstratigraphic framework for the Virginia Coastal Plain, included all beds above the Calvert Formation and below the Columbia Group Pleistocene within the Yorktown Formation.

A consistent stratigraphic framework is obviously lacking for upper Miocene and lower Pliocene beds underlying the Virginia Coastal Plain. Early work by Clark and Miller (1912), Olsson (1917), and Mansfield (1928, 1931, 1943) showed a confusing mixture of lithostratigraphic, chronostratigraphic, and biostratigraphic units and more modern work has failed to eliminate the confusion.

Because of the general similarity of these clastic deposits, the first inclination is to group the various units together. However, such a grouping obscures the regional geologic history. Study of outcrops, quarries, and drill data, 
together with biostratigraphic research, has resulted in the recognition of several new units. Lithologic differences, although subtle in places, are persistent, and the lateral as well as vertical expressions of the formations are discernible. Mapping of lower and upper contacts reveals that each of the named units occupies a unique basin. This paper describes these extensive, mostly fossiliferous, marine units deposited during late Miocene and early Pliocene time. On the margins of these basins, gravel beds were deposited which, in some places, may be related to particular marine sequences. Over most of the study region, marine units overlie marine units and no beds of intervening fluvial gravel are present.

\section{CHRONOLOGY OF DEPOSITIONAL EVENTS}

After a brief marine transgression during the late Oligocene (unnamed unit), the Maryland and Virginia Coastal Plain became emergent until the middle part of the early Miocene. At this time, a series of marine transgressions began in Maryland and Virginia that were to leave a relatively complete stratigraphic record through the early Pliocene. Lower and middle Miocene lagoonal and shallow shelf deposits (Calvert and Choptank Formations) stretch from the Eastern Shore of Maryland south to Richmond, Va. In the middle Miocene, a series of small embayments occupied the southeastern corner of Maryland while the Virginia Coastal Plain was largely emergent. From late middle to early late Miocene time, deposition shifted southward to the Rappahannock River area in Virginia. The transgression resulted in accumulation of fine shelly sand of the St. Marys Formation in northeastern Virginia and southeastern Maryland. During the late Miocene, marine sedimentation was virtually terminated in Maryland, except in small areas where the Claremont Manor and Cobham Bay seas overlapped that section. Sedimentation continued in Virginia throughout the late Miocene, and the Claremont Manor sea covered the northern two-thirds of the Coastal Plain. The later Coham Bay sea overlapped slightly into Maryland and North Carolina.

In early Pliocene time the Yorktown sea covered eastern Virginia, and large numbers of warm temperate mollusks flourished. During maximum transgression, the Yorktown sea transgressed older post-Paleozoic sediments onto the Piedmont. Regressive sediments of the late Yorktown sea occupy only a small area in southeastern Virginia.

The Eastover and Yorktown Formations are considered to belong to the Chesapeake Group. The name "Chesapeake Formation" was originally proposed for strata of Miocene age by Darton (1891). Dall (1892) changed Darton's term to 
"Chesapeake Group" and included all the rocks of Miocene age from the Chesapeake Bay area to Florida. Rocks in Florida and Georgia subsequently were omitted from the Chesapeake Group.

The Yorktown Formation of Virginia and North Carolina was also placed in the Chesapeake Group by these early workers and was considered to be of Miocene age. The Yorktown Formation is closely related to the same series of events and geographical controls influencing the deposition of the other formations. It is herein retained in the Chesapeake Group. However, various evidence leads to the conclusion that the Yorktown is entirely of early Pliocene age. (J. E. Hazel, written commun. 1977).

The Eastover Formation is related to similar depositional conditions and basins, such as those in the Yorktown and earlier St. Marys deposits, and it is also considered part of the Chesapeake Group.

Also included in the Chesapeake Group are the deposits of the Chowan River Formation (upper Pliocene). The Chowan River is found in southeasternmost Virginia and in North Carolina. Basin configuration suggests that this was the last of the large inland basins that had been present almost continuously since early Miocene time. Chowan River molluscan assemblages represent the last occurrence of many elements common in earlier Chesapeake Group assemblages and indicate that the Chowan River was one of the last of the warm temperate seas to inundate major parts of the eastern Atlantic Coastal Plain. Deposits of the Chowan River are, in part, lithically very similar to other units in the Chesapeake Group.

\section{MIOCENE SERIES}

\section{EASTOVER FORMATION}

\section{Definition And Description}

The Eastover Formation is named for a series of beds of silty sand, clay, and shelly fine sand in the Maryland, Virginia, and North Carolina Coastal Plain. This formation is well exposed at the type locality along the right bank of the James River near Eastover, Surry County, Va., loc. 1 (fig. 3 and 4). It is divided into two members. The lower member, the Claremont Manor, consists of greenish-gray (5Y5/2) (Goddard, 1948), finegrained clayey sand or sandy clay. The sand-sized fraction is typically glauconitic (usually 5 percent or less) and poorly sorted; fine-grained mica is rare. The overlying Cobham Bay Member consists of units of fine-grained, well-sorted, shelly sand. The Eastover Formation differs from the underlying St. 

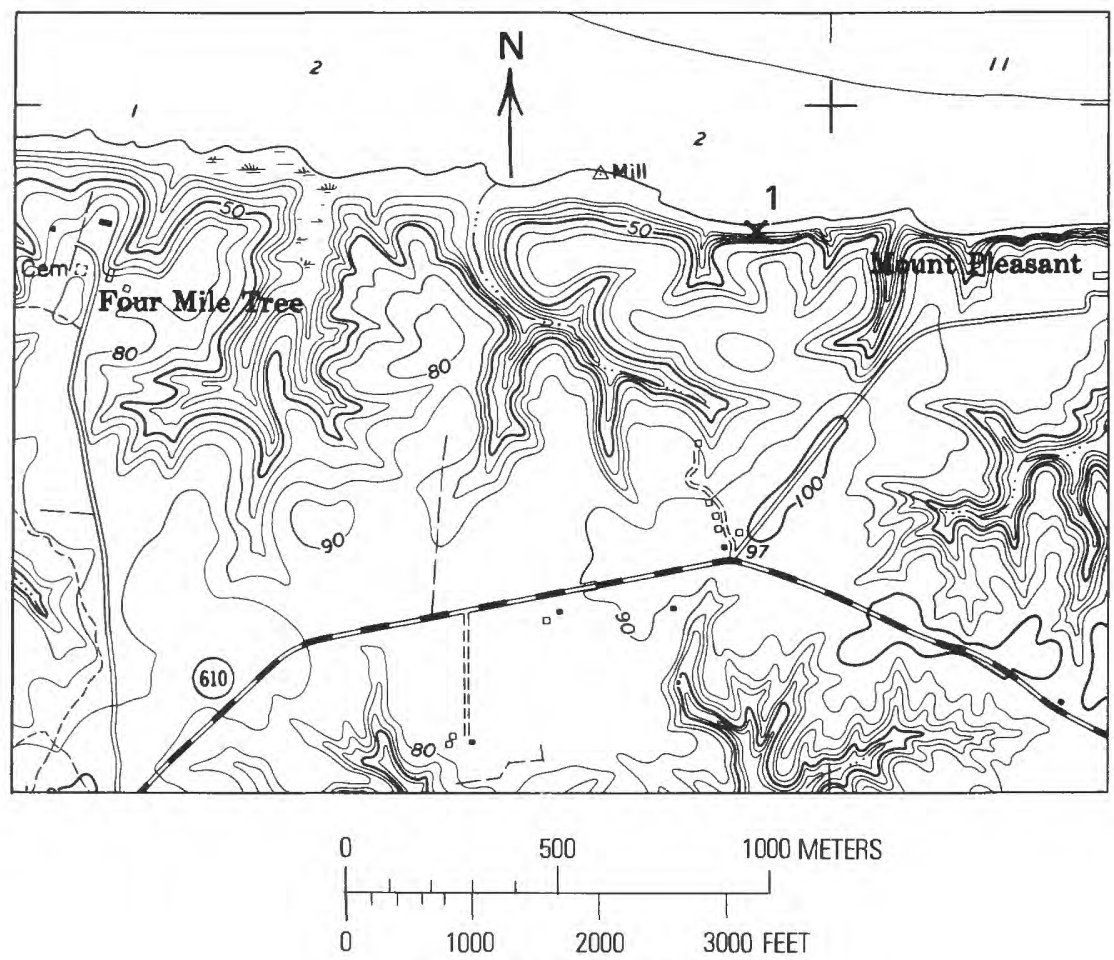

CONTOUR INTERVAL 10 FEET

NATIONAL GEODETIC VERTICAL DATUM OF 1929

DEPTH CURVES IN FEET-DATUM IS MEAN LOWER LOW WATER

SHORELINE SHOWN REPRESENTS THE APPROXIMATE LINE OF MEAN HIGH WATER

Figure 3.--Location of type section of the Eastover Formation, Claremont and Surry quads., Va.

Marys in that the sand fraction in the parts lower of the Eastover are generally less well sorted and lower parts of the Eastover are diatomaceous. In addition, deposits of the St. Marys Formation, particularly in Virginia, contain abundant mollusks that thrived in the well-sorted, fine silty sand.

Locality 1. Type section of the Eastover Formation, $5.1 \mathrm{~km}$ east of Eastover; measured $0.8 \mathrm{~km}$ above Mount Pleasant, right bank of the James River, (Surry County, Va.). (Surry 7 1/2-min. quad.1965)

\section{Pleistocene(?)}

Thickness (m)

Orange sand and gravel $\ldots \ldots \ldots \ldots \ldots \ldots . \ldots$ 


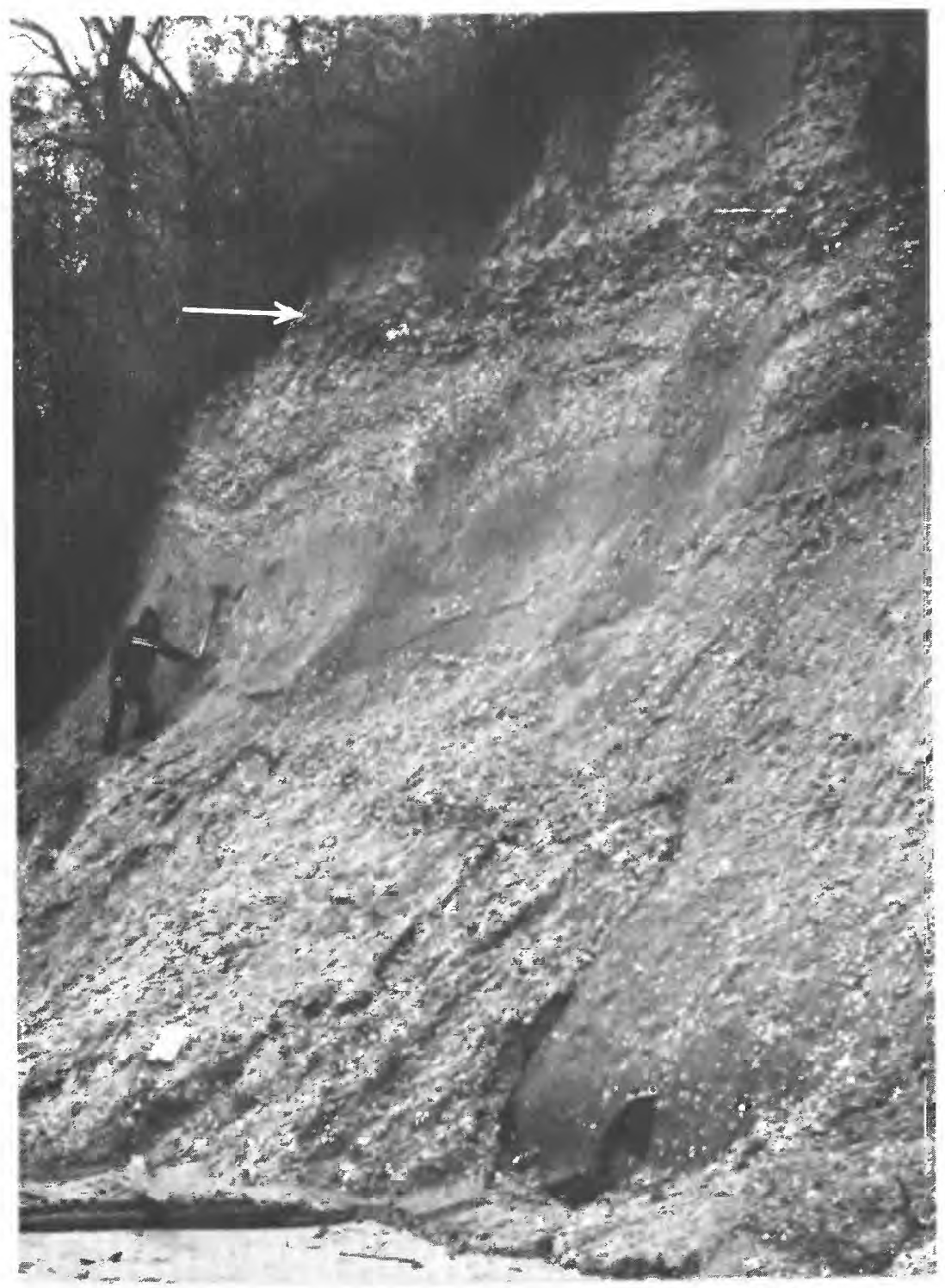

Figure 4.--Type locality of Eastover Formation showing silty Claremont Manor Member overlain by shelly Cobham Bay Member.

Pleis tocene(?)--Cont inued Yorktown Formation Rushmere Member Tan shelly fine sand $\ldots \ldots \ldots \ldots \ldots 2.0$ 
Sunken Meadow Member

Tan, moderately sorted, phosphatic,

glauconitic, shelly sand; bedding

obscured by large volume of bivalves

(mostly Chesapecten).

Lower contact ................. 2.0

Eastover Formation

Cobham Bay Member

Tan fine shelly sand. Bivalves

abundant and dominated by

Chesapecten and Isognomon. Massive shell

bed showing some bedding; lower contact

undulating and, in areas, cutting across

shell bands of the Claremont Manor . . . . . 2.0

Claremont Manor Member

Greenish-gray, poorly sorted, fine silty

sand that is weathered to light $\tan$ in

the upper half. Mollusks fairly abundant

but concentrated in thin shell ......... 5.0

- Approximate mean low-tide level-_

The Eastover differs from the overlying Yorktown by the presence of pearlaceous bivalves (Isognomon) in the silty, shelly sand of the upper part of the Eastover. They also differ in the presence of the better sorted shelly fine sand in much of the Yorktown. Where the Yorktown overlies the lower member of the Eastover, lithologic differences are very pronounced because the lower member is very clayey, not as well-sorted, and tends to lack the abundant shells of the Yorktown. Lithologies vary over the large area that these basins occupy, but at most localities, lithologic differences between formations are very apparent. Contacts between units are very sharp and many are marked by phosphate, bone, and burrowing of the older units. Regionally, some contacts indicate angular unconformities.

The dip of the Eastover varies locally according to underlying structural conditions. Along the Rappahannock River, in the vicinity of Bowlers Wharf (loc. 2) and Laytons Landing (loc. 3), Essex County, Va., the Eastover dips to the northwest (upriver) at a rate of $2 \mathrm{~m} / \mathrm{km}$. From Bayport (loc. 4) to Urbanna (loc. 5), Middlesex County, Va., the Eastover resumes the normal seaward dip at a rate of about $0.6 \mathrm{~m} / \mathrm{km}$. These structural anomalies, that locally affect the dip, also affect the formation's thickness. In the vicinity of Bottoms Bridge, New Kent County, Va. (loc. 6), the Eastover Formation is only $6 \mathrm{~m}$ thick, whereas to the southeast at Claremont (loc. 7) it is $24 \mathrm{~m}$ thick, and to the west at Richmond, Va., (loc. 8) it is $14 \mathrm{~m}$ thick. The Eastover Formation is considered to be late Miocene in age and correlates with the Tortonian Stage in Europe. 


\section{Stratigraphic Relationships}

In the outcrop area, the Eastover Formation overlies progressively older sediments from north to south. In the Potomac River area it overlies the Choptank Formation (loc. 24) and St. Marys Formation (loc. 10). South of this, along the Mattaponi River (loc. 11) and Pamunkey River, Va., (loc. 12) it overlies the Calvert Formation. Farther south, the Eastover overlies upper Oligocene sands which crop out along the Chickahominy River (loc. 6). Near Hopewell, Va. (loc. 13, 20), the Eastover Formation overlies beds of the Nanjemoy Formation (lower and middle Eocene). At Colonial Heights, Va. (loc. 14), the Eastover overlies Cretaceous sandstone. Near Murfreesboro, N.C. (loc. 15), the Eastover overlies Cretaceous clayey sand. These relationships are discussed in the description of the two members. In the western half of the Eastover basin, sediments are considerably more clayey, and in some areas, near Richmond (loc. 8) and Petersburg (loc. 16), diatomaceous clays were deposited. In the eastern and central parts of the Eastover basin, both members become increasingly sandy, which makes their lithologic separation difficult, even though the contact between them is sharp.

Evidence for subsurface flexures may be found in the irregular depositional patterns within the Eastover basin. During the Claremont Manor transgression, a thick $(24 \mathrm{~m})$ sequence of silty sands and clays was deposited in the Claremont area (loc. 7). After the Claremont Manor regression, the area was locally uplifted so that the Cobham Bay sea apparently deposited only a thin bed in this area, while at the same time thicker beds were deposited to the east, west, and north. The Claremont area was still positive during the Yorktown transgression and in some areas the Cobham Bay Member was removed by erosion so that the Yorktown lies directly on the Claremont Manor (loc. 17).

\section{Claremont Manor Member}

Definition and Description.- The Claremont Manor Member is named for the extensive exposures along the James River below Upper Chippokes Creek near Claremont Manor. The type locality is $1.3 \mathrm{~km}$ below the mouth of Sunken Meadow Creek, Surry County, Va. (loc. 42) (fig. 5, 6). The Claremont Manor consists of beds of poorly sorted, coarse to fine, silty and clayey sand that fine upward in many areas to clay. These clay sequences generally mark the perimeter of the Claremont Manor basin; toward the center or eastern parts of the basin the sand content increases. Where fresh, most of these beds are 

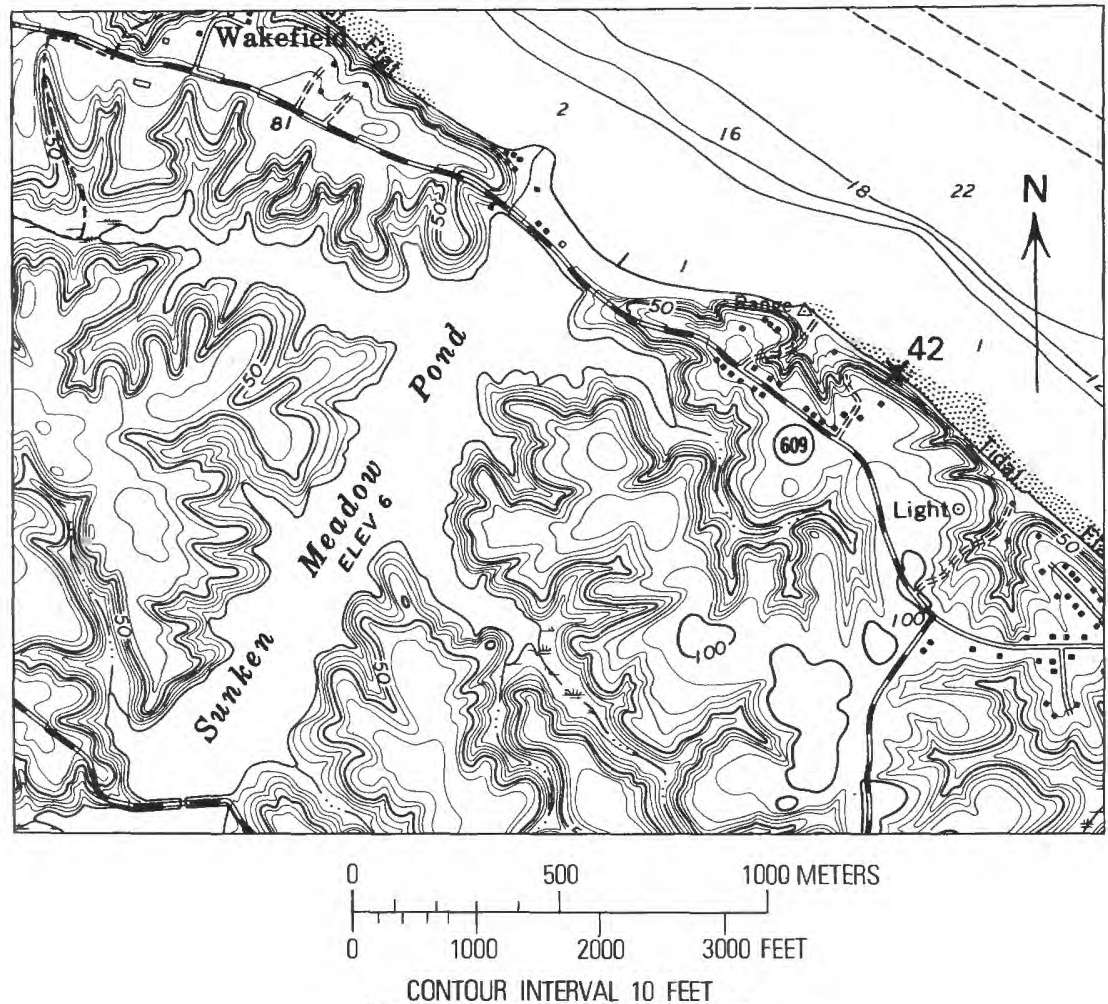

NATIONAL GEDDERIC VERTILAL DATUM OF 1929

DEPTH CURVES IN FEET-DATUM IS MEAN LOWER LOW WATER

SHORELINE SHOWN REPRESENTS THE APPROXIMATE UINE OF MEAN HIGH WATER

Figure 5.-Location of the type section of the Claremont Manor Member of the Eastover Formation and the Sunken Meadow Member of the Yorktown Formation. (Claremont 7.5-min quad.).

greenish-gray (5 YR 5/2) (Goddard, 1948), but weather to an ironstained tan (10 YR 8/6). The Claremont Manor transgression covered much of the Virginia Coastal Plain and overlapped slightly into southeastern Maryland. The thickest known sequence of Claremont Manor is at Claremont (loc. 7) where 24 $\mathrm{m}$ occur in the subsurface and in outcrop. The strike is approximately north-south, and the dip varies according to local structural peculiarities but averages approximately $0.5 \mathrm{~m} / \mathrm{km}$. The Claremont Manor is an open-marine deposit containing a variety of mollusk species that are generally confined to thin beds within the member. The poorly sorted, coarse, basal sand of the Claremont Manor differs from the underlying finegrained, well-sorted shelly sand of the St. Marys Formation. 


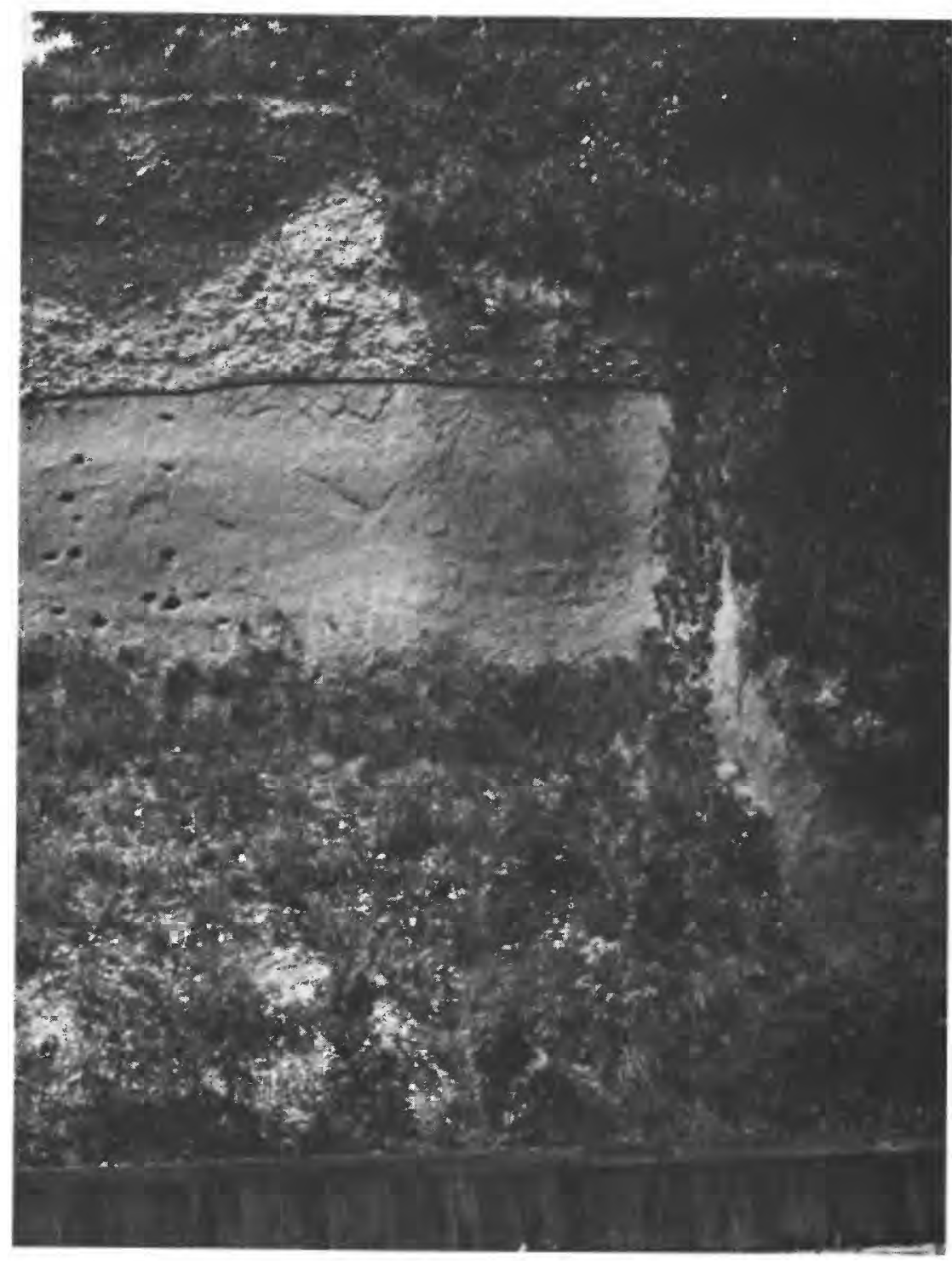

Figure 6.-Type locality of the Claremont Manor Member, Eastover Formation, and of the Sunken Meadow Member, Yorktown Formation.

Where it overlies the Choptank, the same differences are evident. The Claremont Manor differs sharply from the diatomaceous silty clay of the Calvert and from the glauconitic sands of the upper Oligocene (unnamed), the lower and middle Eocene (Nanjemoy), and Paleocene (Aquia). The Cobham Bay 
Member, which overlies the Claremont Manor, differs from the latter in being well-sorted, less silty or clayey, and in having an abundance of well-preserved mollusks in thick beds.

Locality 42. Measured section at the type locality of the Claremont Manor Member of the Eastover Formation and type locality of the Sunken Meadow Member of the Yorktown Formation. $1.3 \mathrm{~km}$ below mouth of Sunken Meadow Creek, right bank of the James River, Surry Co., Va., Claremont 7 1/2 min quad.

\section{Pleistocene(?)}

$$
\frac{\text { Thickness }}{(\mathrm{m})}
$$

Red and orange sand and gravel .......... 4.5 Yorktown Formation (in part):

Rushmere Member:

Tan fine sandy oyster and barnacle shell hash .................. 1.5

Tan fine shelly sand; Chesapecten madisonius

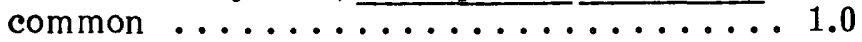

Sunken Meadow Member:

Tan shelly sand ranging from poorly sorted to sorted in different layers; phosphatic, glauconitic; sand dollar spines, ostracodes, and foraminifers abundant, Chesapecten

Eastover Formation: jeffersonius abundant ............ 2.5

Cobham Bay Member:

Isognomon abundant, sand dollar spine common, sand-size phosphate present $\ldots \ldots \ldots \ldots \ldots .0 .5$

Claremont Manor Member

Weathered tan clayey fine sand, sparsely

fossiliferous, shells decayed and soft .................... 1.5 Clayey sand, sparsely fossiliferous; sand fraction somewhat poorly sorted . . . . . . 3.0 Green-gray sandy clay containing scattered shell (decayed) and concretions (sand fraction poorly sorted to sorted in different beds); sand dollar spines abundant in certain layers . . . . . ............. 4.5

Stratigraphic relationships.- The Claremont Manor overlaps unconformably a wide range of lithologic units of varying ages. In the Petersburg (loc. 19) and Hopewell (loc. 20) areas, the Claremont Manor overlies the Nanjemoy (lower and 
middle Eocene). At the end of Chesterfield Avenue in Colonial Heights (loc. 14), it rests on coarse, cross-bedded Cretaceous sand. At Richmond, the Claremont Manor is exposed behind the city jail (loc. 8), where it overlies the diatomaceous clay of the Calvert Formation. To the east of Richmond, at Bottom's Bridge (loc. 6), in an area that apparently has been intermittently postive throughout the Tertiary, the Claremont Manor overlies unnamed beds of late Oligocene (Chickasawhayan) age. To the north of Bottom's Bridge, at Elsing Green (loc. 12) on the Pamunkey River, the Claremont Manor may again be seen to overlie the Calvert Formation. Similar exposures of the contact with the Calvert Formation may be seen at Gravatts Mill east of Hanover Court House, in King William County (loc. 21) and at Rickahock on the left bank of the Mattaponi River below Walkerton, King and Queen County (loc. 11). A short distance downstream from Rickahock, the Claremont Manor overlies a thin remnant of the St. Marys Formation at Mantua Landing (loc. 23) and at White Oak Landing (loc. 22), both in King William County. In the Tappahannock area, Essex County (loc. 67), the Claremont Manor directly overlies the St. Marys, but farther upstream at Fones Cliffs (loc. 9) it rests on the Choptank Formation. This same relationship may be seen in the series of bluffs along the Potomac River from Westmoreland State Park to Currioman Bay, Westmoreland County (loc. 24). At Mt. Airy Mill Pond in Richmond County (loc. 68), the fining-upward sequence of the St. Marys is overlain unconformably by the poorly sorted basal sand of the Claremont Manor.

The lower contact of the Claremont Manor is sharp in most places, and phosphate nodules, bone, teeth, and pebbles are present at the boundary. The member generally consists of a basal conglomerate and poorly sorted clayey sand and grades upward to a clay or silty fine sand. This fining-upward trend enables easy recognition of the basal transgressive sand. In Petersburg (loc. 16), Richmond (loc. 8), Henrico County (loc. 6) and many other localities, the shelly sands of the Cobham Bay Member overlie, in sharp contrast, the clay or silty clay of the Claremont Manor. The Cobham Bay apparently overlaps the entire extent of the Claremont Manor so that in only one area, Claremont (loc. 17) does the Yorktown rest directly on the Claremont Manor. This relationship was probably caused by local uplift and transgressive beveling.

Paleogeography.- The Claremont Manor basin covered most of the Virginia Coastal Plain and overlapped slightly into Maryland (fig. 7). The basin was open to the sea in the east but was bounded by an emerged part of southeastern Maryland to the north, and by the Virginia Piedmont to the west. It is 


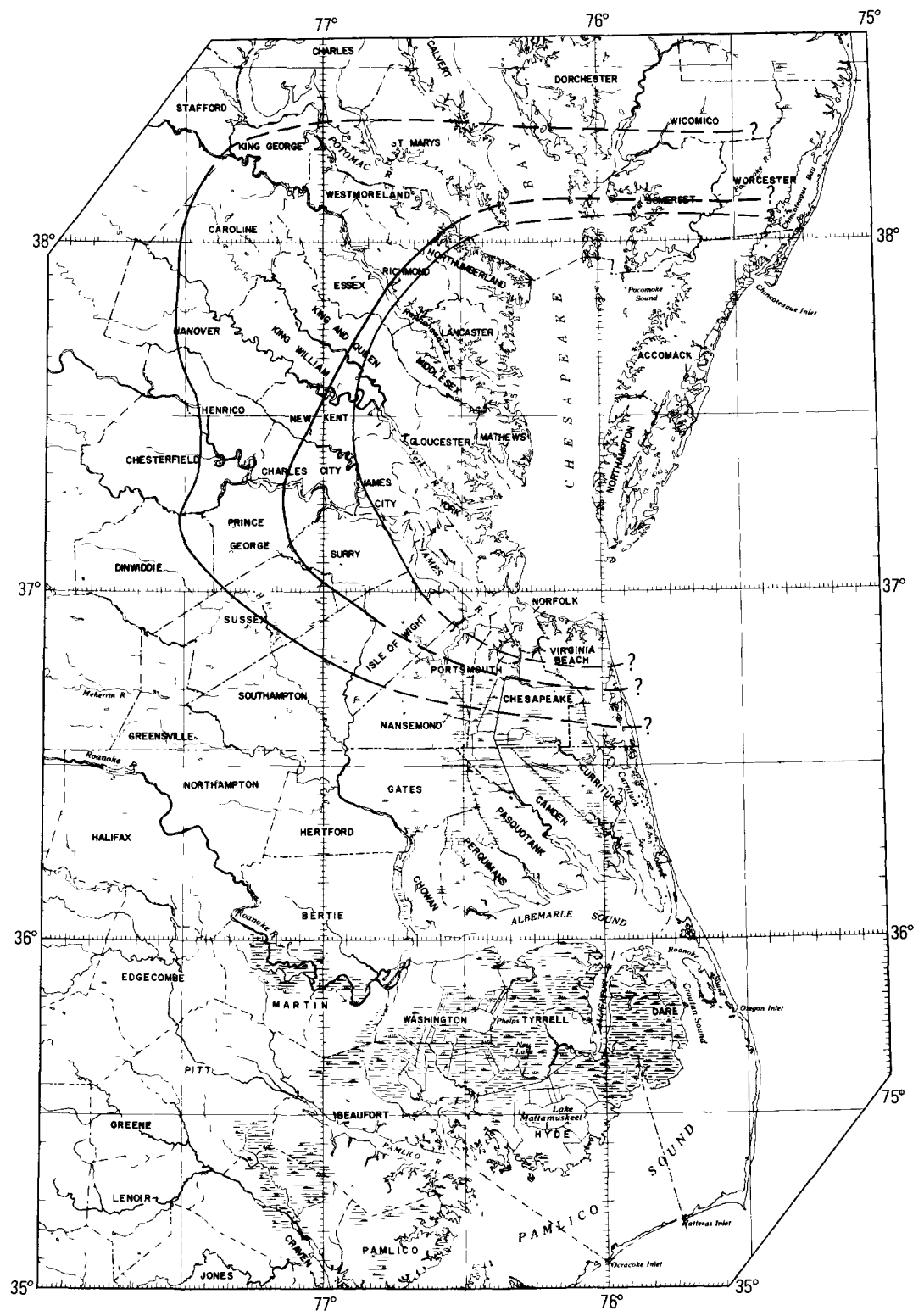

$\begin{array}{lllllll}0 & 10 & 20 & 30 & 40 & 50 & 60 \mathrm{KILOMETERS}\end{array}$

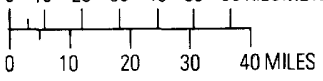

Figure 7.-Basin configuration of the Claremont Manor Member, Eastover Formation. Extent of outcrops of the Claremont Manor Member (westernmost line) and locations where the lower contact (center line) and upper contact (easternmost line) reach sea level. 
bordered on the south by a tectonically active, high area in North Carolina that had been emergent since the deposition of the Pungo River Formation (upper lower to lower middle Miocene).

South of the James River, the Claremont Manor is present in the subsurface in the vicinity of Dendron, Va., but outcrops are lacking and it has not been found as far south as the Nottoway River. A thick sequence $(9 \mathrm{~m})$ is present at Petersburg (loc. 16, 19), but just below Baileys Creek on the right bank of the James River (loc. 13) it is entirely absent on the apex of the "Hopewell High" area. Only a short distance to the east of this "High," in the Tar Bay area (loc. 20), the Claremont Manor is again well represented. The member is present at Richmond (loc. 8) and extends northward into Carolina County (loc. 26). At least $9 \mathrm{~m}$ of Claremont Manor is present at Stratford Hall (loc. 24) on the Potomac, and the unit may be present overlying the St. Marys in St. Marys County, Md. (loc. 10). On the Eastern Shore of Maryland, Claremont Manor guide fossils were found in a well at Crisfield (loc. 27) at the 40to $46-\mathrm{m}$ interval.

Age and Correlation.- The Claremont Manor is probably of early Tortonian Age, early late Miocene (Berggren and Van Couvering, 1974). The lower part of the overlying Cobham Bay member has been dated radiometrically (K/Ar) from glauconite at $8.7+0.4$ million years. Beds on the St. Marys River in Maryland that have been traditionally assigned to the middle of the underlying St. Marys Formation have yielded glauconite dated at $12.0 \pm 0.5$ million years (Krueger Enterprises Inc., Geochron Laboratories). Although various authors have indicated dissatisfaction with glauconite as a basis for radiometric dating and the dates may be too young, a Tortonian Age seems probable at present.

Paleoenvironment.- The Claremont Manor sea is believed to have been open marine, but the molluscan species diversity is substantially lower than that of the preceding St. Marys Formation or of the later Cobham Bay Member. This condition may be a function of both lower temperature and chemical conditions in the embaymnent. The large percentage of silt and clay characteristic of the Claremont Manor may also have been an inhibiting factor to molluscan proliferation. Near the center of the embayment and in its easternmost exposures, diversity increases as does the sand content. The increase in sand content toward the basin center reflects the facts that the dip is low and that parts of the eastern and central basin were relatively postive and were apparently influenced by currents. Also, the easternmost beds are younger, and water conditions apparently changed to higher current energy. As a whole, the Claremont Manor's fossil assemblages are poorly preserved and 
at many localities consist only of molds and casts. The best preserved fossils are found along the James River in Surry County from Claremont to Cobham Wharf and consist mainly of mollusks. In the Petersburg and Richmond area, large accumulations of diatoms are present in the clay, indicating that the area was a protected part of the embayment.

Molluscan Assemblage - The following mollusks are commonly found in the Claremont Manor Member:

Scapharca carolinensis (Dall, 1897)

Scapharca clisea (Dall, 1898)

Scapharca sp.

Scapharca virginiae (Dall, 1897)

Glycymer is virginiae (Dall,1897)

Isognomon sp.

Chesapecten middlesexensis (Mansfield, 1836)

Ostrea sp.

Lucinoma contracta (Say, 1824)

Crassatell a surryensis (Mansfield, 1928)

Cardium laqueatum ssp.

Euloxa la tisulcata (Conrad, 1839)

Glossus fraterna (Say, 1824)

Dosinia acetabulum (Conrad, 1832)

Lirophora dalli (OIsson, 1914)

Mercenaria sp. nov.

Pleioryt is sp. nov.

Panopea goldfussii (Wager, 1839)

Turritella sp. aff. T. plebeia Say, 1824

Ecphora sp.

\section{Cobham Bay Member}

Definition and Description.- The Cobham Bay Member is named for exposures along the James River at Cobham Bay (fig. 8, 9). The type section is $0.8 \mathrm{~km}$ below Cobham Wharf, Surry County, Va. (loc. 28). At Cobham Bay, the member reaches a thickness of $3.7 \mathrm{~m}$ and crops out from below Claremont Wharf to Lower Chippokes Creek. The Cobham Bay Member consists of a fine-grained well-sorted shelly sand throughout most of its geographic extent. Only locally, where structural or depositional features created barriers, have clays accumulated. One such location is found along the Rappahannock River from Bayport (loc. 4), Middlesex County, to Bowlers Wharf (loc. 2), Essex County. Sandy laminae increase in thickness to the east and clay laminae correspondingly thin in that direction. Near the apex of the structure at Bayport, only a trace of clay laminae remains in the fine sand. However, these features are local and the Cobham Bay retains its clean, sandy, 

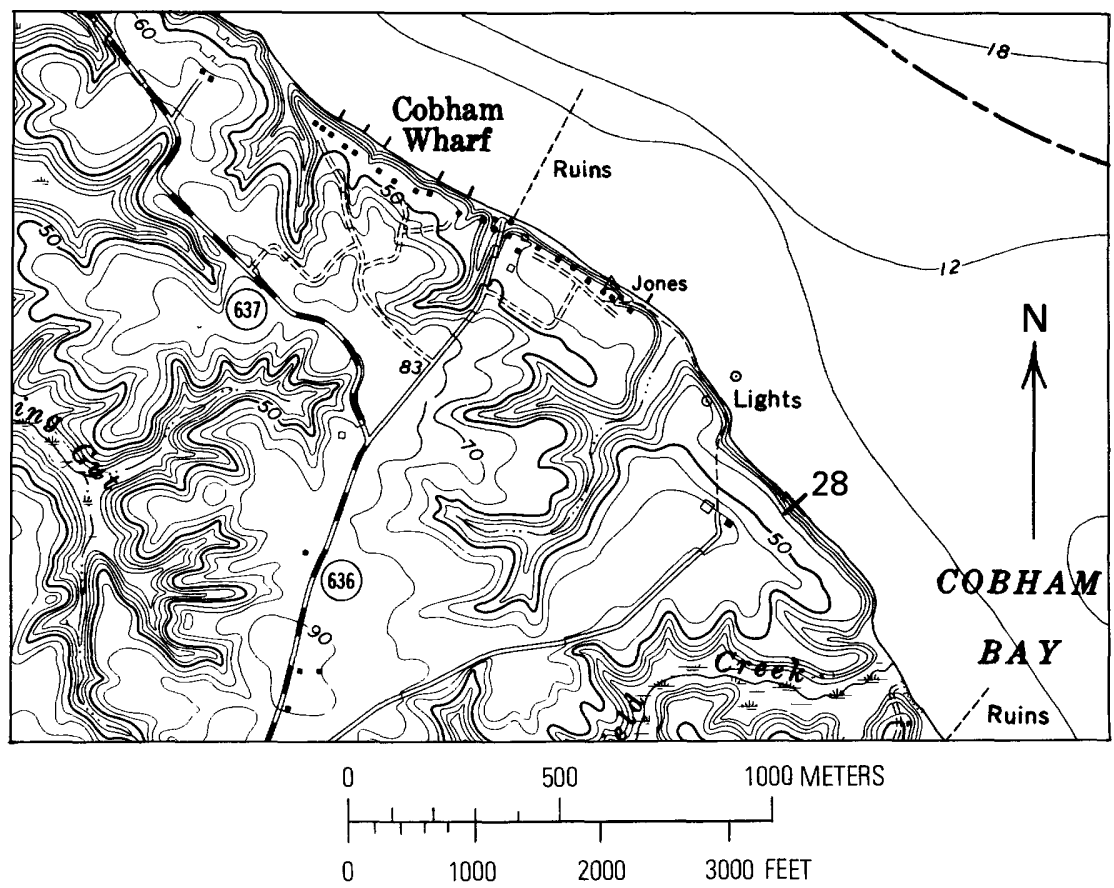

CONTOUR INTERVAL 10 FEET

NATIONAL GEODETIC VERTICAL DATUM OF 1929

DEPTH CURVES IN FEET-DATUM IS MEAN LOWER LOW WATER

SHORELINE SHOWN REPRESENTS THE APPROXIMATE LINE OF MEAN HIGH WATER

Figure 8.-Location of the type section of the Cobham Bay Member, Eastover Formation.

characteristics over most of the basin. This member contains large numbers of fossil mollusks, which are indicative of an open-marine, subtropical shallow embayment. Grayish blue (5 PB 5/2) where fresh, the Cobham Bay sediments weather to a yellowish orange (10 YR 8/6). The Cobham Bay varies in thickness from $1.0 \mathrm{~m}$ in the area of Murfreesboro, N.C. (loc. 29), to $3.6 \mathrm{~m}$ at Wilcox Lake in Petersburg (loc. 16), $3.6 \mathrm{~m}$ at Richmond (loc. 8), $12 \mathrm{~m}$ at Bayport on the Rappahannock River (loc. 4), and $3 \mathrm{~m}$ in St. Marys County, Md. (loc. 10). In the type area (loc. 28), the Cobham Bay is $3.7 \mathrm{~m}$ thick. The strike is approximately north-south, but the dip varies with local structural features.

In the previously mentioned Bowlers Wharf-Bayport area along the Rappahannock River, the Cobham Bay dips to the northwest (upriver) at a rate of $2.0 \mathrm{~m} / \mathrm{km}$. To the east of Bayport, which is the apex of the structure, the Cobham Bay resumes the normal seaward dip, but at only $0.3-0.6 \mathrm{~m} / \mathrm{km}$. 


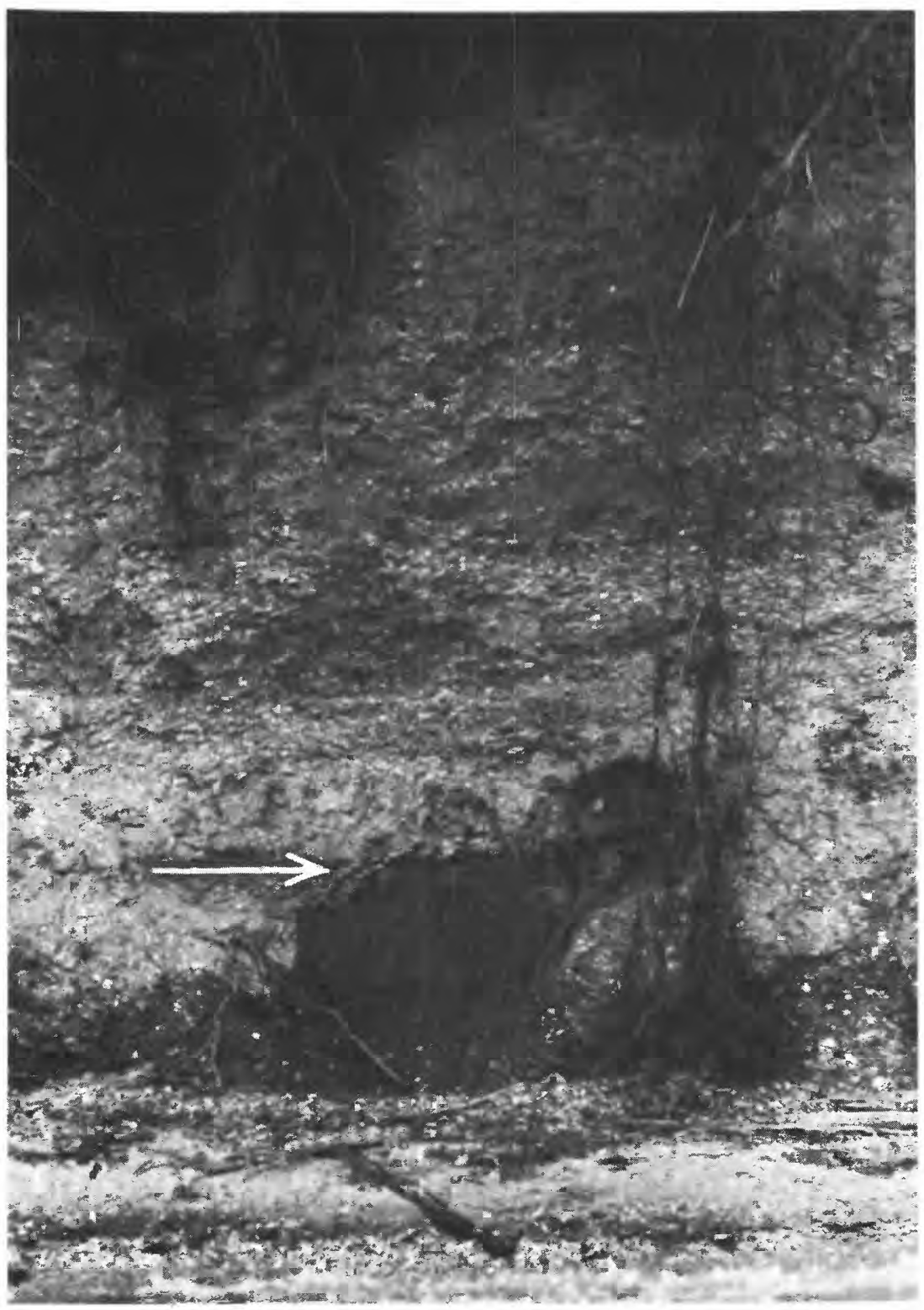

Figure 9.-Type locality of the Cobham Bay Member, Eastover Formation.

Throughout most of the basin, the normal seaward dip is maintained at a rate of approximately $1.0 \mathrm{~m} / \mathrm{km}$. The locus of deposition seems to have been in the York River area. Most of 
the Cobham Bay overlies the Claremont Manor, and its wellsorted, less clayey sand, and its sandy shell beds differ from the units of the Claremont Manor. Sediments of Cobham Bay lithology containing Cobham Bay guide fossils have been found by the authors in the vicinity of New Bern, N.C., near the mouth of the Trent River. These deposits appear to be erosional remnants but indicate an extensive basinal area in North Carolina. The Cobham Bay basin is bounded to the north by the uplifted coastal plain of southeastern Maryland that it slightly overlapped, to the west by the Virginia Piedmont, and to the south by a structural high in the Neuse River area.

Locality 28. Type section of the Cobham Bay Member of the Eastover Formation. $0.8 \mathrm{~km}$ below Cobham Wharf, right bank of the James River, Surry 7 1/2 min quad.

Obscured by vegetation $\ldots \ldots \ldots \ldots \ldots \ldots \ldots . . \ldots$

Yorktown Formation (in part):

Rushmere Member:

Tan fine shelly sand, clayey, phosphatic, partially indurated, partially leached; fine broken shell present: Chesapecten madisonius and Chama sp. common ............. 1.5

Sunken Meadow Member:

Tan fine shelly sand, phosphatic; Glycymeris abundant, Ostrea, Turritella, sand dollar spines ...................... 0.8 Tan fine shelly sand, glauconitic, phosphatic; Placopecten clintonius and Chesapecten jeffersonius abundant, sand dollar spines common; cetacean bone commonly found along base of

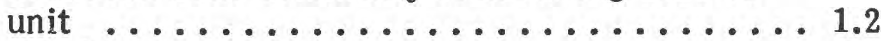

Eastover Formation

Cobham Bay Member:

Tan fine shelly sand, glauconitic, phosphatic slightly silty (sand fraction sorted); Argopecten and Chesapecten middlesexensis abundant .................... 1.1 Tan fine slightly silty, sorted sand; fewer shells than in above unit $\ldots \ldots \ldots \ldots .0 .5$ Yellow-tan medium-fine clean shelly sand, quartz somewhat poorly sorted; some phosphatic grains of organic origin; larger quartz grains rounded; many Chesapecten and Crassatella $\ldots \ldots \ldots \ldots \ldots \ldots . . \ldots . . . \ldots$ Tan fine sand containing abundant broken fine 
shell; many bivalves are articulated; Glycymeris, Mercenaria, Anadara, Chione, and Crassatella abundant ....................... 0.6

Tan fine shelly, slightly clayey, medium-fine sand, sorted, glauconite, phosphatic; containing very abundant broken fine shell $\ldots \ldots \ldots \ldots .0 .3$ Tan fairly well-sorted fine quartz sand; containing large shells (some bivalves articulated), Chesapecten, Isognomon ........... 0.4 - undulating contact

Claremont Manor Member:

Blue-gray sandy clay; fraction is fine, moderately sorted to poorly sorted in different horizons; sand dollar spines common; scattered poorly preserved shell; top of unit burrowed from above .................. 1.8 -approximate mean low-tide level

Stratigraphic relationships.-At Murfreesboro, N.C. (loc. 15), and along the Noitoway River near Littleton, Sussex County, Va. (loc. 30), the Cobham Bay Member overlies the light-gray sand and clay of the Cretaceous. However, over most of its geographic range, the Cobham Bay unconformably overlies the Claremont Manor Member. At Petersburg (loc. 16) and at Richmond (loc. 8), the fine, well-sorted, shelly sands of the Cobham Bay overlie diatomaceous. clays of the Claremont Manor. In the Claremont area, below the mouth of Sunken Meadow Creek (loc. 7), a thin tongue of the Cobham Bay overlies the poorly sorted silty sand of the Claremont Manor. Above the mouth of Sunken Meadow Creek (loc. 17), the Cobham Bay Member has been entirely removed by transgressive beveling of the younger Yorktown sea. Downriver from Sunken Meadow Creek, the Coham Bay thickens to its maximum thickness of $4.6 \mathrm{~m}$ in the Cobham Wharf area. The contact between the Claremont Manor and the Cobham Bay along this stretch undulates and in some areas has a relief of 0.6 to 0.9 $\mathrm{m}$. Shell bands in the underlying Claremont Manor were excavated in places (loc. 1) by scouring of the transgressing Cobham Bay sea. The Cobham Bay dips below sea level along the James River at Grove Wharf, James City County (loc. 31), where it is overlain by the Sunken Meadow Member of the Yorktown Formation. Just below Hopewell, Prince George County (loc. 13), a thin $(0.3 \mathrm{~m})$ bed of Cobham Bay directly overlies the lower and middle Eocene Nanjemoy Formation; the Claremont Manor was completely removed by erosion. To the east and west of this area, the Cobham Bay overlies clayey beds of the Claremont Manor. At Bottom's Bridge, Henrico County 
(loc. 6), a structurally high area, a thin $(0.3 \mathrm{~m})$ bed of Cobham Bay overlies the silty clay of the Claremont Manor. This same stratigraphic relationship is also present to the north, exposed in deep ravines near Tunstall, New Kent County (loc. 32). Along the Pamunkey River, the Cobham Bay is first exposed where it descends to river level just west of Romancoke on the left bank of the Mattaponi at Court House Landing, King and Queen County (loc. 36), the Cobham Bay consists of $2.4 \mathrm{~m}$ of fine, wellsorted, slightly clayey, shelly sand. This contrasts with the poorly sorted very clayey medium to fine sand of the Claremont Manor found upstream at White Oak Landing (loc. 22). Along the Rappahannock River, the Cobham Bay is exposed from Fones Cliffs (loc. 9) in Richmond County discontinuously to Whiting Creek, Middlesex County (loc. 37). At Fones Cliffs, it is seen overlying the Claremont Manor, but its lower contact is obscured. In the Rte. 621 road cut just south of Connellee Mill Pond (loc. 69), the glauconitic basal sand of the Cobham Bay overlies the burrowed clay of the Claremont Manor at an elevation of $23 \mathrm{~m}$. The Cobham Bay lower contact is at $13 \mathrm{~m}$ ASL (above sea level) at Bayport, Middlesex County (loc. 4), but is only $0.9 \mathrm{~m}$ ASL or less $10 \mathrm{~km}$ away at Bowlers Wharf, Essex County (loc. 2). This dip is probably structurally controlled and is too great to reflect a primary depositional dip. Around Urbanna (loc. 5), the Cobham Bay is extensively exposed as it also is at Burhans Wharf (loc. 38) and Whiting Creek (loc. 37) in Middlesex County. The outcrop at Burhans Wharf exhibits a sharp westward dip and may represent the sloping flanks of a local bar. Horizontal strata just upstream at Urbanna (loc. 5) and just downstream at the mouth of Whiting Creek (loc. 37) indicate that the westward dipping of beds is a local feature and probably not related to local structural activity, but rather due to depositional conditions. In contrast to the normally fine sand of the Cobham Bay Member, the exposure of that member on the right bank of the Piankatank at Freeport (loc. 39) and Blands Wharf (loc. 40) contain coarse sand and pebbles. This is interpreted to indicate an influx of coarse deltaic detritus. Similar deposits were made on Maryland's eastern shore during the late regressive stages of the Cobham Bay sea. Auger holes on Virginia's eastern shore (J. Owens, C. Denny, R. Mixon, unpub. data, 1977) in the Cobham Bay sequence penetrated coarse sand and pebbles. Along the Potomac, the Cobham Bay may be seen in a few places along Westmoreland Bluffs (loc. 24), and along Hull Creek in Northumberland County (loc. 41). In St. Marys County, Md. (loc. 10), the Cobham Bay overlies the Claremont Manor Member.

The Yorktown Formation overlies most of the Cobham Bay Member. At Murfreesboro, N.C. (loc. 29), the Sunken 
Meadow Member of the Yorktown overlies the Cobham Bay, as it does along the Nottoway near Littleton (loc. 30). A similar stratigraphic arrangement exists along the James River, Va., from Grove Wharf, James City County (loc. 31), to Sunken Meadows Creek in Surry County (loc. 42). At Baileys Creek near Hopewell (loc. 13) and along Lieutenant Run at Petersburg (loc. 43), the Rushmere Member of the Yorktown Formation directly overlies the Cobham Bay. In the Richmond area, the Yorktown is not present, and the Cobham Bay is capped by a weathered residuum and coarse sand and gravel. Farther to the east, at Bottom's Bridge (loc. 6), the Sunken Meadow Member overlies the Cobham Bay as it does throughout most of King William County. At Fleets Mill in King William County (loc. 44), a very thin $(15 \mathrm{~cm})$ bed of the Sunken Meadow Member overlies the Cobham bay. Undifferentiated Yorktown may be seen to overlie a back-barrier sequence of laminated clays of the regressive Cobham Bay in a road cut along State Rte. 360 at Piscataway Creek, Essex County (loc. 45). The Cobham Bay-Sunken Meadow contact may be interpreted to be at sea level just below the mouth of Felgates Creek on the York River, York County (loc. 46), on the basis of an unpublished manuscript (1890) by G. D. Harr is, but the cliff line has been largely obscured by riprap and covered by vegetation.

Paleogeography.-The Cobham Bay sea covered most of the Virginia Coastal Plain and overlapped slightly into southeastern Maryland (fig. 10). To the west, the Cobham Bay slightly overlapped the Piedmont in the northern part of the State, but south of Petersburg the shoreline trended southeast. Only very thin beds of the Cobham Bay are known as far south as the Nottoway and Meherrin Rivers. The northeastern part of the North Carolina Coastal Plain was apparently positive at this time, but remnants of Cobham Bay-age sediments in the Neuse River-New Bern area (loc. 47 and 48) indicate that a small embayment existed here at this time. A deep open-pit phosphate mine at Aurora, Beaufort County, N.C. (loc. 49), exposes no Eastover Formation sediments, and the Yorktown Formation rests directly on the Pungo River Formation (lower and middle Miocene).

Age and Correlation.- The Cobham Bay Member is of late Tortonian Age (middle late Miocene). As previously mentioned, a radiometric date on glauconite from the lower part of the Cobham Bay Member is $8.7+0.4$ million years, and beds judged to belong to this member from the shallow subsurface of the eastern shore of Virginia have been dated, by means of glauconite, at $6.46 \pm 0.15$ million years (J. P. Owens, 1977, written commun.). Chesapecten middlesexensis, one of the characteristic species of the Cobham Bay Member, occurs in the 


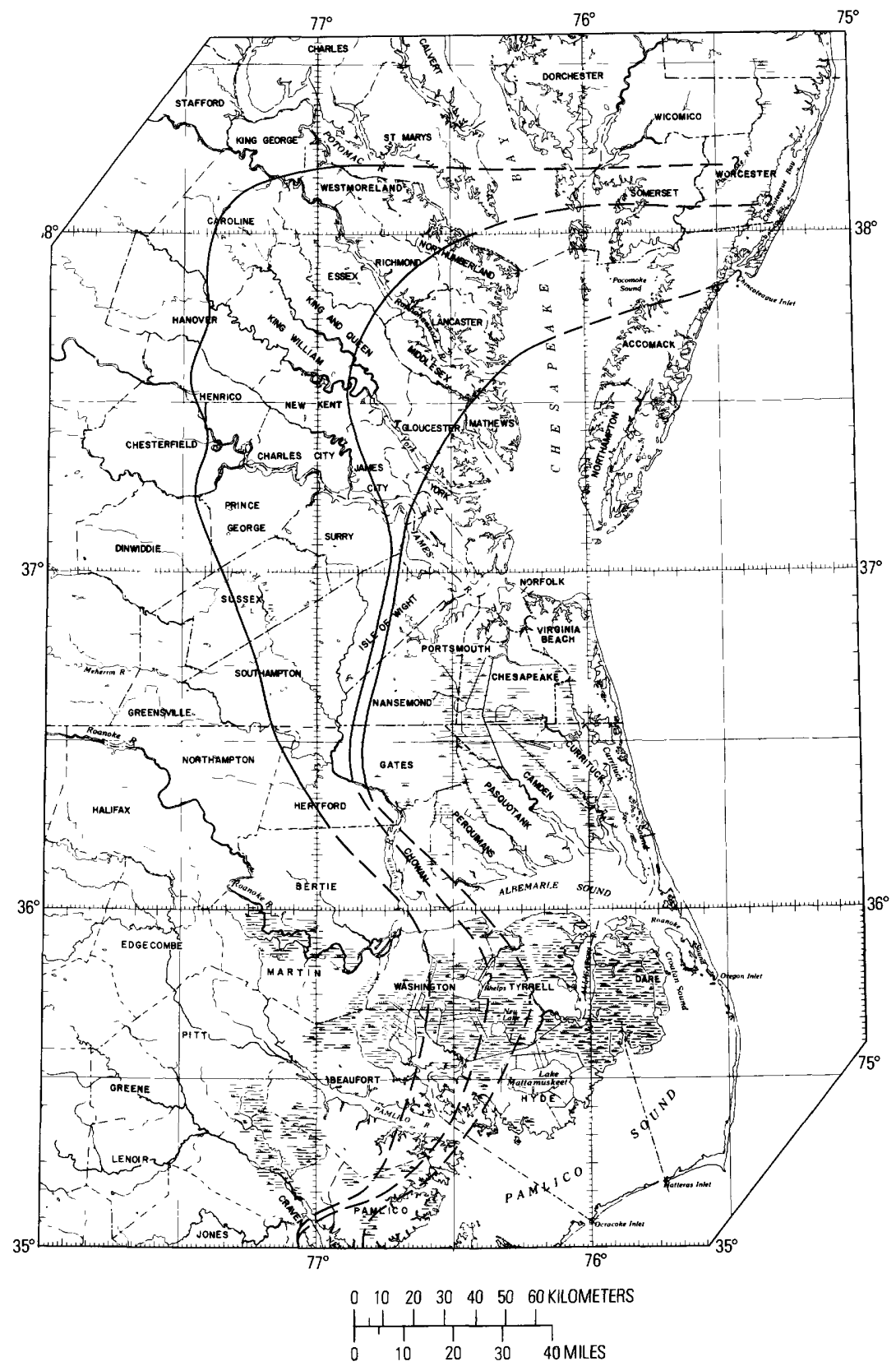

Figure 10.-Basin configuration of the Cobham Bay Member, Eastover Formation. Extent of outcrops of the Cobham Bay Member (westernmost line) and locations where the lower contact (center line) and upper contact (easternmost line) reach sea level. 
Arca zone of the Miocene of Florida. Akers (1972) placed beds of the Arca zone in planktonic foraminifer zone N17, which is largely of late Tortonian Age (Berggren and van Couvering, 1974). The ostracode Aurila redbayensis (Howe and Brown, 1935) is present in the upper part of the Cobham Bay in the shallow subsurface of the eastern shore of Virginia and in the Arca zone (J. E. Hazel, written commun., 1975). These data support the age interpreted from glauconite radiometry.

Paleoenvironment.- The Cobham Bay sediments were deposited in a fairly shallow open-marine embayment. The abundant and varied molluscan assemblage indicates favorable substrates, abundant food supply, and warm-temperate to subtropical conditions. Two main mollusean biofacies are present throughout the basin. One consists of large numbers of the small bivalve, Spisula rappahannockensis Gardner. This species thrived in northern and northwestern sections of the basin and apparently preferred quiet, slightly more silty substrates, although they are present in low numbers throughout the basin. The other biofacies were dominated by large species of Chesapecten, Mercenaria, and Isognomon. These taxa apparently preferred higher energy conditions and clean sandy substrates. The exposure below Bowlers Wharf (loc. 2) typifies the Spisula biofacies, and the exposure at Cobham Wharf (loc. 28) typifies the Chesapecten-Mercenaria-Isognomon biofacies.

Molluscan Assemblage.-The following mollusks are commonly found in the Cobham Bay Member:

Scapharca carolinensis (Dall, 1897)

Scapharca arata (Say, 1824)

Striarca centenaria (Say, 1824)

Glycymer is sp.

Isognomon sp.

Euvola smithi (Olsson, 1914)

Chesapecten middlesexensis (Mansfield, 1936)

Carolinapecten urbannaensis (Mansfield, 1928)

Placopecten princepoides (Emmons, 1858)

Pododesmus philippi Gardner, 1943

Ostrea sp.

Ostrea compressirostra Say, 1824

Stewartia anodonta (Say, 1824)

Pseudochama corticosa (Conrad, 1833)

Astarte rappahannockensis Gardner, 1943

Astarte sp.

Crassatella urbannaensis (Mansfield, 1928)

Cardium laqueatum (Conrad, 1831)

Spisula delumbis (Conrad, 1832)

Spisula bowlerensis (Gardner,1943)

Spisula rappahannockensis (Gardner, 1943) 
Euloxa latisulcata (Conrad, 1839)

Glossus fraterna (Say, 1824)

Macrocallista sp.

Dosinia acetabulum (Conrad, 1832)

Lirophora sp.

Mercenaria sp.

Pleioryt is sp.

Panopea goldfussii Wagner, 1839

Kuphus fistula (H. C. Lea, 1843)

Turritella plebeia Say, 1824

Tripsycha virginica (Conrad, 1838)

Pterorhytis umbrifer (Conrad, 1832)

Ecphora sp.

Bulliopis quadrata (Conrad, 1830)

Busycotypus sp.

Busycotypus coronatum (Conrad, 1840)

Oliva idonea Conrad

Conus sp.

\section{PLIOCENE SERIES}

\section{YORKTOWN FORMATION}

\section{Previous Work}

The first comprehensive treatment of the strata on the York River in the vicinity of Yorktown, Va., was done by Harris (1890, unpub. manuscript). Dall and Harris (1892) described some of the beds in this area but made no attempt to name them. In 1906, Clark and Miller described these beds and beds on the James River as the Yorktown Formation but gave no type section. In 1912, Clark and Miller greatly expanded this description and gave many sections. No type section was established, but a composite section, originally made by Harris, was given. Although Clark and Miller described the Yorktown Formation, they had difficulty recognizing the unit in areas remote from the York River-James River sections. Beds now known to belong to the Yorktown at Petersburg, Va. (loc. 43), were considered to be Calvert, and the same beds along the Nottoway River (loc. 50) were placed in the St. Marys Formation. Mansfield (1927, unpub. thesis) established a stratigraphic scheme for the beds in question and, in 1928, published an abbreviated form of his correlation chart. Mansfield excluded the "Perna beds" from the Yorktown and considered the Pecten clintonius beds as the lowermost unit of the Yorktown. Thus, the beds were distinguished primarily on paleontologic grounds. Mansfield (1931, 1943) expanded his 
description of the Miocene units but gave no type section for the Yorktown and divided the formation only into faunal zones. His work lacked lithostratigraphic treatment of the beds, and no type section for the Yorktown. John (1969) recognized the presence of several lithofacies within the Yorktown, but followed Mansfield's zonation closely.

Gibson (1971, p. 12) placed beds in the Yorktown Formation that had been considered to be St. Marys by Johnson and by other workers. These beds are properly assigned to the Eastover Formation. Teifke (1973) assigned all the beds above the Calvert Formation to the Yorktown and included beds placed in the Choptank and St. Marys, as well as those herein assigned to the Eastover Formation.

\section{Redefinition and Description}

The Yorktown Formation consists of a basal, pebbly, coarse-grained sand unit, a shelly fine-grained sand unit, a very fine grained sandy clay unit, and an upper sandy shell hash. These various units are herein described as four members. In ascending order from the base, they are the Sunken Meadow Member, the Rushmere Member, the Morgarts Beach Member, and the Moore House Member. A lectostratotype for the Yorktown Formation is herein designated. The original description of the Yorktown Formation (Clark and Miller, 1906) did not clearly designate a type locality but included beds at Yorktown, Va., and on the James River. The beds at Yorktown are now largely inaccessible because the cliffs have been obscured by riprap. A section near Rushmere, Isle of Wight County (loc. 61), is here designated as lectostratotype (fig. 14, 15).

\section{Stratigraphic Relationships}

The Yorktown Formation overlies the Cobham Bay Member of the Eastover Formation throughout most of the Virginia coastal plain (fig. 11). In northeastern North Carolina, the Yorktown overlies Upper Cretaceous deposits. Near Skippers, Greensville County, Va. (loc. 51), and at Halifax, Halifax County, N.C. (loc. 52), the Yorktown overlaps crystalline rocks of the Piedmont. In the structurally high area near Claremont, Va. (loc. 17), erosion by the Yorktown sea removed sediments of the Cobham Bay Member so completely that the Yorktown directly overlies the Claremont Manor Member. In the western third of the Yorktown basin, the lower contact of the formation is marked by a basal lag deposit of coarse-grained sand, pebbles, cobbles, phosphate nodules, bone, 


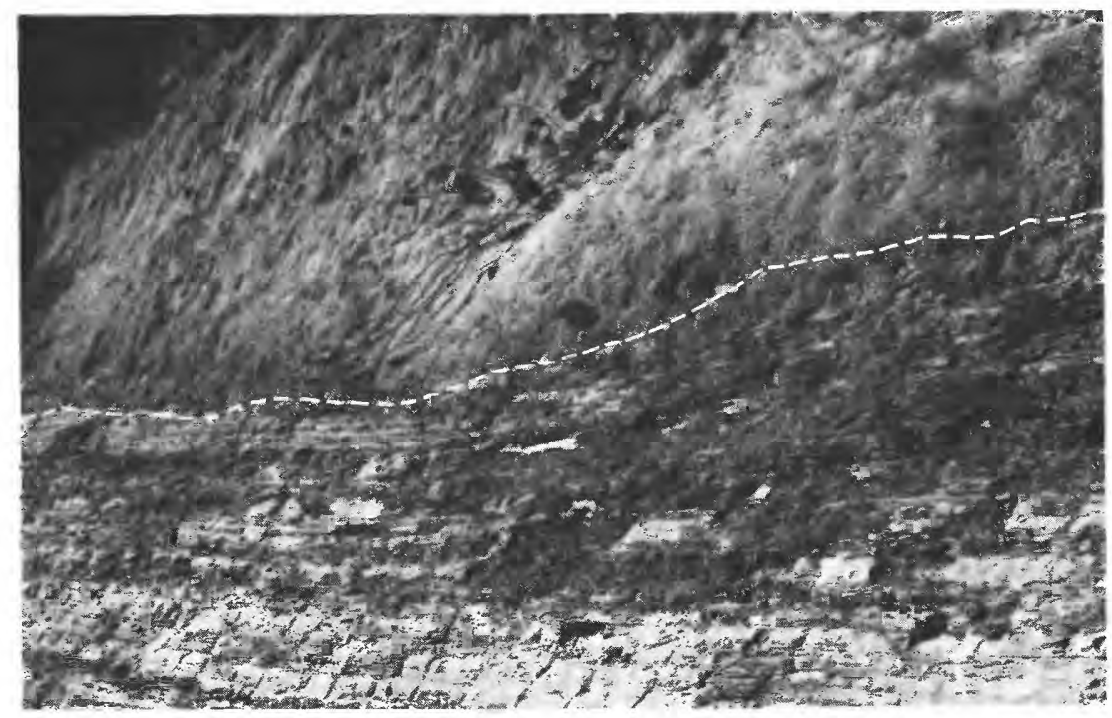

Figure 11.-Yorktown Formation overlying laminated clays of the Eastover Formation at locality 45 near Tappahannock, Va. Pebbles are visible along the contact.

and fish teeth. Toward the center part of the basin and principally in the area where the Yorktown directly overlies the Cobham Bay, the lower contact relationships are more subtle. In areas where both formations consist mostly of macromollusks in a matrix of sand, a study of the bedding features and lithology is required to separate the two units. These areas are chiefly in the vicinity of the James and York Rivers where the contact between the two formations is irregular and marked by small pebbles and bone. Over most of its extent in Virginia, the Yorktown is overlain by units of fluvial and marine-regressive coarse-grained sand and gravel. In part of northeastern North Carolina, the Yorktown is overlain by the clayey, shelly sands of the Croatan Formation. This sequence exists in the vicinity of Colerain Landing (loc. 53) and Edenhouse Landing (loc. 54) in Bertie County, N.C. and at the Texasgulf Pit, Beaufort County, N.C. (loc. 49).

The Yorktown Formation strikes approximately northeast-southwest and has a varying dip. In some areas, the Yorktown dips to the west. Reverse dipping of this type may be seen just below Morgarts Beach, Isle of Wight County, Va. (loc. 55), and just below Yorktown, York County, Va. (loc. 56). As in the Cobham Bay Member, subsurface irregularities probably caused a sharp westward dip. From the apex of the structure, 
the beds resume their normal eastward dip at a much lower angle. These relationships suggest intermittent graben-type deep-seated basement faulting during the late Miocene and early Pliocene, causing contemporaneous depositional anomalies. The average dip of the Yorktown is $0.5 \mathrm{~m} / \mathrm{km}$. The thickness of the Yorktown varies from only a few $\mathrm{cm}$ in the far westward exposures to approximately $12 \mathrm{~m}$ or more in quarries in eastern areas. In the vicinity of Yorktown, the thickness is approximately $16.8 \mathrm{~m}$.

\section{Paleogeography}

The initial transgressive phase (the Sunken Meadow Member) of the Yorktown sea covered much of the Virginia coastal plain and parts of the northeastern North Carolina coastal plain, but not until after a basinal realignment during the ensuing maximum transgression did the seas cover almost the entire North Carolina coastal plain. The Yorktown basin is bounded to the north by the emerged Maryland coastal plain and to the west by the Piedmont, which is slightly overlapped. To the south, the Yorktown is bounded by a linear high area approximating the course of the Neuse River. The early Pliocene sea overlapped this barrier, but only thin beds were deposited. South of the Neuse River high, deposits of this age have been placed in the Yorktown and Raysor Formations.

\section{Age and Correlation}

On the basis of planktonic fossils and radiometric data, J. E. Hazel (written commun., 1975, 1977) placed the Yorktown Formation entirely within the early Pliocene. Akers (1972) described zone N19 Zanclian-Age planktonic foraminifers from the Yorktown at Hampton, Va. Glauconite from the Rushmere Member near Grove Creek, James River, James City County, has been dated at $4.4 \pm 0.2$ million years (Krueger Enterprises, Inc., Geochron Laboratōries).

J. E. Hazel (written commun., 1978) stated that the basal beds of the Yorktown (the Sunken Meadow Member) are equivalent to planktonic foraminifer zone N18 in age and constitute the lower zone of the Pliocene (Berggren and van Couvering, 1974). Zone N18 began about 5.0 million years ago. If the 6.46 million-year date on the upper part of the Cobham Bay Member is correct, then the unconformity between the Cobham Bay and the Yorktown approximately represents the time equivalent of the Messinian Stage of the Mediterranean region. 


\section{Paleoenvironment}

During the initial transgressive phase of the Yorktown sea, a large open embayment existed in which large numbers of warm-temperate mollusks thrived. During the maximum transgression, the Yorktown sea reached, and even overlapped, the Piedmont, depositing the Rushmere Member clay beds with a high diversity (more than 250 species) of mollusks. These mollusks are typical of open-marine subtropical conditions. In the calmer waters after maximum transgression, clayey fine sand and silt containing the abundant small bivalve, Mulinia congesta (Conrad) were deposited. These beds are termed the Morgarts Beach Member. This member formed behind partially protective offshore bars at Chuckatuck (loc. 58), Yorktown (loc. 57), and Glebe Neck (loc. 59). Although Mulinia is somewhat euryhaline, the presence of open-marine species in the Morgarts Beach Member as far west as the Piedmont indicates normal saline conditions. Regressive sediments are seen in southeastern Virginia where the terminal Yorktown sea occupied only a final small area in Virginia. At the time of this regression, either the basin in northeastern North Carolina was emergent or later erosion and transgressive beveling removed the sedimentological record.

\section{Sunken Meadow Member}

Definition and Description.- The Sunken Meadow Member is herein named for beds in the cliffs just below Sunken Meadow Creek, on the right bank of the James River, Surry County, Va. (loc. 42) (see fig. 5).

The Sunken Meadow Member consists of a basal transgressive, coarse-to-medium, poorly sorted, very shelly sand. To the west, the lower contact of the member is marked by a coarse lag deposit. To the east the basal deposits are finer and are dominated by glauconitic and phosphatic fine shelly sand.

Stratigraphic relationships.-The Sunken Meadow unconformably overlies the Cobham Bay in much of Virginia, and to the south it overlies older stratigraphic units. Throughout its extent, the lower contact of the member is sharp. The Sunken Meadow Member is overlapped in its entire extent by the maximum transgressive phase (the Rushmere Member) of the Yorktown Formation. The Rushmere overlies the Sunken Meadow apparently conformably, although there is evidence of a brief diastem between the two members. Areas north of the Rappahannock River in Lancaster County, Va., which had been shallow marine during the deposition of the Sunken Meadow 


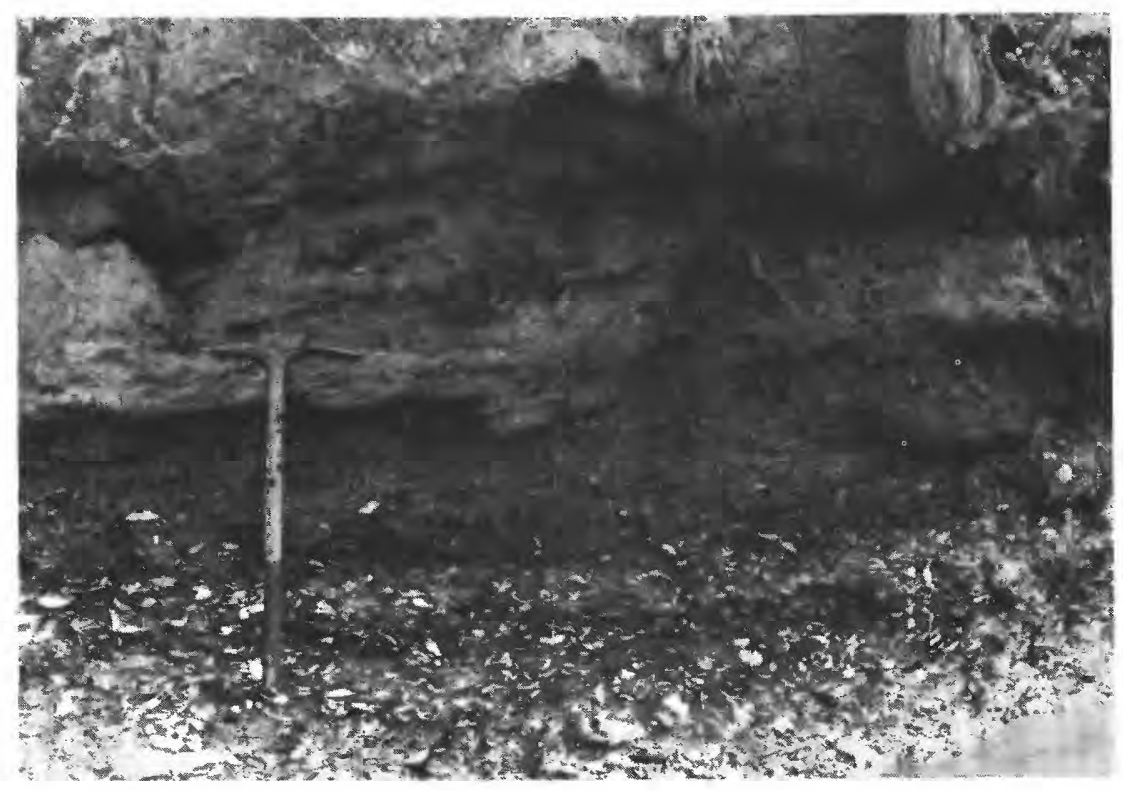

Figure 12.-Piankatank River, Va., near Martiau showing shelly beds of the Sunken Meadow Member overlain by current-bedded fine comminuted shell hash containing Ophiomorpha.

Member, became emergent during Rushmere time, and shoaling areas were present as far south as the Piankatank River (fig. 12).

At Martiau (loc. 82) and Glebe Neck (loc. 59), the Sunken Meadow Member consists of very shelly glauconitic sand and abundant large coral, indicative of a shallow open-marine environment. It is overlain by current-bedded coquinoid deposits containing Ophiomorpha, indicative of shoaling during Rushmere time. In North Carolina, the Sunken Meadow Member overlies the Cobham Bay Member of the Eastover Formation at Murfreesboro, Hertford County (loc. 29), and the Pungo River Formation at Aurora, Beaufort County (loc. 49). The Sunken Meadow strikes northeast-southwest and dips at the average rate of $0.5 \mathrm{~m} / \mathrm{km}$ but locally this dip may vary. The Sunken Meadow averages about $3 \mathrm{~m}$ in thickness, but thins to the west and pinches out near St. Stephens Church, King and Queen County, Va. (loc. 44), Manquin, King William County, Va. (loc. 60), Bottoms Bridge, New Kent County, Va. (loc. 6), below the mouth of Baileys Creek, Prince George County, Va. (loc. 13), and Homeville, Sussex County, Va. (loc. 30).

Paleogeography.- The Sunken Meadow Member occupied much of the eastern two-thirds of the Virginia coastal plain 


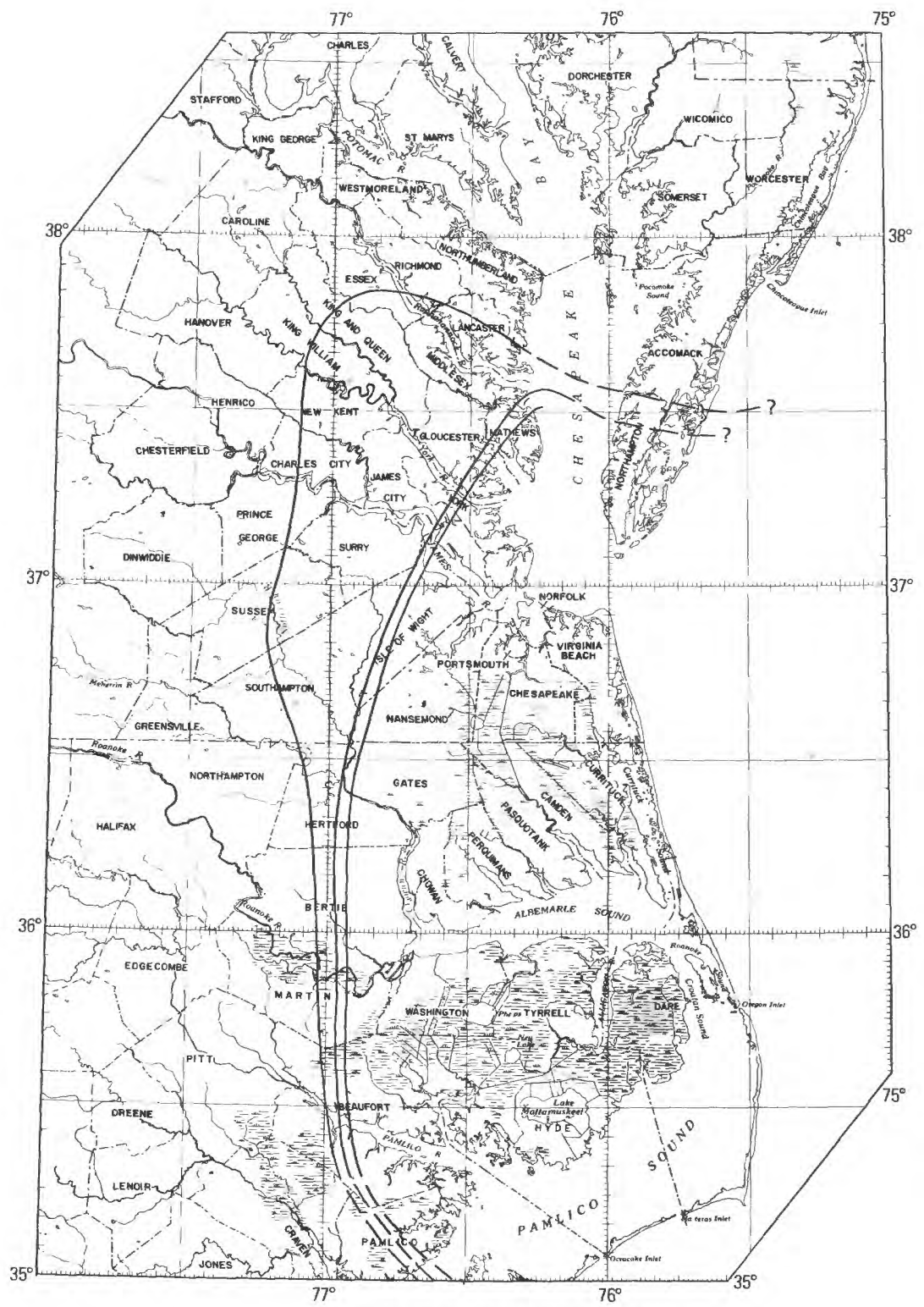

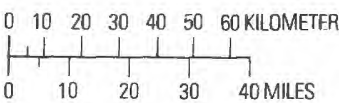

Figure 13.-Extent of outcrops of the Sunken Meadow Member of the Yorktown Formation (westernmost line) and locations where the lower contact (center line) and upper contact (easternmost line) reach sea level. 
extending as far west as King and Queen, King William, New Kent, Charles City, Prince George, Sussex and Southampton Counties in Virginia (fig. 13). In North Carolina, the Member is found in Hertford, Bertie, and Beaufort Counties.

Paleoenvironment.-Molluscan assemblages from the Sunken Meadow Member indicate that normally saline, shallowshelf conditions existed in the basin and that the sandy substrate was a favorable habitat in the mild temperate sea. Many mollusk species attained an unusually large size at this time. Diversity among the mollusks was moderately high, although somewhat less than the Cobham Bay assemblages and the later Yorktown assemblages. A structurally high area from Cape Lookout, N.C., to the Cape Fear Arch area, North and South Carolina, served as a barrier, which probably deflected warmer currents from the south. Later in the Yorktown, these barriers were breached and the accompanying moiluisean assemblages had distinctly more tropical affinities.

Molluscan Assemblages.- The following mollusks are commonly found in the Sunken Meadow Member of the Yorktown Formation:

Glycymer is subovata (Say, 1824)

Euvola smithi (Olsson, 1914)

Chesapecten jeffersonius (Say, 1824)

Pecten watsonensis (Mans field, 1936)

Pycnodonte sp.

Ostrea compressirostra Say, 1824

Stewartia anodonta Say, 1824

Lucinoma contracta (Say, 1824)

Astarte deltoidea (Gardner, 1943)

Astarte vaginulata (Dall, 1903)

Astarte coheni Conrad, 1840

Crassatella cyclopterus (Dall, 1903)

Cardium taeniopleura (Dall, 1900)

Spisula confraga (Conrad, 1833)

Glossus fraterna (Say, 1824)

Dosinia acetabulum (Conrad, 1832)

Mercenaria sp.

Mercenaria inflata (Dall, 1903)

Panopea reflexa (Say, 1824)

Kuphus fistula (H. C. Lea, 1843)

Turritella pilsbryi Gardner, 1928

Ecphora quadricostata (Say, 1824)

Oliva canaliculata (H. C. Lea, 1843)

Scaphella solitaria (Conrad, 1830)

Conus marylandicus Green, 1831

Busycon maximum (Conrad, 1839)

Lirosoma multicostata (Olsson, 1914) 

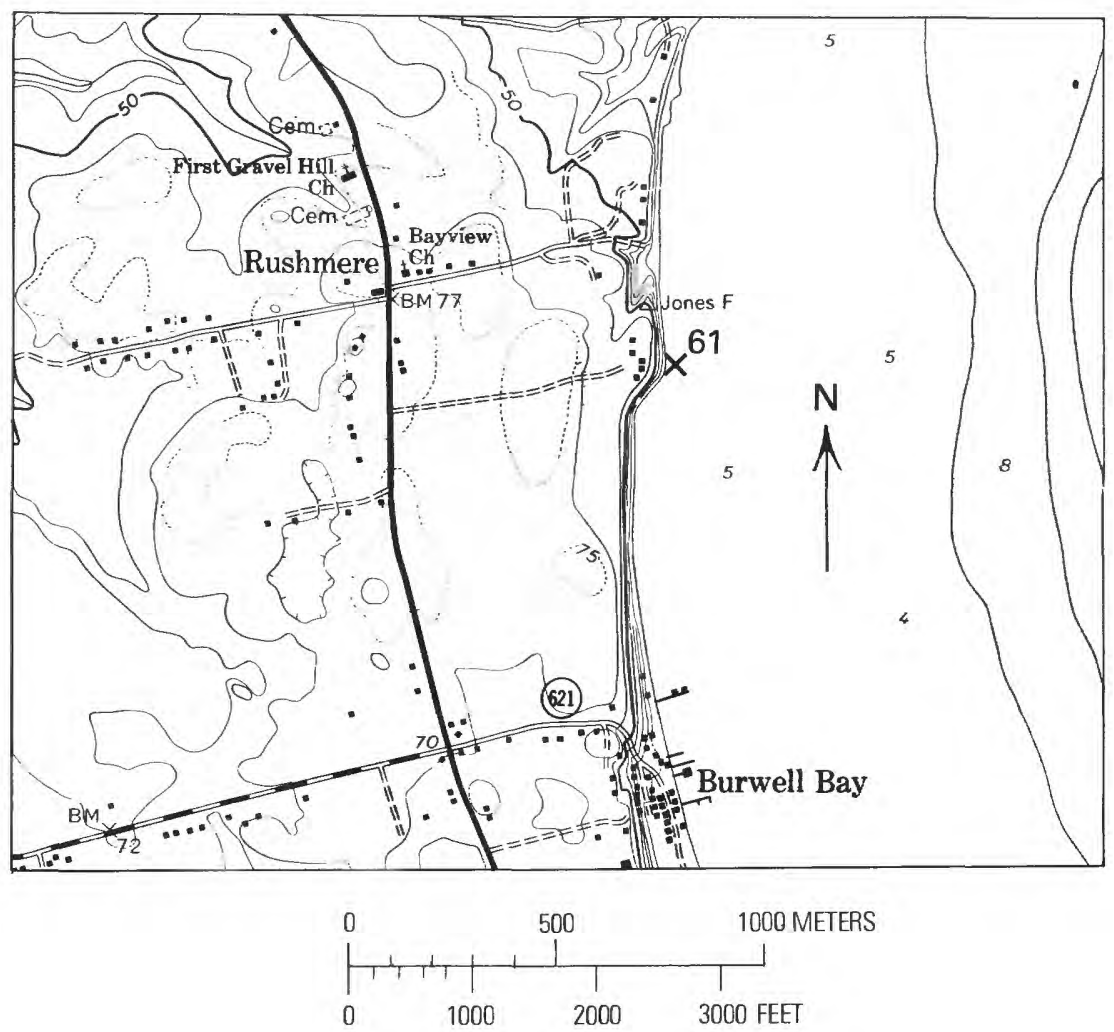

CONTOUR INTERVAL 10 FEET

NATIONAL GEODETIC VERTICAL DATUM OF 1929

DEPTH CURVES IN FEET-DATUM IS MEAN LOWER LOW WATER SHORELINE SHOWN REPRESENTS THE APPROXIMATE LINE OF MEAN HIGH WATER DASHED LINE REPRESENTS HALF-CONTOUR INTERVAL

Figure 14.-Location of Yorktown Formation lectostratotype near Rushmere, Isle of Wight County, Va. (loc. 61). Type locality of the Rushmere Member.

\section{Rushmere Member}

Definition and Description.-The Rushmere Member is herein named for beds exposed along the right bank of the James River at Burwell Bay near Rushmere, Isle of Wight County, Va. (loc. 61) (fig. 14, 15).

The Rushmere Member consists of a fine well-sorted shelly sand. Phosphatic sand and glauconite are common in amounts less than 10 percent. Some coarse sand and pebbles are present near its lower contact in areas where it overlaps the Sunken Meadow Member and rests directly on older beds (Eastover Formation or Piedmont Rocks). 


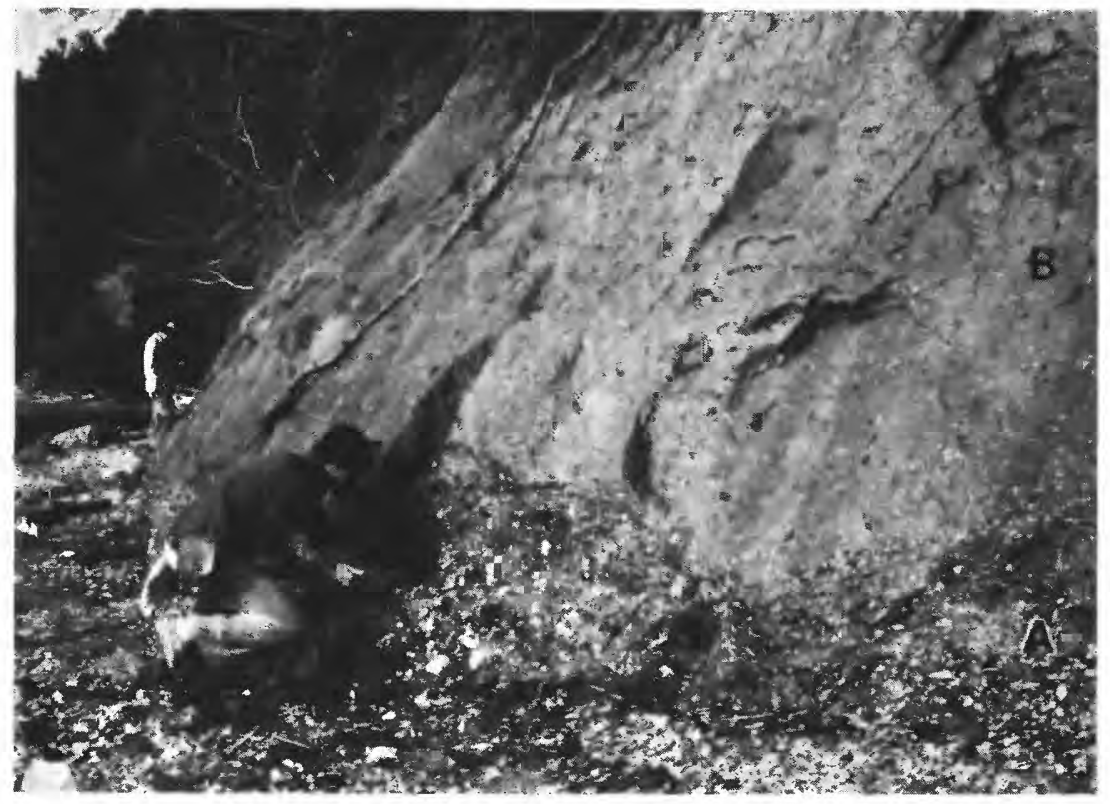

Figure 15.-Lectostratotype of the Yorktown Formation and type locality of the Rushmere Member. Shelly sand of the Rushmere Member (A) is overlain by clay of the Morgarts Beach Member (B).

Locality 61. Measured lectostratotype section of the Yorktown Formation and type locality of the Rushmere Member of the Yorktown Formation. $0.7 \mathrm{~km}$ east of Rushmere, right bank of the James River, Isle of Wight County, Va. Bacons Castle 7 1/2 min quad.

\section{$\frac{\text { Thickness }}{(\mathrm{m})}$}

Post-Yorktown:

Partially covered, probably Pleistocene . . . . . 3.0

Yorktown Formation (in part):

Moore House Member:

Reddish-brown, partially leached, indurated, coarse, broken-shell hash; Chama, Chesapecten

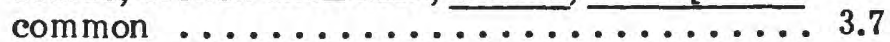

Morgarts Beach Member:

Blue-gray fine slightly sandy clay. Glauconite and phosphate present. Sand-size fraction is fine grained and highly calcareous because of large number of sand dollar spines and foraminifers. Unit appears "blocky" on face of outcrop because of 
Yorktown Formation ( in part)--Continued

Morgarts Beach Member--Continued

desiccation. Abundant mollusks include

Turritella and Mulinia ............ 5.5

Rushmere Member:

Blue-gray fine sandy clay containing abundant

shell. Sand fraction is glauconitic,

phosphatic, containing abundant sand dollar

spines and foraminifera. This unit contains

some medium-sand-size rounded

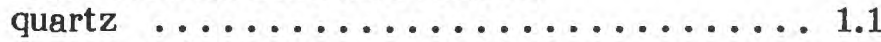

-approximate mean low-tide level-_-

Stratigraphic relationships.- The Rushmere Member overlapped the Sunken Meadow Member in its entire extent except in the area north of the Rappahannock River in Lancaster County, Va. As a result, the Rushmere rests on the Cobham Bay near St. Stephens Church, King and Queen County, Va. (loc. 44), at Manquin, King William County, Va. (loc. 60), near the mouth of Baileys Creek, Prince George County, Va. (loc. 13), and along Lieutenant Run, Petersburg, Va. (loc. 43). Near Skippers, Greensville County, Va. (loc. 51), the Rushmere rests directly on (granite) saprolite. At Halifax, Halifax County, N.C. (loc. 52), the same stratigraphic relationship exists, but near Palmyra, in Martin County, N.C. (loc. 62), the Rushmere rests on Upper Cretaceous sands. In the area around Fort Barnwell, on the Neuse River, Craven County, N.C. (loc. 63), the Rushmere-age beds overlie the bryozoan limestone of the Castle Hayne Formation. The Pliocene beds at these exposures (loc. 63) are of the same lithology and age as the Rushmere. Beds also assigned to the Yorktown are present in the Martin Marietta Quarry, in New Bern, Craven County, N.C. (loc. 64). Here the Yorktown overlies Oligocene limestone, but where solution and erosion has removed the Oligocene, Yorktown beds directly overlie the upper calcareous sandstone of the Castle Hayne. Where the Rushmere directly overlies the Sunken Meadow Member, the two are apparently conformable. A distinct contact, however, separates them in most areas. The Rushmere is overlain throughout most of its areal extent by the clayey beds of the Morgarts Beach Member. The two beds are conformable, and, though in some areas they grade into each other, they are usually separable. Areas where the Morgarts Beach Member overlies the Rushmere are discussed in the Morgarts Beach section. The Rushmere strikes approximately northeast-southwest in Virginia and approximately north-south in North Carolina. It dips at $0.5 \mathrm{~m} / \mathrm{km}$ and is as much as $4.8 \mathrm{~m}$ thick in outcrop.

Paleogeography.- The Rushmere Member represents the maximum transgressive phase of the Yorktown Formation and 


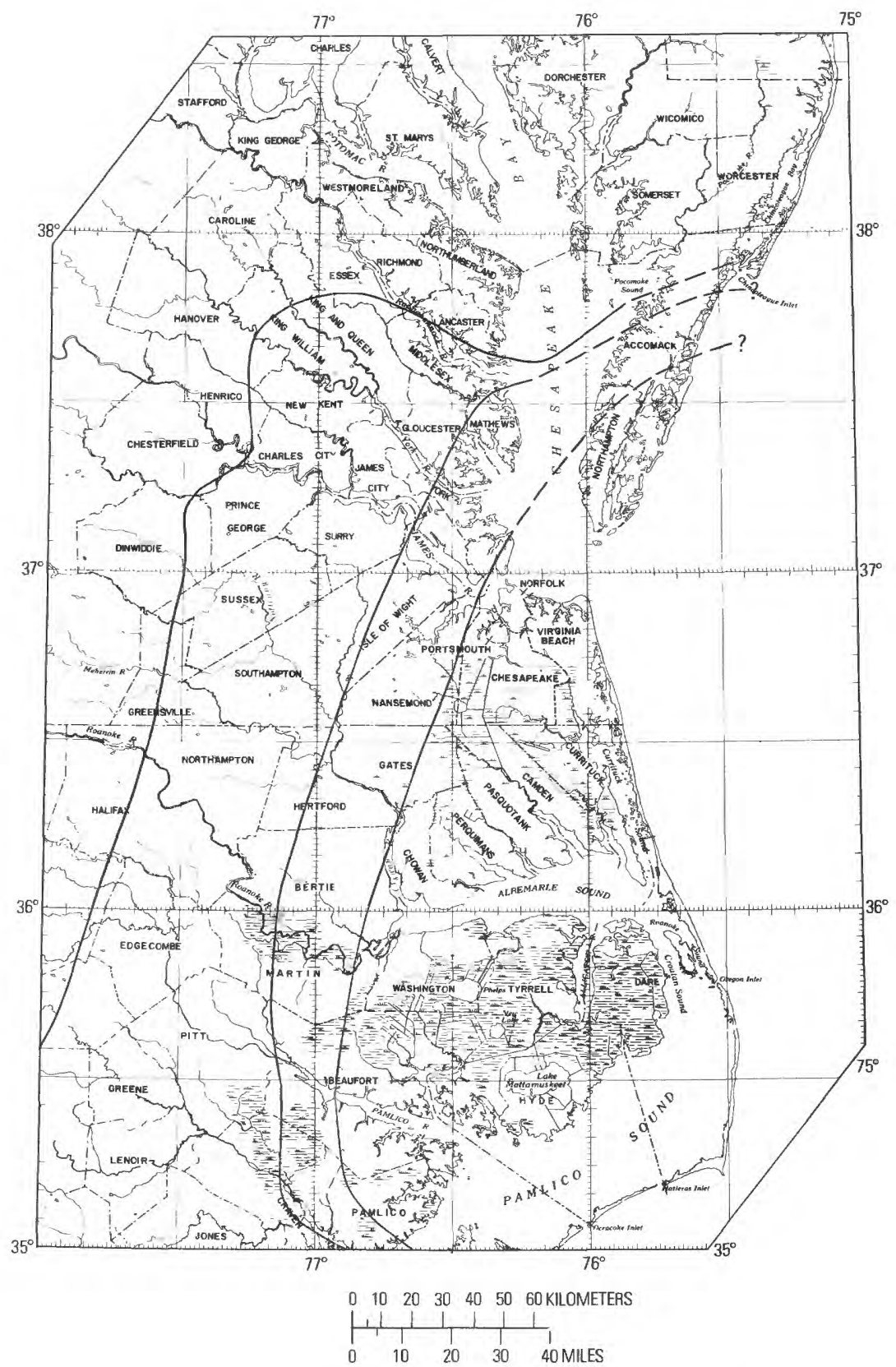

Figure 16.--Extent of outcrops of the Rushmere and Morgarts Beach Members of the Yorktown Formation (westernmost line) and locations where the lower contact of the Rushmere (center line) and upper contact of the Morgarts Beach (easternmost line) reach sea level. 
occupies the lower three-fourths of the Virginia coastal plain (fig. 16). In North Carolina, the Rushmere basin covered that part of the Coastal Plain north and northeast of the Neuse River. The western boundary of the basin was slightly west of the Fall Line. To the north, the emerged Maryland and northern Virginia coastal plains provided a boundary. To the south, the partial barrier in the Neuse River area created a separate, though interconnected, basin that contained identical sediments but a more tropical molluscan assemblage.

Paleoenvironment.- The Rushmere sea was clearly an open-marine, shallow-shelf environment that was conducive both to increased diversity and to large populations. The molluscan assemblages show a subtropical to tropical influence, especially in the eastern parts of the Yorktown basin. In the more shoreward areas, diversity decreases and many of the exotic tropical taxa are not present. South of the Neuse River barrier, the assemblage is predominantly tropical but retains many of the taxa of the northern Yorktown populations. Shallow, shoaling, offshore bar systems were present in the eastern areas in Nansemond, York, and Middlesex counties, Va. In the Aurora area, Beaufort County, N.C. (loc. 49), which was a moderately deep part of the basin, only the Rushmere Member is present but the Morgarts Beach Member occurs to the west in more shallow, quieter areas.

Molluscan assemblages.- Because of the similarity of the assemblages of the Rushmere, Morgarts Beach, and Moore House Members, mollusks of those units are considered together (See "Moore House section").

\section{Morgarts Beach Member}

Definition and Description.-The Morgarts Beach Member is herein named for beds exposed at Morgarts Beach, right bank of the James River, Isle of Wight County, Va. (fig. 17, 18).

The Morgarts Beach Member is commonly a very fine sandy to silty clay that contains a few silty, very fine sand beds. The member contains an abundant molluscan assemblage, but less abundant than that in the sandy Rushmere Member. The emergence of the offshore bars created a quiet lagoonal area to the west in which the fine sands, silts, and clays were deposited. Tilted bedding reflects the presence of these bars and, in the channels between them, the sand content is greater owing to higher energy conditions.

Locality 55. Measured type section of the Morgarts Beach Member. $1.0 \mathrm{~km}$ below Morgarts Beach, right bank of the James River, Isle of Wight County, Va. (Mulberry Island 7 1/2 min quad.). 

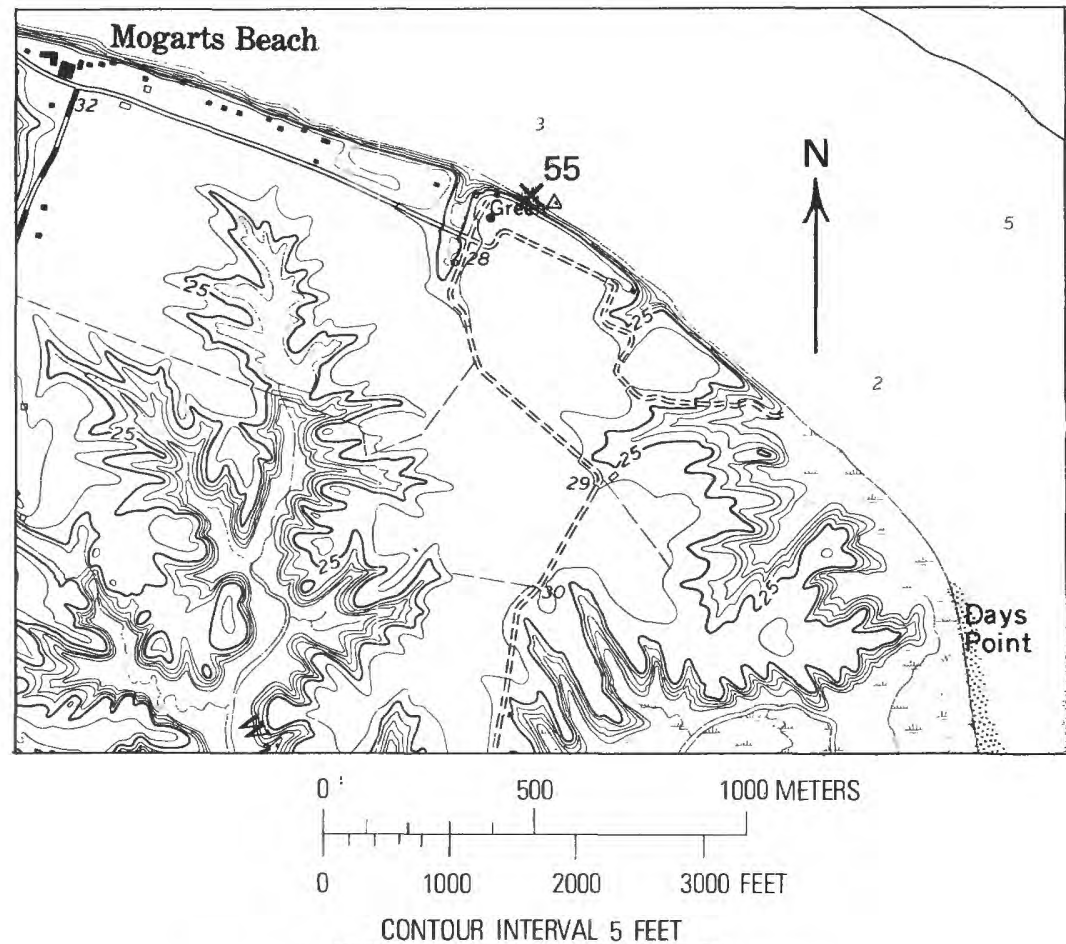

NATIONAL GEODETIC VERTICAL DATUM OF 1929

DEPTH CURVES IN FEET-DATUM IS MEAN LOWER LOW WATER SHDRELINE SHOWN REPRESENTS THE APPROXIMATE LINE OF MEAN HIGH WATER

Figure 17.-Location of the type section of the Morgarts Beach Member, Yorktown Formation.

Pleistocene(?):

Thickness

Tan sand and cobbles $\ldots \ldots \ldots \ldots \ldots \ldots \ldots . \ldots \ldots$

Yorktown Formation (in part):

Morgarts Beach Member:

Gray fine slightly sandy clay (tan where weathered) containing abundant small shell (Mulinia)

throughout $\ldots \ldots \ldots \ldots \ldots \ldots \ldots \ldots \ldots . \ldots \ldots$

Rushmere Member:

Blue-gray sandy shell clay, abundant

large shell ................... 2.1

- approximate mean low tide

Stratigraphic relationships.- The Morgarts Beach overlies the Rushmere Member and coincides in geographic extent with that unit (fig. 16). This relationship is conformable, 


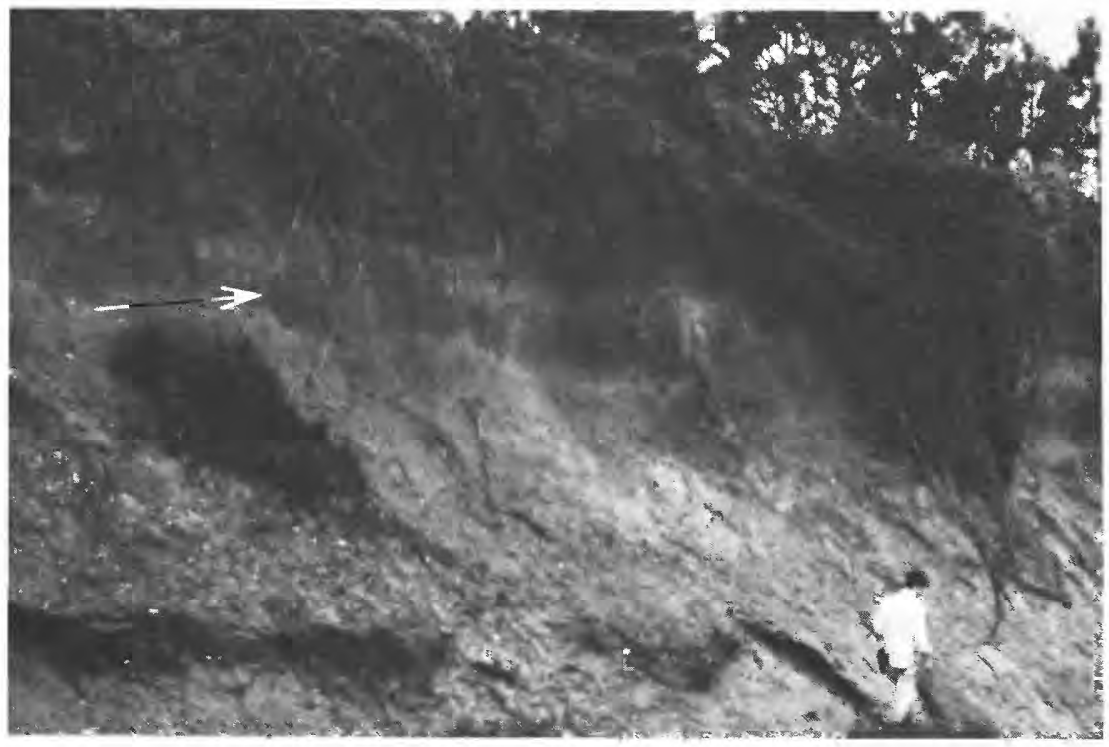

Figure 18.-Type locality of the Morgarts Beach Member and closeup of this member at locality 61 (Rushmere).

and in a few places the contact is gradational. The Morgarts Beach may be seen overlying the Rushmere near St. Stephens, King and Queen County, Va. (loc. 44), along the right bank of the James River near Rushmere, Isle of Wight County, Va. (loc. 61), at Grove Wharf, left bank of the James River, James City County, Va. (loc. 31), below the mouth of Baileys Creek on the right bank of the James River, Prince George County, Va. (loc. 13), along Lieutenant Run in Petersburg, Va. (loc. 43), and at Sycamore Bend, Nottoway River, Southampton County, Va. (loc. 50). The two members may also be seen in the vicinity of Murfreesboro, right bank of the Meherrin River, Hertford County, N.C. (loc. 29). In all of these locations, the underlying Rushmere Member is more arenaceous and contains abundant mollusks. The Morgarts Beach is distinguished by its fine, clayey lithology and abundance of small bivalves (Mulinia congesta). The Morgarts Beach conforms to the same strike and dip as the underlying Rushmere and attains an outcrop thickness of $6 \mathrm{~m}$.

Paleogeography.- The Morgarts Beach occupies the same area as the Rushmere in Virginia and northeast North Carolina (fig. 16). South of this area, it loses its identity and probably grades into the lithology of the Rushmere Member. 

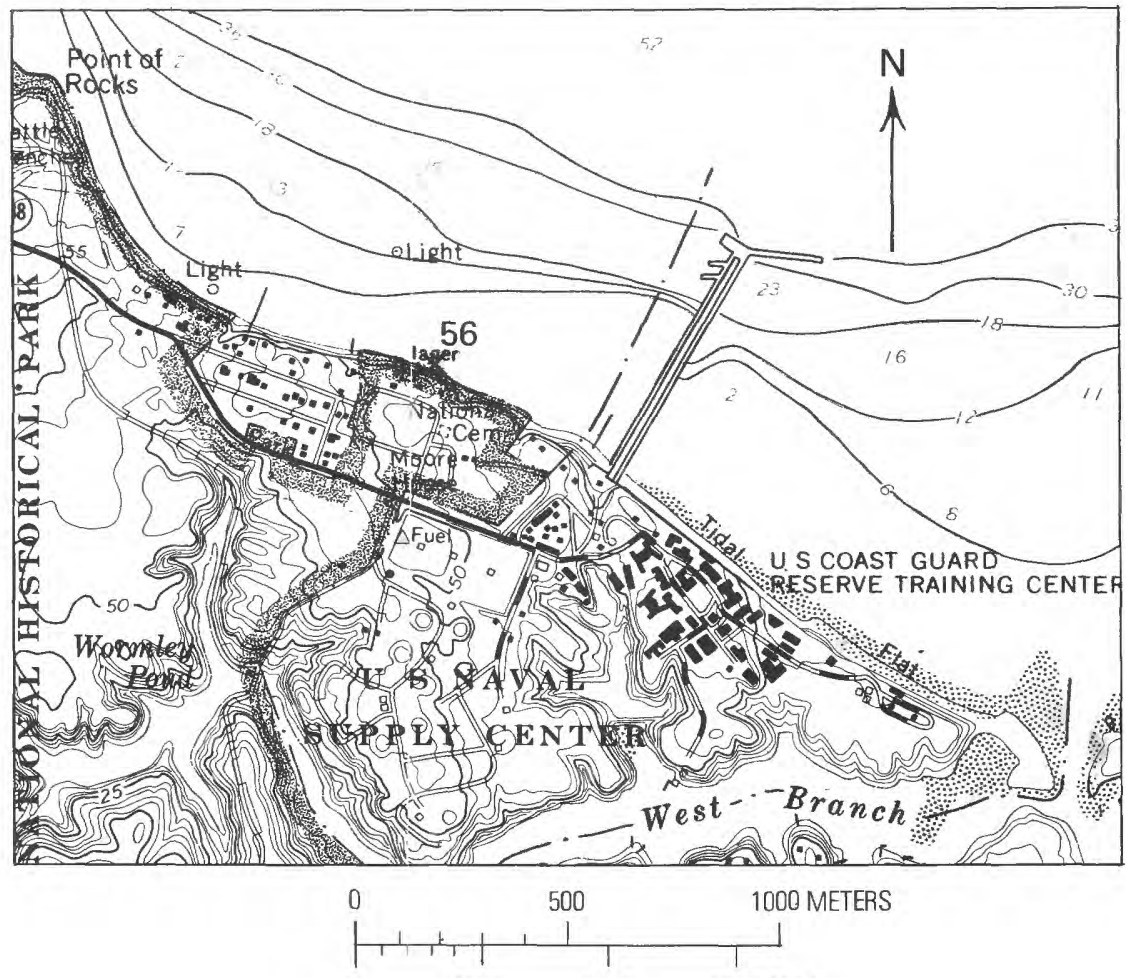

\section{$0 \quad 1000 \quad 2000 \quad 3000$ FEET}

CONTOUR INTERVAL 5 FEET

NATIJNAL GEODETIC VERTICAL DATUM OF 1929

DEPTH CURVES IN FEET-DATUM IS MEAN LOWER LOW WATEP

SHORELINE SHOWN REPRESENTS THE APPROXIMATE LNE OF MEAN HIGH WATER

Figure 19.-Location of type section Moore House Member, Yorktown Formation.

Paleoenvironment.- Although the clayey beds of the Morgarts Beach were deposited behind protective barrier bars, there is no evidence of lowered salinities. Normal marine conditions apparently prevailed while fine clayey sediments formed a suitable substrate for the bivalve, Mulinia congesta. In many areas, this species dominated the molluscan assemblage and is found in very high densities. Other forms commonly found with Mulinia include Yoldia sp., Nuculana sp., Spisula delumbis and Turritella alticostata.

\section{Moore House Member}

Definition and Description.- The Moore House Member is herein named for exposures on the York River at Moore House, Yorktown Battlefield Park, York County, Va. (loc. 56) (fig. 19, 20). 


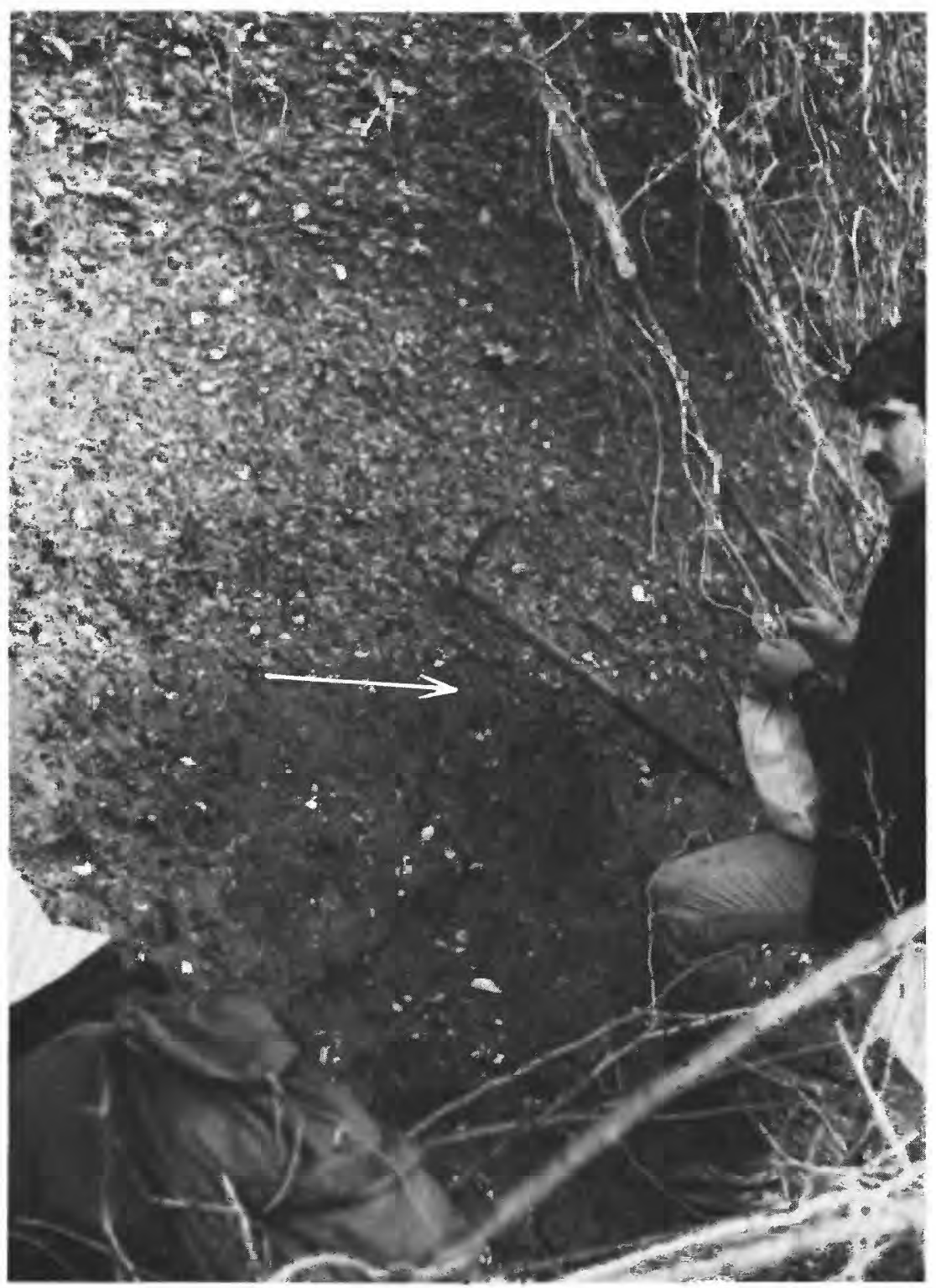

Figure 20.-Type locality of the Moore House Member showing the very shelly sands of the Moore House Member overlying the siltier Morgarts Beach Member.

The Moore House Member, representing the regressive phase of the Yorktown Formation, reflects a renewal of higher 
current and wave energy conditions. The member consists of sandy shell beds and cross-bedded shell hash and locally is cemented to form a very indurated rock.

Locality 56. Measured type section of the Moore House Member of the Yorktown Formation. Bluffs at the Moore House, right bank of the York River, in the Colonial National Historical Park, York County, Va. (Poquoson West 7 1/2-min quad).

$\frac{\text { Thickness }}{(\mathrm{m})}$

Yorktown Formation (in part):

Moore House Member:

Orange fragmental shell hash, extremely

calcareous but containing some fine quartz

sand; bryozoan and molluscan fragments

abundant . . . . . . . . . . . . . . 1.0

Tan clayey highly calcareous sand containing

abundant mollusks (Crepidula, oysters,

pectens), foraminifers, and ostracodes.

Sand is phosphatic, glauconitic, fine

grained, but somewhat poorly sorted

in places $\ldots \ldots \ldots \ldots \ldots \ldots \ldots \ldots . \ldots . \ldots . \ldots$

Slump:

Lower outcrop surface obscured by

slump and by $2.1 \mathrm{~m}$ of riprap ........ 3.7

- approximate mean low-tide-level-

Stratigraphic relationships.- The Moore House Member conformably overlies the Morgarts Beach Member in its outcrop area. The lower contacts of the Moore House, in some areas, are gradational with the underlying Morgarts Beach Member, but in most areas the transition is abrupt. The Moore House Member may be seen to overlie the Morgarts Beach Member from Morgarts Beach (loc. 55) to the vicinity of Rushmere on the right bank of the James River, Isle of Wight County, Va. (loc. 61), at Grove Wharf, left bank of the James River, James City County, Va. (loc. 31), and below Yorktown from Cornwallis Cave (loc. 65) to the Moore House, right bank of the York River, York County, Va. (loc. 56). At the abandoned Lone Star Cement Quarry near Chuckatuck, Nansemond County, Va. (loc. 58), small remnants of the Moore House overlie the cross-bedded shell beds of the Chuckatuck bar system. The Moore House strikes northeast-southwest and dips at approximately $5 \mathrm{~m} / \mathrm{km}$, except locally where underlying structures affect the regional dip. The maximum thickness of this member in outcrop is $6 \mathrm{~m}$.

Paleogeography.- The Moore House Member is found only east of the Surry Scarp, a feature which may have been cut at this time (fig. 21). The member is not known from North 


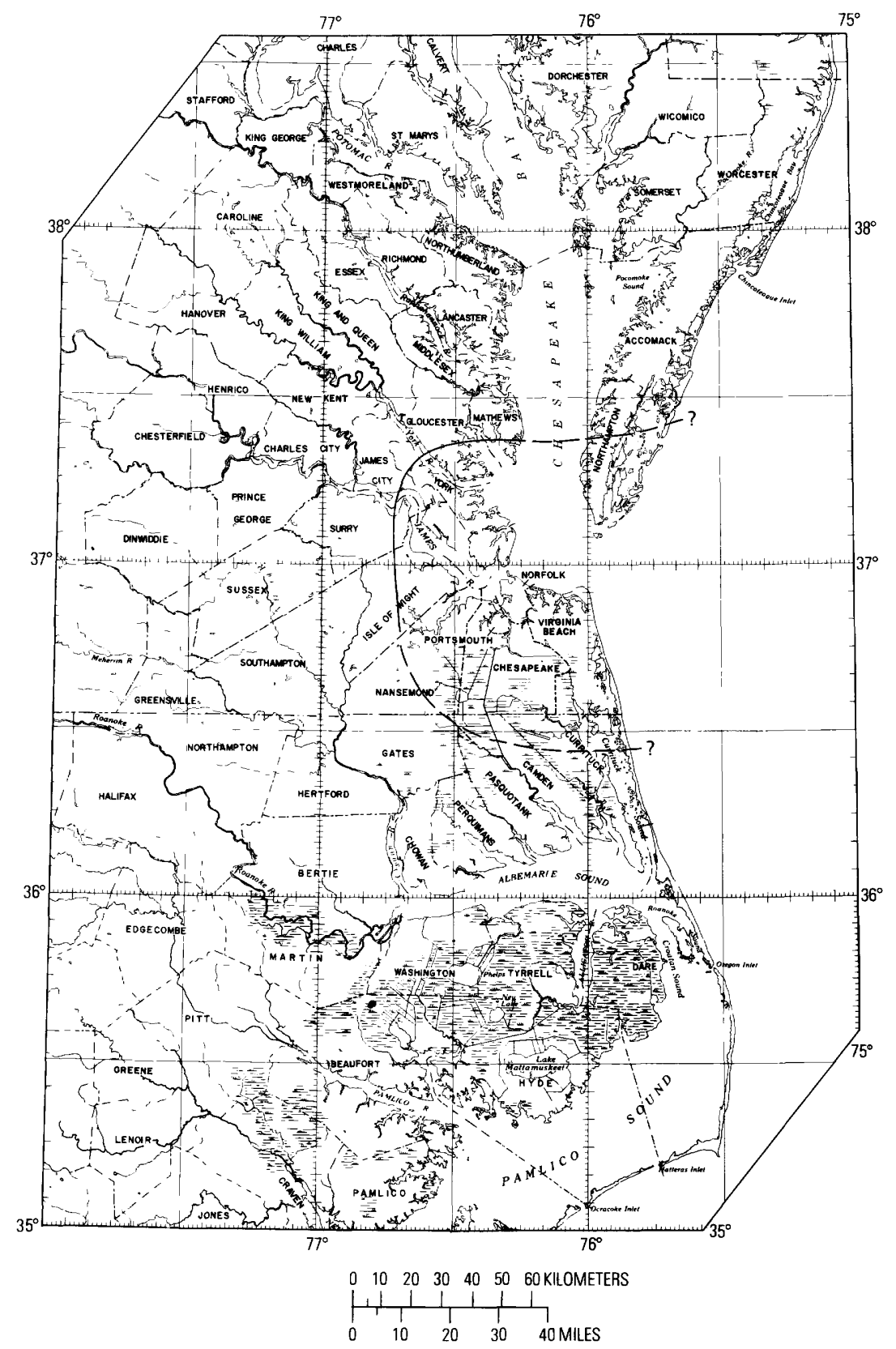

Figure 21.-Map showing extent of outcrops in Moore House Member of the Yorktown Formation. 
Carolina and is confined to the southeastern part of the Virginia coastal plain.

Paleoenvironment.- The Moore House Member reflects a progressively shallowing, regressive sea. Molluscan assemblages indicate normal salinities, but some of the highest beds in the Williamsburg area (loc. 66) contain a few brackish-water mollusks. Locally large offshore bars were the site of rapid, large-scale, cross-bedded sand deposition.

Molluscan Assemblages.-The following mollusks are commonly found in the Rushmere, Morgarts Beach, and Moore House Members of the Yorktown Formation:

Scapharca staminea (Say, 1832)

Anadara scalaris (Conrad,1843)

Anadara lienosa (Say, 1832)

Granoarca propatula (Conrad, 1843)

Anadara improcera (Conrad, 1845)

Noetia incile (Say, 1824)

Striarca centenaria (Say, 1824)

Glycymeris tuomeyi (Dall, 1898)

Glycymer is americana (DeFrance, 1826)

Glycymer is arata (Conrad, 1841)

Pecten ocklockoneensis (Mansfield, 1932)

Placopecten sp.

Amusium mortoni (Ravenel, 1844)

Chesapec ten madisonius (Say, 1824)

Chesapecten septenarius (Say, 1824)

Pecten decenmarius Conrad, 1834

$\overline{\text { Pecten }}$ rogersii (Conrad, 1834)

Pecten eboreus Conrad, 1833

Argopecten vicenarius (Conrad, 1843)

Plicatula marginata Say, 1824

Ostrea sculpturata Conrad, 1840

Ostrea raveneliana Tuomey \& Holmes, 1855

Stewartia anodonta (Say, 1824)

Lucinoma contracta (Say, 1824)

Chama congregata Conrad, 1833

Pseudochama corticosa (Conrad, 1833)

Carditamera arata (Conrad, 1832)

Astarte undulata Say, 1824

Astarte concentrica Conrad, 1834

Astarte symmetrica Conrad, 1834

Crassatella undulata Say, 1824

Cardium acutilaqueatum Conrad, 1839

Planicardium virginianum (Conrad, 1839)

Spisula delumbis (Conrad, 1832)

Spisula harrisi (Olsson, 1914) 
Spisula duplinensis (Dall, 1898)

Spisula modicella (Conrad, 1833)

Mulinia congesta (Conrad, 1833)

Rangia clathrodonta (Conrad, 1833)

Glossus fraterna (Say, 1824)

Macrocallista albaria (Say, 1834)

Dosinia acetabulum (Conrad, 1832)

Lirophora sp.

Chione cortinaria (Rogers \& Rogers, 1835)

Mercenaria tridacnoides (Lamarck, 1818)

Pleiorytis centenaria (Conrad, 1833)

Panopea goldfussii Wagner, 1839

Panopea reflexa Say, 1824

Kuphus fistula (H. C. Lea, 1843)

Diadora redimicula (Say, 1824)

Turritella alticostata Conrad, 1834

Petaloconchus sculpturatus (H. C. Lea, 1843)

Lirosoma sp.

Pterorytis umbrifer (Conrad, 1832)

Ecphora quadricostata (Say, 1824)

Urosalpinx suffolkensis Gardner (1948)

Urosalpinx trossulus (Conrad, 1832)

Peristernia filicatum (Conrad, 1843)

Ptychosalpinx fossulatum (Conrad, 1843)

Ptychosalpinx laqueatum (Conrad, 1832)

Ptychosalpinx altile (Conrad, 1832)

Busycon maximum (Conrad, 1839)

Busycotypus incile (Conrad, 1833)

Scaphella solitaria ssp.

Scaphella sp.

Fusinus exilis (Conrad, 1832)

Faciolaria rhomboidea Rogers \& Rogers, 1835

Oliva canaliculata H. C. Lea, 1845

Conus marylandicus Green, 1830

Conus adversarius Conrad, 1840

Cymatosyrinx lunatum (H. C. Lea, 1843)

\section{SUMMARY OF DEPOSITIONAL AND STRUCTURAL HISTORY}

Schematic sections were prepared showing the trends of various units outcropping along parts of major rivers. Figure 22 shows sections of the Chesapeake Group as seen along the Potomac River, the Rappahannock River, the Pamunkey River, and the James River. All sections have been drawn to the same scale so that dips and thicknesses may be compared. The locality numbers are shown in figure 1. Distances between each of the localities were measured essentially at right angles to the 


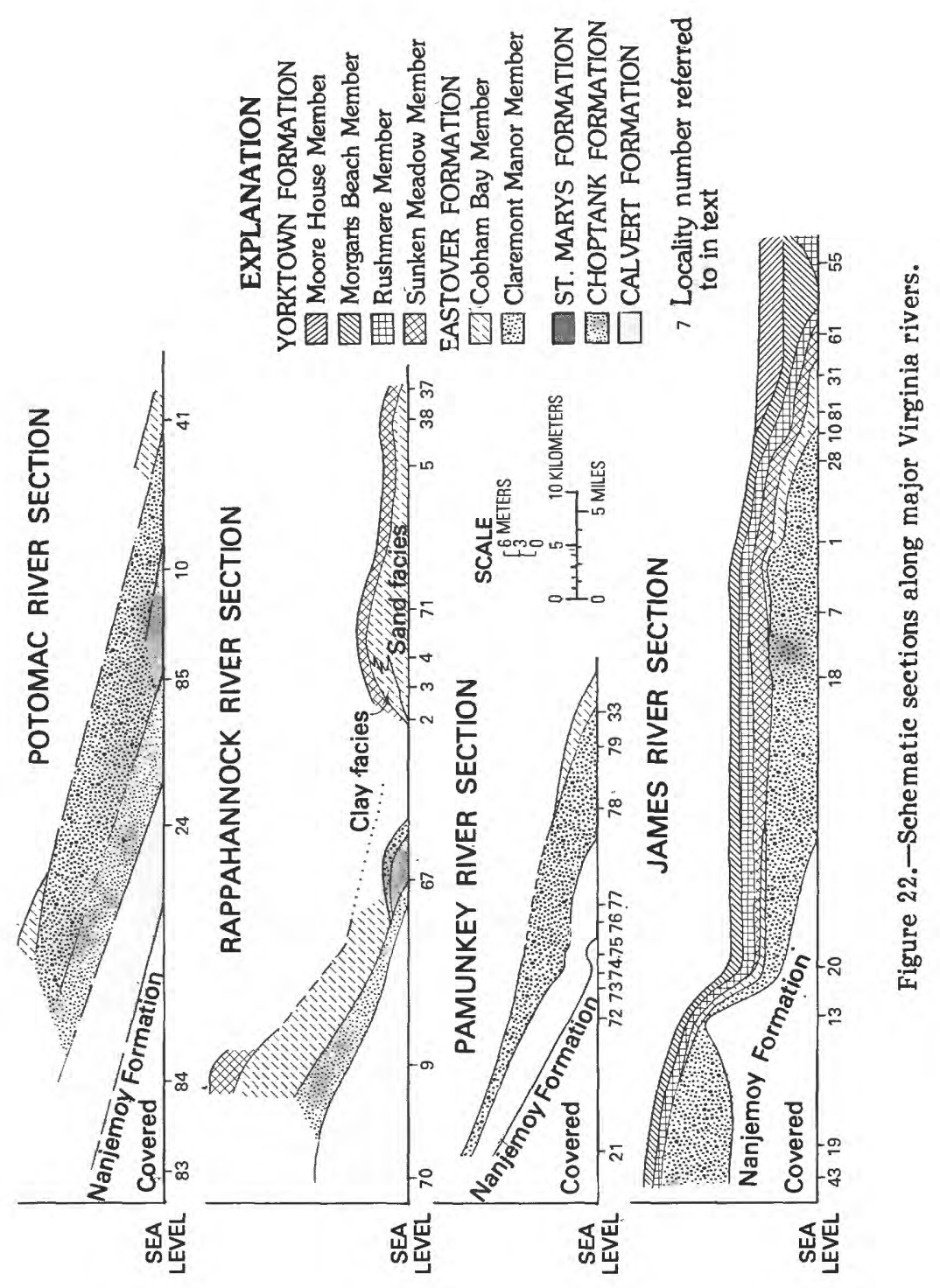



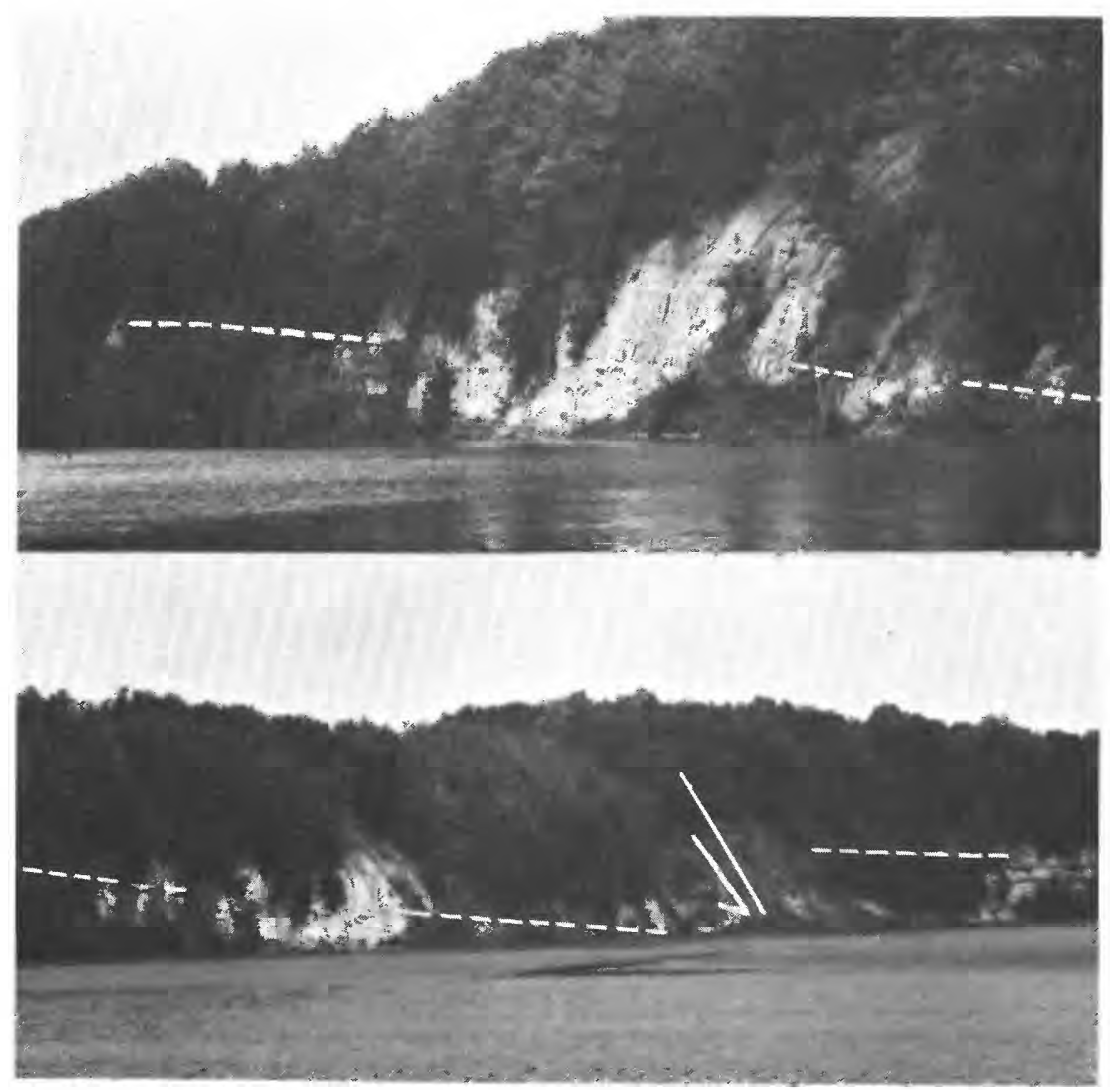

Figure 23.-View of the cliffs just below Wilmont Wharf (loc. 70) on the Rappahannock River showing steeply dipping beds upriver and nearly horizontal beds downstream.

strike. The river sections tend to parallel the direction of the dip. These illustrate positions of reverse dip, geologic highs, and regions of low-angle dipping beds. These profiles and the inland outcrops, shown in figure 1, enabled delimitation of certain coastal plain structural features. The most striking structural feature is found at the boundary of King George and Westmoreland counties along the Rappahannock River, Va. (fig. 23), where a fault is exposed. The fault is a half graben striking $\mathrm{N} 70^{\circ} \mathrm{W}$. Beds on the southwest side of the fault dip steeply to the southeast at an angle of $9^{\circ}$. Beds on the northeastern side of the fault dip downriver at a very low angle. At this section, Eocene and lower and middle Miocene (Calvert Formation) beds are faulted. The fault is herein named the Wilmont Fault from the name of the old wharf at this locality.

Other structural movement is suggested for locations where beds were deposited with a westward dip. Presumably, 
CHESAPEAKE GROUP, MIDDLE ATLANTIC COASTAL PLAIN D5 1

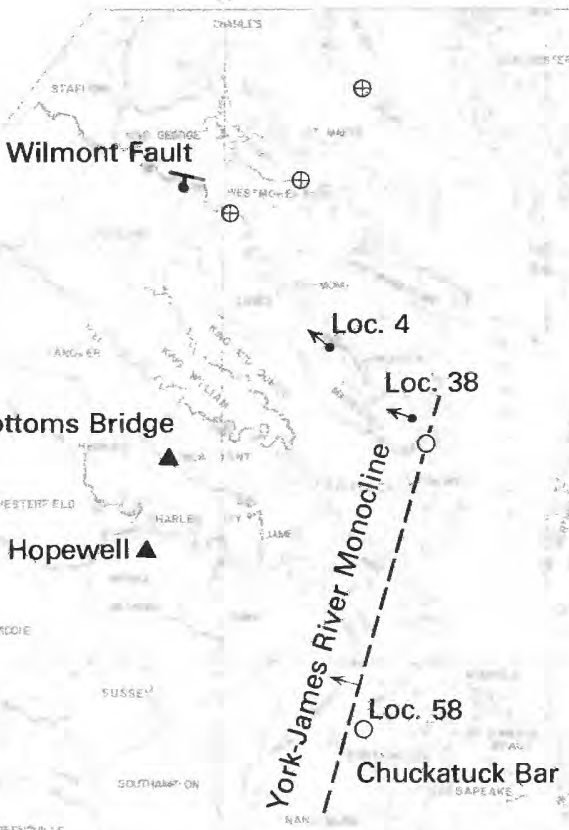

EXPLANATION

$\Delta$ Structurally positive area

1 Monocline-Arrows point down dip

\& Fault-Bar and ball on downthrown side

$\oplus$ Regions of low dip

OLocations of shoaling deposits

$\leftarrow$ Regions of westward dip

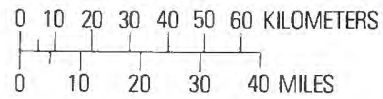

Figure 24.--Location of structural features in part of the Virginia Coastal Plain.

westward dip is caused by uplift to the east that created high areas. Those highs controlled sedimentary patterns within the particular formations. Three major areas have westwarddipping beds: the Bowlers Wharf area of the Rappahannock River, the lower York peninsula, and the lower James River 
area. In the York and James River area (fig. 24), Yorktown beds dip to the west (upriver). Locations of shoaling within the Yorktown Formation on the Piankatank River (fig. 12) and in the northeastern part of Nansemond County (loc. 58) are in line with the eastern limit of reverse dip areas, suggesting a structural feature that trends approximately $\mathrm{N} 15^{\circ} \mathrm{E}$. This feature is termed the York-James River monocline because it is a steplike feature. This trend is virtually essentially parallel to the present surface expression of the southern Delmarva Peninsula and indicates a possible relationship between the structural controls of the two areas. It should be noted that the region of shoaling in Nansemond County (loc. 58) is in close proximity to a basement graben indicated by Brown and others (1972, pl. 5). These shoaling areas are typified by cross-bedded shell hashes that contain abundant Ophiomorpha burrows. The units of the Yorktown in which this shoaling occurs correlate with deeperwater beds to the west and are unrelated to the regressive phase of the later parts of the Yorktown.

Within the Cobham Bay Member of the Eastover Formation, westward dipping beds may be seen for about $5 \mathrm{~km}$ in the vicinity of Bowlers Wharf on the Rappahannock River. The dip appears to be primary and to reflect patterns of sedimentation within the member. Beds are progressively sandier to the east. Behind this high area, clay accumulated during Cobham Bay time west of Bayport (loc. 4). This suggests that structural activity created a high area which locally controlled sedimentary patterns within the Cobham Bay Member. Brown and others (1972, pl. 5) also indicated a presence of a basement graben in this area.

Farther downriver on the Rappahannock River, beds of the Cobham Bay Member also dip steeply to the west in the vicinity of Burhans Wharf (loc. 38). There the bivalve Isognomon is commonly found articulated with the ligamented area facing updip. The dip reflects sedimentary patterns within the member that are possibly related to structural controls. These beds must have been originally deposited at a steep angle (see fig. 25).

In addition to these locations of westwardly dipping units, there are regions over which the dip in particular units is extremely low. These regions are indicated in figure 24 and include the Calvert and Choptank beds on the Patuxent River and on the Rappahannock River. Farther south are two areas where the angle of the dip is very low within the Cobham Bay beds but extremely high within the preceding Claremont Manor beds. On the Mattaponi River from White Oak Landing to the Mattaponi Indian Reservation, a distance of about $5 \mathrm{~km}$, the upper surface of the Claremont Manor Member drops about $12 \mathrm{~m}$ in elevation. Along the James River from Burrowsville to 


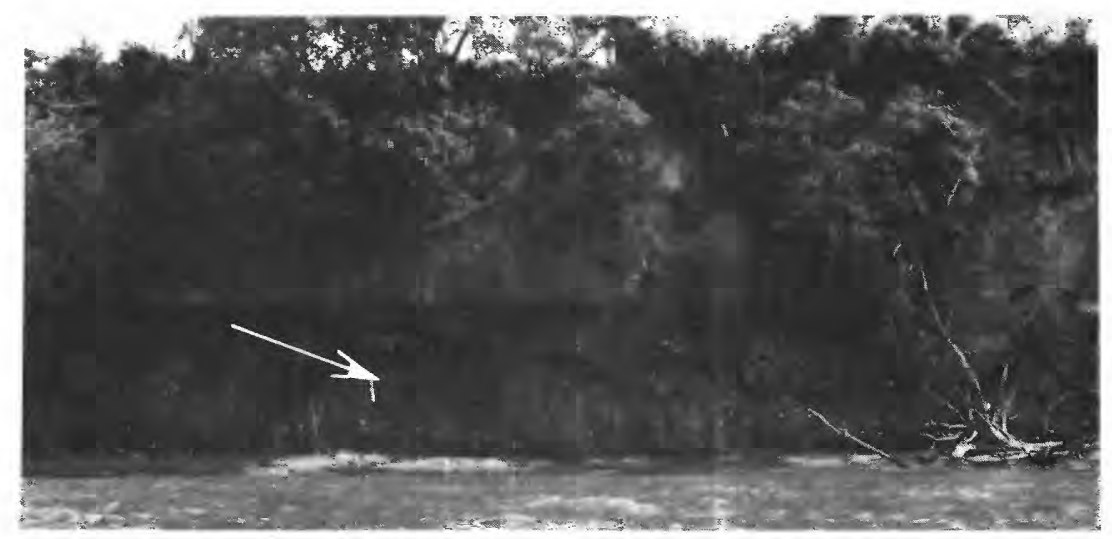

Figure 25.--View of the cliffs at Burhans Wharf (loc. 38) on the Rappahannock River showing the beds dipping steeply upriver (northwest).

Claremont Wharf, a distance of $12 \mathrm{~km}$, the lower surface of Claremont Manor Member drops from sea level to $20 \mathrm{~m}$ below sea level. At the Mattaponi and at the James River locations, the Cobham Bay Member is extremely thin as the areas apparently became relatively positive after Claremont Manor time, and remained positive during Yorktown time.

Cobham Bay beds also thin over two other high areas. At Hopewell, the entire Eastover Formation pinches out on top of glauconitic Eocene sands and the Yorktown beds are extremely thin. In close proximity to the west of Hopewell, Eocene beds can be seen at water level, and nearby to the west, Cretaceous outcrops are $24 \mathrm{~m}$ thick. This area at Hopewell is herein referred to as the Hopewell High.

Another high area occurring to the north of the Hopewell High is centered in the vicinity of Bottoms Bridge in eastern Henrico County. In that area, the Cobham Bay Member thins to $10 \mathrm{~cm}$ in thickness over a moderately thick Claremont Manor Member. This high area is herein referred to as the Bottoms Bridge High. This feature is suggested by the structural contour map of Cederstrom (p. 56, fig. 6) and in the basement maps of Brown and others $(1972$, pl. 5) that show a graben in the vicinity of this high area.

Regional structural activity is also indicated for the innermost parts of the Coastal Plain. The Miocene-Pliocene boundary at Petersburg is at $30 \mathrm{~m}$ elevation. bham Bay Member is extremely thin as the areas apparently became relatively positive after Claremont Manor time, and remained positive during Yorktown time. 
Cobham Bay beds also thin over two other high areas. At Hopewell, the entire Eastover Formation pinches out on top of glauconitic Eocene sands and the Yorktown beds are extremely thin. In close proximity to the west of Hopewell, Eocene beds can be seen at water level, and nearby to the west, Cretaceous outcrops are $24 \mathrm{~m}$ thick. This area at Hopewell is herein referred to as the Hopewell High.

Another high area occurring to the north of the Hopewell High is centered in the vicinity of Bottoms Bridge in eastern Henrico County. In that area, the Cobham Bay Member thins to $10 \mathrm{~cm}$ in thickness over a moderately thick Claremont Manor Member. This high area is herein referred to as the Bottoms Bridge High. This feature is suggested by the structural contour map of Cederstrom (p. 56, fig. 6) and in the basement maps of Brown and others $(1972, \mathrm{pl} .5)$ that show a graben in the vicinity of this high area.

Regional structural activity is also indicated for the innermost parts of the Coastal Plain. The Miocene-Pliocene boundary at Petersburg is at $30 \mathrm{~m}$ elevation. At Richmond, Miocene and Pliocene beds are absent, although the marine Cobham Bay Member is above $48 \mathrm{~m}$ elevation.

\section{LOCALITY REGISTER}

Locality, county, state, map reference: (USGS)

260251 1. $0.8 \mathrm{~km}$ above Mount Pleasant, right bank of James River, Surry County, Va., Surry 7 1/2 min quad.

260262 2. $2.7 \mathrm{~km}$ below Bowlers Wharf, right bank of Rappahannock River, Essex County, Va., Morattico $71 / 2$ min quad.

26027 3. Laytons Landing, right bank of the Rappahannock River, Es sex County, Va., Morattico 7 1/2 min quad.

26028 4. Bayport, right bank of the Rappahannock River, Middlesex County, Va., Morattico $71 / 2$ min quad.

26029 5. Right bank of Urbanna Creek, $0.5 \mathrm{~km}$ above the Rte. 227 Bridge, Middlesex County, Va., Urbanna $71 / 2$ min quad.

26030 6. Warren Bros., Henrico Pit, $0.8 \mathrm{~km} \mathrm{SW}$ of intersection of Rte. 33 and Rte. 60, near Bottom's Bridge, south of the Chickahominy River, Henrico County, Va., Quinton 7 1/2 min quad.

26031 7. Just below the mouth of Sunken Meadow Creek, right bank of the James River, Surry County, Va., Claremont $71 / 2$ min quad. 
26032 8. Behind (just east of) the Richmond City jail at the corner of Fairfield Ave. and 17th St., Richmond, Va., Richmond $71 / 2$ min quad.

26033 9. Fones Cliffs, $1 \mathrm{~km}$ above Carters Wharf, left bank of the Rappahannock River, Richmond County Va., Champlain $71 / 2$ min quad.

26034 10. Carthagena Creek, $1 \mathrm{~km}$ above the Rte. 244 Bridge, in a western branch, St. Marys County, Md., St. Marys City $71 / 2$ min quad.

26035 11. Rickahock, left bank of the Mattaponi River, King and Queen County, Va., King and Queen Court House $71 / 2$ min quad.

26036 12. Elsing Green, left bank of the Pamunkey River, King William County, Va., Tunstall 7 1/2 min quad.

26037 13. Just below the mouth of Baileys Creek, right bank of the James River, in gully at dead end of Rte. 644, Prince George County, Va., Westover 7 $1 / 2$ min quad.

26038 14. Colonial Heights, in creek at dead end of Chesterfield Ave., Chesterfield County, Va., Petersburg $71 / 2$ min quad.

26039 15. Boat launching ramp just below the Rte. 258 bridge on the left bank of the Meherrin River at Murfreesboro, Hertford County, N.C., unmapped quad.

26040 16. Just below the Wilcox Lake Spillway, Petersburg, Va., Petersburg $71 / 2$ min quad.

26041 17. Just above the mouth of Sunken Meadow Creek, right bank of the James River, Surry County, Va., Claremont $71 / 2$ min quad.

26042 18. Bluffs at, and just below, the mouth of Upper Chippokes Creek at Claremont Manor, $1.5 \mathrm{~km}$ northwest of Claremont, right bank of the James River, Surry County, Va., Claremont 7 1/2 min quad.

26043 19. Poor Creek at Fort Stedman, Petersburg National Battlefield Park, Prince George County, Va., Prince George $71 / 2$ min quad.

$2604420.1 .4 \mathrm{~km}$ above Coggins Point, right bank of the James River at Tar Bay, Prince George County, Va., Westover $71 / 2$ min quad.

26045 21. Gravatts Mill on Millpon Creek, King William County, Va., Hanover $71 / 2$ min quad.

26046 22. White Oak Landing, right bank of Mattaponi River, King William County, Va., King and Queen Court House $71 / 2$ min quad. 
26047 23. Mantua Landing, right bank of Mattaponi River, King William County, Va., King and Queen Court House $71 / 2$ min quad.

26048 24. Westmoreland State Park, at the eastern end of Horsehead Cliffs, right bank of the Potomac River, Westmoreland County, Va., Stratford Hall $71 / 2$ min quad.

$2604925 . \quad 0.1 \mathrm{~km}$ west of Rte. 31 and Rte. 604 intersection and $1.5 \mathrm{~km} \mathrm{NW}$ of Rte. 604, Sussex County, Va., Dendron $71 / 2$ min quad.

2605026 . $0.2 \mathrm{~km}$ above Rte. 647 Bridge at Reedy Mill, left bank of Mattaponi River, Caroline County, Va., Penola $71 / 2$ min quad.

26051 27. Well at Crisfield, Somerset Co., Md. N. H. Darton, collector, 1891. Burton Water Co., Drillers.

2605228 . $0.8 \mathrm{~km}$ below Cobham Wharf, right bank of James River, Surry County, Va., Surry $71 / 2$ min quad.

26053 29. Bluffs just above Murfreesboro, right bank of Meherrin River, Hertford County, N.C., unmapped quad.

2605430 . Right bank of the Nottoway River, $100 \mathrm{~m}$ below Rte. 631 Bridge, Sussex County, Va., Sebrell 7 $1 / 2$ min quad.

26055 31. Grove Wharf, left bank of James River, $8 \mathrm{~km}$ below mouth of Grove Creek, James City County, Va., Hog Island $71 / 2$ min quad.

2605632 . $0.3 \mathrm{~km}$ southwest of Tunstall Station, in a deep ravine and tributary to Black Creek, New Kent County, Va., Tunstall $71 / 2$ min quad.

2605733 . $2.1 \mathrm{~km}$ northwest of Romancoke, left bank of the Pamunkey River, King William County, Va., West Point $71 / 2$ min quad.

26058 34. Madison Creek, $1.2 \mathrm{~km}$ northwest of Colosse Baptist Church (on Rte. 30), King Williams County, Va., King and Queen Court House 7 1/2 min quad.

2605935 . $0.8 \mathrm{~km}$ above Wakema, right bank of the Mattaponi River, King William County, Va., King and Queen Court House $71 / 2$ min quad.

$2606036 . \quad$ Courthouse Landing, left bank of the Mattaponi River, King and Queen County, Va., King and Queen Court House 7 1/2 min quad.

26061 37. Just below mouth of Whiting Creek, right bank of Rappahannock River, Middlesex County, Va., Saluda $71 / 2$ min quad.

26062 38. Burhans Wharf, $1.6 \mathrm{~km}$ above the mouth of Whiting Creek, right bank of the Rappahannock 
River, Middlesex County, Va., Saluda 7 1/2 min quad.

26063 39. Freeport, just above the mouth of Harper Creek, right bank of the Piankatank River, Gloucester County, Va., Saluda $71 / 2$ min quad.

26064 40. Blands Wharf, just below the mouth of Harper Creek, right bank of the Piankatank River, Gloucester County, Va., Saluda $71 / 2$ min quad.

26065 41. Along Hull Creek, right bank of the Potomac River, Northumberland County, Va., Heathsville $71 / 2$ min quad.

26066 42. $1.3 \mathrm{~km}$ below mouth of Sunken Meadow Creek, right bank of the James River, Surry County, Va., Claremont $71 / 2$ min quad.

26067 43. Lieutenant Run, upstream of the Baylor Lane Bridge, Petersburg, Va., Petersburg $71 / 2 \mathrm{~min}$ quad.

26068 44. Fleets Mill Pond, $1.5 \mathrm{~km}$ southeast of Shepherds Church and Rte. 360 on Rte. 631, King and Queen County, Va., Aylett $71 / 2$ min quad.

26069 45. $0.1 \mathrm{~km}$ northeast of Pauls Cross Roads, in roadcut of Rte. 360, just south of Piscataway Creek, Essex County, Va., Millers Tavern 7 1/2 min quad.

2607046 . $0.1 \mathrm{~km}$ below the mouth of Felgates Creek, right bank of the York River, York County, Va., Clay Bank $71 / 2$ min quad.

26071 47. Right bank of the Trent River, just below the mouth of Brice Creek, Jones County, N.C., New Bern $71 / 2$ min quad.

2607248 . $0.1 \mathrm{~km}$ below Mill Creek, left bank of the Neuse River, Pamlico County, N.C., Cherry Point 7 1/2 min quad.

26073 49. Texasgulf, Inc., phosphate pit north of Aurora, right bank of the Pamlico River, Beaufort County, N.C., Bath $71 / 2$ min quad.

2607450 . Left bank of the Nottoway River at Sycamore Bend, Southampton County, Va., Franklin 7 1/2 min quad.

26075 51. Trego Quarry, $2.8 \mathrm{~km}$ WSW of Skippers, Greensville County, Va., Skippers $71 / 2$ min quad.

26076 52. Banks of a northward flowing tributary to Quankey Creek, north side of North Carolina Rte. $561,0.8 \mathrm{~km}$ west of railroad crossing over Rte. 651 in Halifax, Halifax County, N.C., unmapped quad.

26077 53. Colerain Landing, $1.6 \mathrm{~km}$ east of Colerain, right bank of the Chowan River, Bertie County, N.C., unmapped quad. 
26078 54. Edenhouse Landing, $0.8 \mathrm{~km}$ above Edenhouse Point, right bank of the Chowan River, Bertie County, N.C., Edenton 15 min quad.

2607955 . $1.0 \mathrm{~km}$ below Morgarts Beach, right bank of the James River, Isle of Wight County, Va., Mulberry Island $71 / 2$ min quad.

26080 56. Bluffs at the Moore House, right bank of the York River, in the Colonial National Historical Park, York County, Va., Poquoson West 7 1/2 min quad.

26081 57. Point of Rocks, $1.2 \mathrm{~km}$ below Yorktown on the right bank of the York River, York County, Va., Poquoson West $71 / 2 \mathrm{~min}$ quad.

26082 58. Lone Star Cement Co. Quarry (abandoned), 0.1 $\mathrm{km}$ north of Chuckatuck and east of Rtes. 10 and 32, Nansemond County, Va., Chuckatuck 7 1/2 min quad.

26083 59. Glebe Neck, $0.1 \mathrm{~km}$ below the mouth of Wilton Creek, left bank of the Piankatank River, Middlesex County, Va., Wilton $71 / 2$ min quad.

2608460 . Roadcut $0.6 \mathrm{~km}$ northeast of Manquin on Rte. 360 , King William County, Va., Manquin $71 / 2$ min quad.

2608561 . $0.7 \mathrm{~km}$ east of Rushmere, right bank of the James River, Isle of Wight County, Va., Bacons Castle $71 / 2$ min quad.

26086 62. $1.2 \mathrm{~km}$ east of Palmyra, right bank of the Roanoke River, Martin County, N.C., Palmyra 7 $1 / 2$ min quad.

26087 63. Biddle Landing, right bank of the Neuse River, $3.2 \mathrm{~km}$ north of Ft. Barnwell, Craven County, N.C., Ayden 15 min quad.

26088 64. Martin Marietta Co., New Bern Quarry, northwest of New Bern, $0.8 \mathrm{~km}$ northeast of Rte. 55 on County Road 1402, Craven County, N.C., New Bern 15 min quad.

26089 65. Cornwallis' Cave at Yorktown Beach, right bank of the York River, York County, Va., Yorktown 7 $1 / 2$ min quad.

2609066 . Ravine leading down to Matoaka Lake, $0.2 \mathrm{~km}$ west of Cary Stadium, Williamsburg, Va., Williamsburg $71 / 2$ min quad.

26091 67. Essex Mill, $2.2 \mathrm{~km}$ west of Dunnsville, Essex County, Va., Dunnsville $71 / 2$ min quad.

26092 68. Mt. Airy Mill Pond, just off Rte. 621, Richmond County, Va., Tappahnnock $71 / 2$ min quad.

26093 69. Just south of Connellee Mill Pond in roadcut on Rte. 621, Richmond County, Va., Tappahannock 7 $1 / 2$ min quad. 
2609470 . Wilmont Wharf, left bank of Rappahannock River, King George County, Va., Rollins Fork 7 $1 / 2$ min quad.

26095 71. Butylo, right bank of the Rappahannock River, Middlesex County, Va., Morattico 7 1/2 min quad.

26096 72. Roadcut of Rte. 360 at the Pamunkey River, King William County, Va., Old Church $71 / 2 \mathrm{~min}$ quad.

26097 73. Sycamore bend, right bank of the Pamunkey River, Hanover County, Va., Old Church 7 1/2 min quad.

26098 74. Piping Tree Ferry, left bank of the Pamunkey River, King William County, Va., King William 7 $1 / 2$ min quad.

26099 75. Matadequin Creek, right bank of Pamunkey River, New Kent County, Va., Tunstall 7 1/2 min quad.

26100 76. Montague Landing, left bank of the Pamunkey River, King William County, Va., Tunstall 7 1/2 min quad.

26101 77. Below Putneys Mill at end of Rte. 607, right bank Pamunkey River, New Kent County, Va., Tunstall $71 / 2$ min quad.

$2610278.1 .6 \mathrm{~km}$ below White Landing, left bank of the Pamunkey River, King William County, Va., New Kent $71 / 2$ min quad.

26103 79. Just below Brickhouse Landing, left bank of the Pamunkey River, King William County, Va., New Kent $71 / 2$ min quad.

26104 80. Chippokes Plantation State Park, right bank of the James River, Surry County, Va., Cobham Bay $71 / 2$ min quad.

$2610581.1 \mathrm{~km}$ below Kingsmill Wharf, James City County, Va., Cobham Bay 7 1/2 min quad.

26106 82. Martiau $1.6 \mathrm{~km}$ below Horse Pt., left bank of the Piankatank River, Middlesex County, Va., Wilton $71 / 2$ min quad.

$2610783.1 .6 \mathrm{~km}$ above Popes Creek, left bank of the Potomac River, Charles County, Md., Mathias Point $71 / 2$ min quad.

26108 84. $2 \mathrm{~km}$ below Popes Creek, left bank of the Potomac River, Charles County, Md., Colonial Beach North $71 / 2$ min quad.

26109 85. Coles Point, right bank of the Potomac River, Westmoreland County, Va., St. Clements Island 7 $1 / 2$ min quad.

$2611086.1 \mathrm{~km}$ below Eastover, right bank of the James River, Surry County, Va., Claremont 7 1/2 min quad. 
26111 87. Haynes Mill, where Rte. 614 crosses Carter Creek, Gloucester County, Va., Clay Bank 7 1/2 min quad.

26112 88. Rices Borrow Pit, off Harris Creek Road in Hampton, Va., Hampton $71 / 2$ min quad.

$2611389.1 \mathrm{~km}$ above Morgarts Beach, right bank of the James River, Isle of Wight County, Va., Mulberry Island $71 / 2 \mathrm{~min}$ quad.

2611490. Morgarts Beach, right bank of the James River, Isle of Wight County, Va., Mulberry Island $71 / 2$ min quad.

26115 91. Excavation for sewage treatment plant in Waverly, Sussex County, Va., Waverly $71 / 2 \mathrm{~min}$ quad.

\section{REFERENCES CITED}

Akers, W. H., 1972, Planktonic Foraminifera and biostratigraphy of some Neogene formation, northern Florida and Atlantic Coastal Plain: Tulane Studies in Geology and Paleontology, v. 9 , no. $1-4,139$ p.

Berggren, W. A., and van Couvering, J. A., 1974, The late Neogene Biostratigraphy, geochronology and paleoclimatology of the last 15 million years in marine and continental sequences: Palaeogeography, Palaeoclimatology, Palaeoecology, v. 16, no. 1-2, 216 p.

Brown, P. M., Miller, J. A., and Swain, F. M., 1972, Structural and stratigraphic framework, and spatial distribution of permeability of the Atlantic Coastal Plain, North Carolina to New York: U. S. Geological Survey Professional Paper 796, 79 p., 59 pl.

Clark, W.B., and Miller, B. L., 1906, A brief summary of geology of the Virginia Coastal Plain: Virginia Geological Survey Bulletin 2, pt. 1, p. 11-24.

1912, The physiography and geology of the Coastal Plain province of Virginia: Virginia Geological Survey Bulletin 4, p. 13-222.

Dall, W. H., and Harris, G. D., 1892, Correlation papers Neogene: U.S. Geological Survey Bulletin 84, 349 p.

Darton, N. H., 1891, Mesozoic and Cenozoic formation of eastern Virginia and Maryland: Geological Society of America Bulletin, v. 2, p. 431-450.

Gibson, T. G., 1970, Late Mesozoic-Cenozoic tectonic aspects of the Atlantic coastal margin: Geological Society of America Bulletin, v. 81 , no. 6 , p. 1813-1822.

1971, Miocene of the Middle Atlantic Coastal Plain, in Gernant, R. E., Gibson, T. G., and Whitmore, F. C., Jr., 
Environmental history of Maryland Miocene, Field Trip 5 of Geological Society of America, Annual Meeting: Maryland Geological Survey Guidebook 3, p. 1-15.

Goddard, E. N., and others, 1948, Rock-color chart: Washington, D. C., National Research Council; reprinted by Geological Society of America, 1951, 1963, 1970, 6 p.

Johnson, G. H., and Goodwin, B. K., 1969, Guidebook to the geology of the York-James Peninsula and south bank of the James River-Atlantic Coastal Plain Geologic Association, 10th Annual Field Conference, and 1st Annual Virginia Geologic Field Conference: Williamsburg, Va., College of William and Mary (Department of Geology Guidebook 1), 33 p.

Mansfield, W. C., 1927, The Miocene stratigraphy of Virginia, based upon the study of the faunas: George Washington University, unpub. Ph.D thesis, $156 \mathrm{p}$.

1928, New fossil mollusks from the Miocene of Virginia and North Carolina, with a brief outline of the divisions of the Chesapeake group: U.S. National Museum Proceedings, v. 74, art. 14, 11 p. 1929 .

1931, The Miocene stratigraphy of Virginia based upon the study of faunas: George Washington University Bulletin, Summaries of Doctoral Theses 1925-1928, p. 91-96.

1943, Stratigraphy of the Miocene of Virginia and the Miocene and Pliocene of North Carolina, in Gardner, Julia, Mollusca from the Miocene and lower Pliocene of Virginia and North Carolina: Pt. 1, Pelecypoda: U.S. Geological Survey Professional Paper 199-A, p. 1-19.

McGee, W. J., 1888, Three formations of the Middle Atlantic slope: American Journal Science, ser. 3, 35, p. 120-143, 328-330, 367-388, 448-466.

1891, The Geology of Washington and vicinity, in Guide to Washington and its scientific institutions, prepared by the local committee for the International Congress of Geologists, 5th session, Washington, 1891: pp. 38-64.

Olsson, Axel, 1917, The Murfreesboro stage of our east coast Miocene: Bulletins of American Paleontology, v. 5, no. 28, 11 p. (v. 5, p. 155-163).

Teifke, R. H., 1973, Stratigraphic units of the lower Cretaceous through Miocene series: Virginia Division of Mineral Resources Bulletin 83, part 1, p. 1-78.

Weems, R. E., 1968, The Virginia Miocene: Randolph-Macon College Sci. Mag., v. 3, p. 15, 16.

Wilmarth, M. G., 1957, Lexicon of Geologic Names of the United States: U.S. Geological Survey Bulletin 896, pt. 1, p. 11281129. 
Figure 1. Isognomon sp.

Right valve of a nearly complete specimen (USNM 258347), from Cobham Wharf, Va. (loc. 28) (USGS loc. 26052), length $150.3 \mathrm{~mm}$.

2. Ecphora sp.

Apertural view of specimen (USNM. 258348), from just above Sunken Meadow Creek on the James River, Va. (loc. 17) (USGS loc. 26041), height $74.4 \mathrm{~mm}$.

3. Mercenaria sp.

Left valve of specimen (USNM 258349), from just above Sunken Meadow Creek on the James River, Va. (loc. 17) (USGS loc. 26041), length $93.5 \mathrm{~mm}$, height $75.9 \mathrm{~mm}$.

4. Glycymer is virginiae (Dall, 1898)

Left valve of specimen (USNM 258350), from Cobham Wharf, Va. (loc. 28) (USGS loc. 26052), length $60.5 \mathrm{~mm}$, height $65.1 \mathrm{~mm}$.

5. Scapharca virginiae (Dall, 1898)

Right valve of specimen (USNM 258351) from just above Sunken Meadow Creek on the James River, Va. (loc. 17) (USGS loc. 26041), length $82.2 \mathrm{~mm}$, height $57.3 \mathrm{~mm}$.

6. Lirophora dalli (Olsson, 1914)

Right valve of specimen (USNM 258352) from Cobham Wharf, Va. (loc. 28) (USGS loc. 26052), length $19.3 \mathrm{~mm}$, height $17.2 \mathrm{~mm}$.

7. Scapharca clisea (Dall, 1898)

Left vaIve of specimen (USNM 258353), from just above Sunken Meadow Creek on the James River Va. (loc. 17) (USGS loc. 26041), length $42.7 \mathrm{~mm}$, height $44.1 \mathrm{~mm}$.

8. Glossus fraterna (Say, 1824)

Left valve of specimen (USNM 258354), from just below the mouth of Upper Chippokes Creek on the James River, Va. (loc. 18) (USGS loc. 26042), length $87.3 \mathrm{~mm}$, height $80.2 \mathrm{~mm}$.

9. Euloxa latisulcata (Conrad, 1839)

Left valve of an incomplete specimen (USNM 258355), from just below the mouth of Upper Chippokes Creek on the James River, Va. (loc. 18) (USGS loc. 26042), approx. length $15.0 \mathrm{~mm}$, approx. height $13.1 \mathrm{~mm}$.

10. Ostrea sp.

Left valve of specimen (USNM 258356), from just above Sunken Meadow Creek on the James River, Va. (loc. 17) (USGS loc. 26041), length $97.7 \mathrm{~mm}$, height $111.9 \mathrm{~mm}$.

11. Turritella sp. aff. T. plebeia (Say, 1824)

Apertural view of incomplete specimen (USNM 258357), from just below the mouth of Upper Chippokes Creek on the James River, Va. (loc. 18) (USGS loc. 26042), height 24.3 $\mathrm{mm}$.

12. Chesapecten middlesexensis (Mansfield, 1936)

Right valve of specimen (USNM 258358), from just above Sunken Meadow Creek on the James River, Va. (loc. 17) (USGS loc. 26041), length $98.8 \mathrm{~mm}$, height $91.4 \mathrm{~mm}$. 

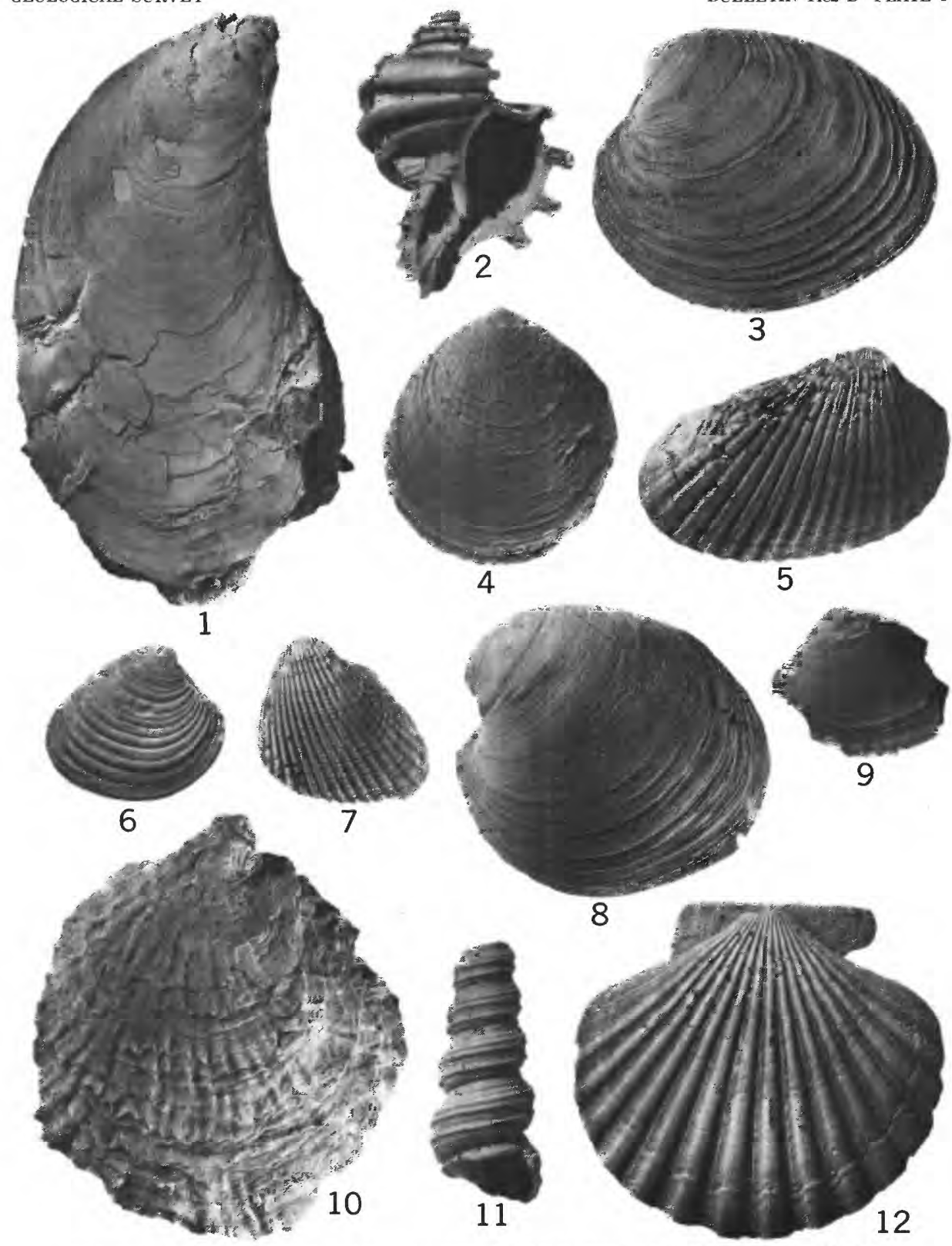

COMMON BIVALVES AND GASTROPODS FROM THE CLAREMONT MANOR MEMBER OF THE EASTOVER FORMATION 


\section{PLATE 2}

Figure 1. Placopecten princepoides (Emmons, 1858)

Right valve of a topotype specimen (USNM 258359), from just above Murfreesboro, N.C., on the Meherrin River (loc. 29) (USGS loc. 26053), length $155.8 \mathrm{~mm}$, height $140.0 \mathrm{~mm}$.

2, 3. Scapharea carolinensis (Dall, 1897)

2. Right valve of a complete specimen (USNM 258360), from $2.7 \mathrm{~km}$ below Bowlers Wharf on the Rappahannock River, Va. (loc. 2) (USGS loc. 26026), length $44.9 \mathrm{~mm}$, height 46.7 $\mathrm{mm}$.

3. Left valve of same specimen (USNM 258360), length 44.7 $\mathrm{mm}$, height $46.8 \mathrm{~mm}$.

4. Glycymer is sp.

Right valve of specimen (USNM 258361), from Cobham Wharf, Va. (loc. 28) (USGS loc. 26052), length $29.2 \mathrm{~mm}$. height $27.9 \mathrm{~mm}$.

5. "Pecten" urbannaensis (Mansfield, 1928)

Right valve of specimen (USNM 258362), from Cobham Wharf, Va. (loc. 28) (USGS loc. 26052), length $77.3 \mathrm{~mm}$, height $73.5 \mathrm{~mm}$.

6. Chesapecten middlesexensis (Mansfield, 1936)

Right valve of specimen (USNM 258363) from Urbanna Creek, Middlesex County, Va. (loc. 5) (USGS loc. 26029 length $115.2 \mathrm{~mm}$, height $110.1 \mathrm{~mm}$. 


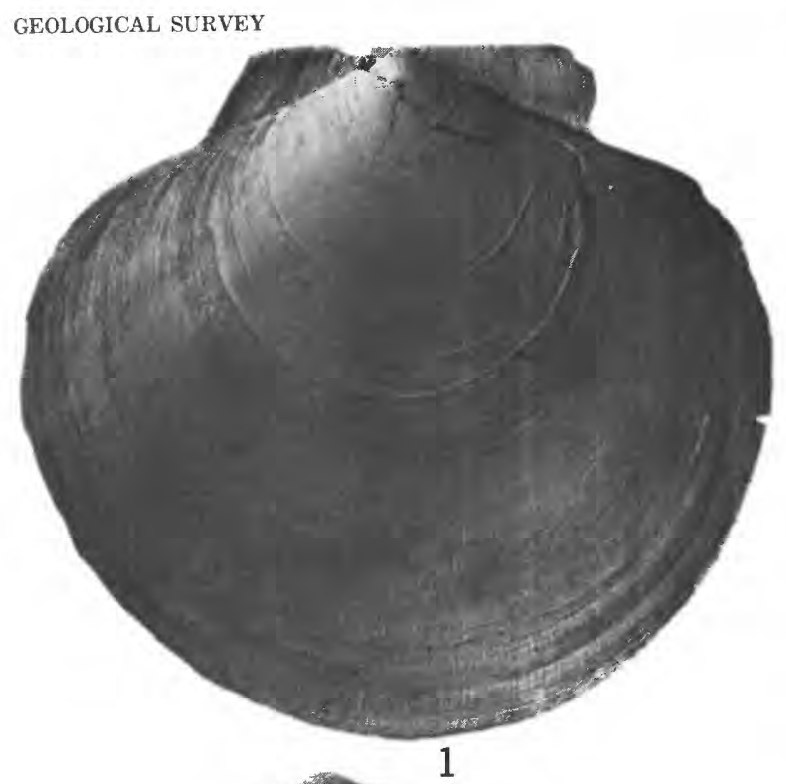

BULLETIN 1482-D PLATE 2
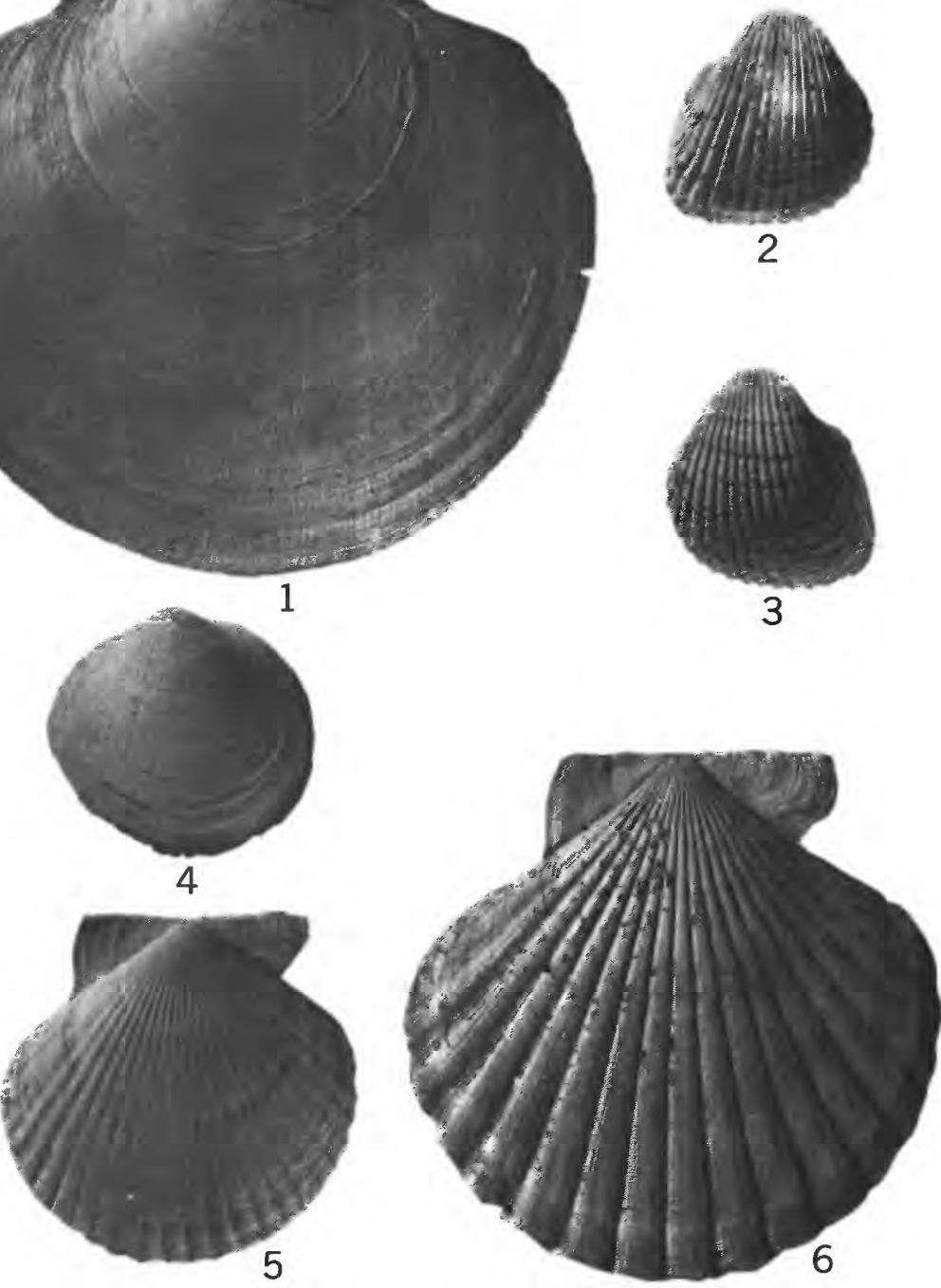

COMMON BIVALVES FROM THE COBHAM BAY MEMBER OF THE EASTOVER FORMATION 


\section{PLATE 3}

Figure 1. Isognomon sp.

Right valve of a nearly complete specimen (USNM 258364), from Burhans Wharf on the Rappahannock River, Va. (loc. 38) (USGS loc. 26062), length $225.0 \mathrm{~mm}$.

2. Astarte rappahannockensis (Gardner, 1943)

Left valve of specimen (USNM 258365), from just below Sunken Meadow Creek on the James River, Va. (loc.7), (USGS loc. 26031), length $21.9 \mathrm{~mm}$, height $19.8 \mathrm{~mm}$.

3. Euloxa latisulcata (Conrad, 1839)

Left valve of specimen (USNM 258366), from Cobham Wharf, Va. (loc. 28) (USGS loc. 26052), length $20.9 \mathrm{~mm}$, height $18.9 \mathrm{~mm}$.

4. Mercenaria sp.

Left valve of specimen (USNM 258367), from Urbanna Creek just above Urbanna, Va. (Ioc. 5) (USGS loc. 26029) length $75.5 \mathrm{~mm}$, height $63.3 \mathrm{~mm}$.

5,6 . Spisula rappahannockensis (Gardner, 1943)

5. Left valve of specimen (USNM 258368), from $2.7 \mathrm{~km}$ below Bowlers Wharf on the Rappahannock River, Va. (loc. 2) (USGS loc. 26026), length $27.2 \mathrm{~mm}$, height $18.8 \mathrm{~mm}$.

6. Interior of right valve of specimen (USNM 258369), from same locality as that shown in fig. 5 , length $28.0 \mathrm{~mm}$, height $19.0 \mathrm{~mm}$.

7. Ostrea compressirostra (Say, 1824)

Left valve of specimen (USNM 258370), from Cobham Wharf, Va. (loc. 28) (USGS loc. 26052), length 90.1 $\mathrm{mm}$, height $106.8 \mathrm{~mm}$. 


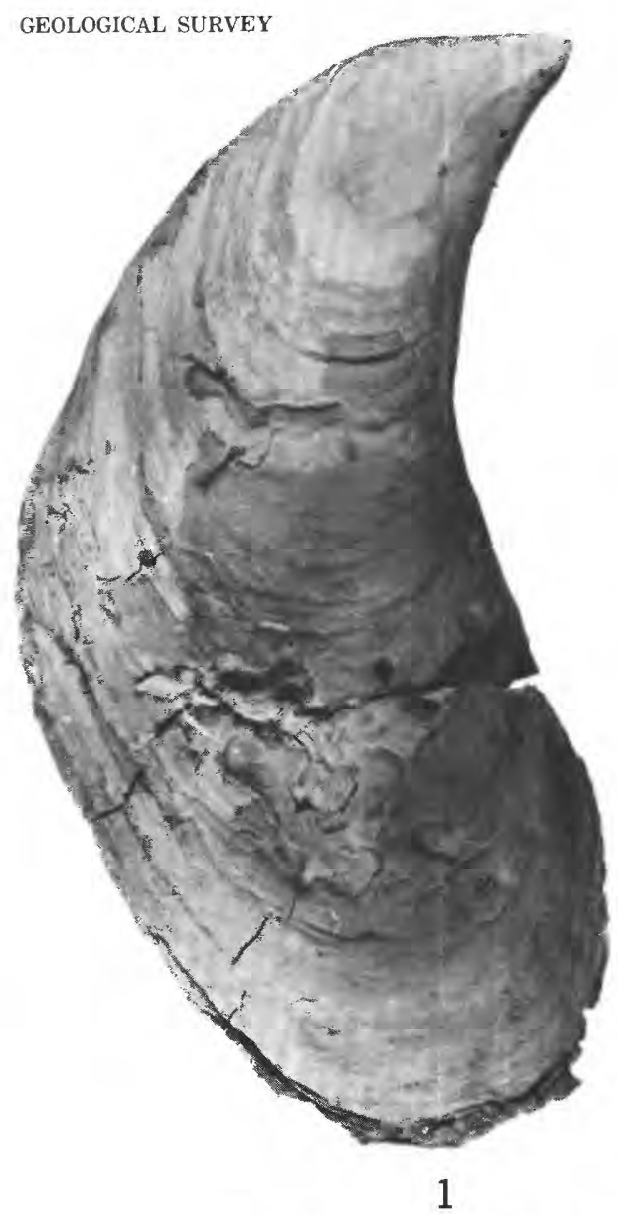

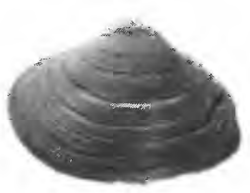

5

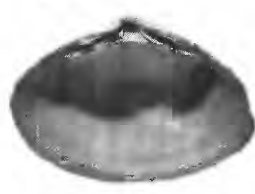

6
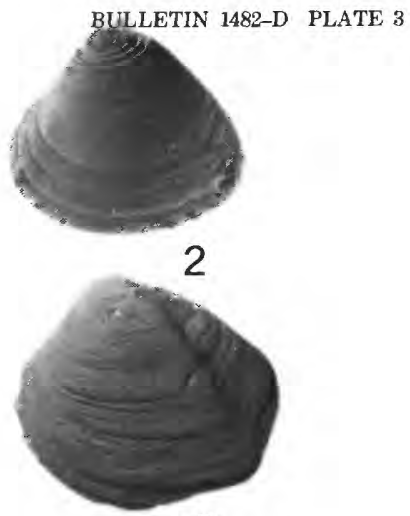

3
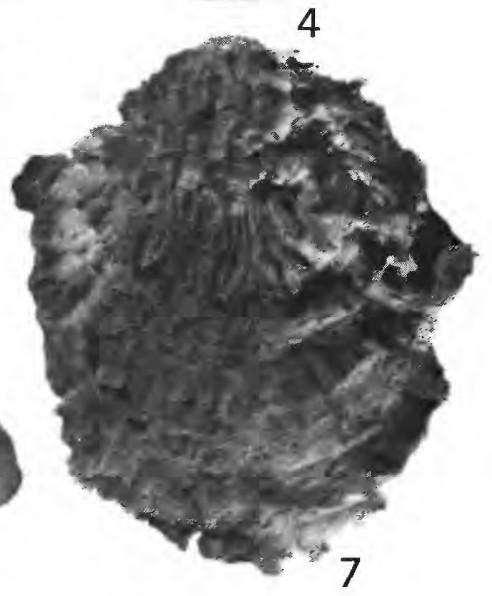

COMMON BIVALVES FROM THE COBHAM BAY MEMBER OF THE EASTOVER FORMATION 


\section{PLATE 4}

Figure 1. Placopecten clintonius (Say. 1824)

Right valve of specimen (USNM 258371), from just below Sunken Meadow Creek on the James River, Va. (loc. 7) (USGS loc. 26031), length $129.0 \mathrm{~mm}$, height $127.3 \mathrm{~mm}$.

2. Chesapecten jeffersonius (Say, 1824)

Left valve of specimen (USNM 258372) from $1.0 \mathrm{~km}$ below Kingsmill Wharf on the James River, Va. (loc. 81) (USGS loc. 26105 ), length $98.6 \mathrm{~mm}$, height $91.1 \mathrm{~mm}$.

3, 4. Pyenodonte sp.

Exterior and interior views of the left valve of a specimen (USNM 258373), from $1 \mathrm{~km}$ below Eastover on the James River, Va. (loc. 86) (USGS loc. 26110), length $63.5 \mathrm{~mm}$, height $67.1 \mathrm{~mm}$.

5. Ostrea compressirostra (Say, 1824)

Left valve of specimen (USNMN 258374) from just below Sunken Meadow Creek on the James River, Va. (loc. 7) (USGS loc. 26031), length $83.2 \mathrm{~mm}$, height $77.8 \mathrm{~mm}$.

6. Busycon maximum (Conrad, 1839)

Apertural view of incomplete specimen (USNM 258375), from Martiau on the Piankatank River, Middlesex County, Va. (loc. 82) (USGS loc. 26106), length?, height $92.1 \mathrm{~mm}$.

7. Panopea reflexa Say, 1824

Left valve of specimen (USNM 258376), from just below Sunken Meadow Creek on the James River, Va. (loc. 7) (USGS loc. 26031), length $124.4 \mathrm{~mm}$, height $74.0 \mathrm{~mm}$.

8. Mercenaria sp.

Right valve of specimen, (USNM 258377), from just below Sunken Meadow Creek on the James River, Va. (loc.7) (USGS loc. 26031), length $108.5 \mathrm{~m}$, height $94.0 \mathrm{~mm}$.

9. Astarte deltoidea (Gardner, 1943)

Right valve of specimen (USNM 258379), from just below Sunken Meadow Creek on the James River, Va. (loc. 7) (USGS loc. 26031), length $24.2 \mathrm{~mm}$, height $25.6 \mathrm{~mm}$.

10. Astarte vaginulata (Dall, 1903)

Right valve of specimen (USNM 258379) from just below Sunken Meadow Creek on the James River, Va. (loc. 7) (USGS loc. 26031), length $25.3 \mathrm{~mm}$, height $22.0 \mathrm{~mm}$.

11. Eephora quadricostata (Say, 1824)

Apertural view of specimen (USNM 258380), from Haynes Mill, Gloucester Co., Va. (loc. 87) (USGS Ioc.26111), height $119.8 \mathrm{~mm}$. 


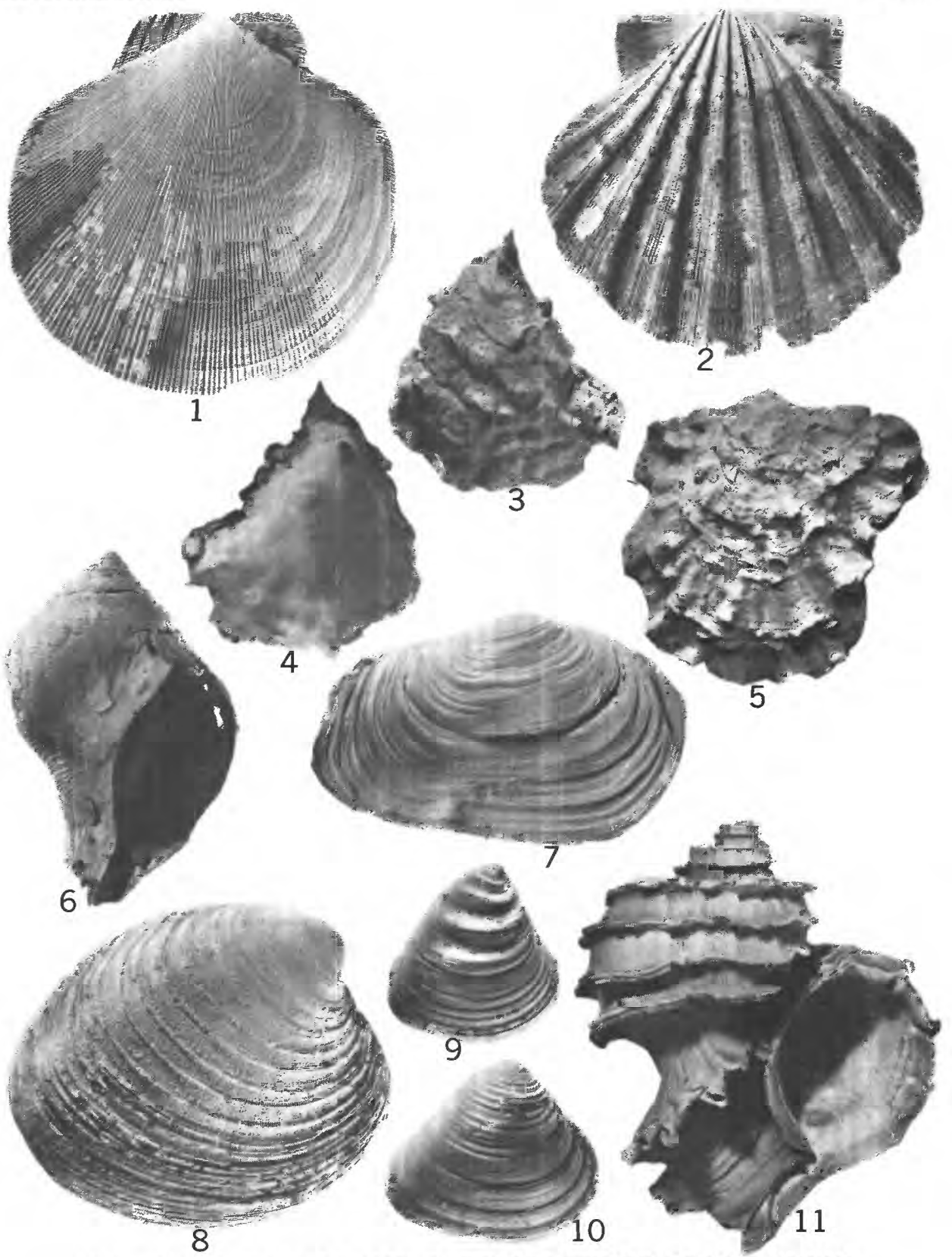

COMMON BIVALVES AND GASTROPODS FROM THE SUNKEN MEADOW MEMBER OF THE YORKTOWN FORMATION 
Figure 1. Chesapecten septenarius (Say, 1824)

Right valve of specimen (USNM 258381) from Lieutenant Run in Petersburg, Va. (loc. 43) (USGS loc. 26067), length $68.8 \mathrm{~mm}$, height $66.3 \mathrm{~mm}$.

2. Chesapecten madisonius (Say, 1824)

Right valve of specimen (USNM 258381) from Lieutenant Run in Petersburg, Va. (loc. 43) (USGS loc. 26067), length $68.8 \mathrm{~mm}$, height $66.3 \mathrm{~mm}$.

3. Fusinus exilus (Conrad, 1832)

Apertural view of specimen (USNM 258383), from $1.0 \mathrm{~km}$ below Morgarts Beach on the James River, Va. (loc. 55) (USGS loc. 26079), height $50.3 \mathrm{~mm}$.

4. Busycon maximum (Conrad, 1839)

Apertural view of specimen (USNM 258384), from Rices Borrow Pit in Hampton, Va. (loc. 88) (USGS loc. 26112), height $260.0 \mathrm{~mm}$.

5. Ostrea raveneliana Tuomey and Holmes, 1855

Left valve of specimen (USNM 258385 ), from $1.0 \mathrm{~km}$ below Morgarts Beach on the James River, Va.(Ioc. 55) (USGS loc. 26079), length $102.5 \mathrm{~mm}$, height $114.3 \mathrm{~mm}$.

6. Ostrea sculpturata Conrad, $\mathbf{1 8 4 0}$

Left valve of specimen (USNM 258386), from Rices Borrow Pit in Hampton, Va. (loc. 88) (USGS loc. 26112), length 42.1 $\mathrm{mm}$, height $57.2 \mathrm{~mm}$.

7. Astarte undulata (Say 1824)

Right valve of specimen (USNM 258387), from $1.0 \mathrm{~km}$ above Morgarts Beach on the James River, Va. (loc. 89) (USGS loc. 26113), length $28.4 \mathrm{~mm}$, height $26.4 \mathrm{~mm}$.

8. Glycymer is tuomeyi (Dall, 1898)

Right valve of specimen (USNM 258388 from Morgarts Beach on the James River, Va.(loc. 90) (USGS loc. 26114), length $35.5 \mathrm{~mm}$ height $31.8 \mathrm{~mm}$.

9. Glycymer is americana (DeFrance, 1826)

Right valve of specimen (USNM 258389), from Morgarts Beach on the James River, Va. (loc. 90) (USGS loc. 26114), length $60.7 \mathrm{~mm}$, height $55.6 \mathrm{~mm}$.

10. Mercenaria tridacnoides rileyi (Conrad,1838)

Right valve of specimen (USNM 258390), from Lieutenant Run in Petersburg, Va. (loc. 43) (USGS loc. 26067), length $94.0 \mathrm{~mm}$, height $70.2 \mathrm{~mm}$

11, 12. Pseudochama corticosa (Conrad,1833)

Exterior and interior views of the right valve of a specimen (USNM 258391), from Morgarts each on the James, Va. (loc.90) (USGS loc. 26114), River, length 46.1 $\mathrm{mm}$, height $51.5 \mathrm{~mm}$.

13. Astarte concentrica (Conrad, 1834)

Right valve of specimen (USNM 258392), from Lieutenant Run in Petersburg, Va. (loc. 43) (USGS loc. 26067), length $22.6 \mathrm{~mm}$, height $20.5 \mathrm{~mm}$.

14. Mulinia congesta (Conrad,1833)

Right valve of specimen (USNM 258393), from Waverly, Sussex County, Va. (loc. 91) (USGS loc. 26115), length 17.4 $\mathrm{mm}$, height $12.9 \mathrm{~mm}$.

15. Mercenaria tridacnoides (Lamarck, 1818)

Right valve of specimen (USNM 258394), from Lieutenant Run in Petersburg, Va. (loc. 43) (USGS loc. 26067), length $106.1 \mathrm{~mm}$, height $83.8 \mathrm{~mm}$.

16. Planicardium virginianum (Conrad, 1839)

Left valve of specimen (USNM 258395), from Rices Borrow Pit in Hampton, Va. (loc. 88) (USGS loc. 26112), length 95.9 $\mathrm{mm}$, height $120.0 \mathrm{~mm}$. 

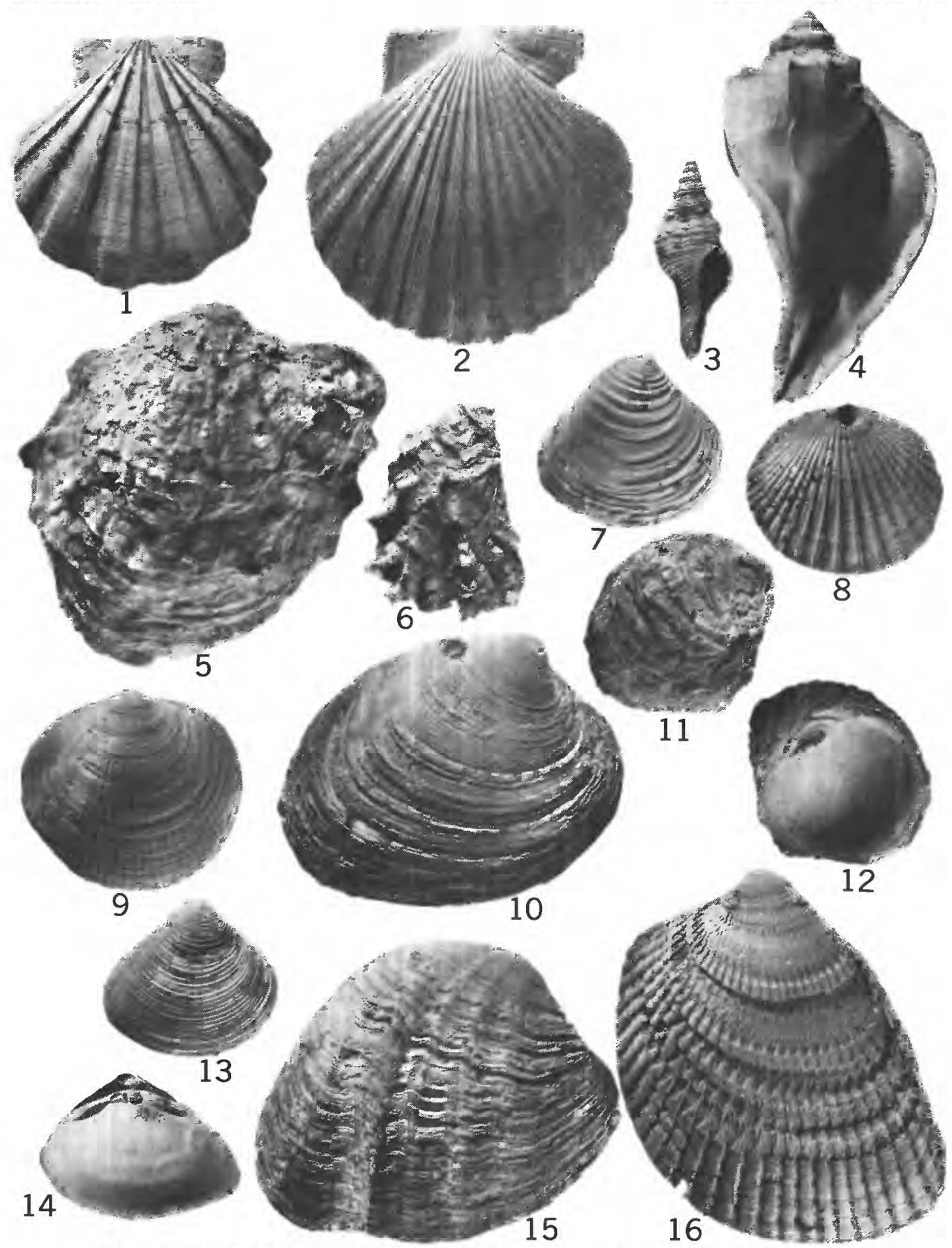

COMMON BIVALVES AND GASTROPODS FROM THE RUSHMERE, MORGARTS BEACH, AND MOORE HOUSE MEMBERS

OF THE YORKTOWN FORMATION 


